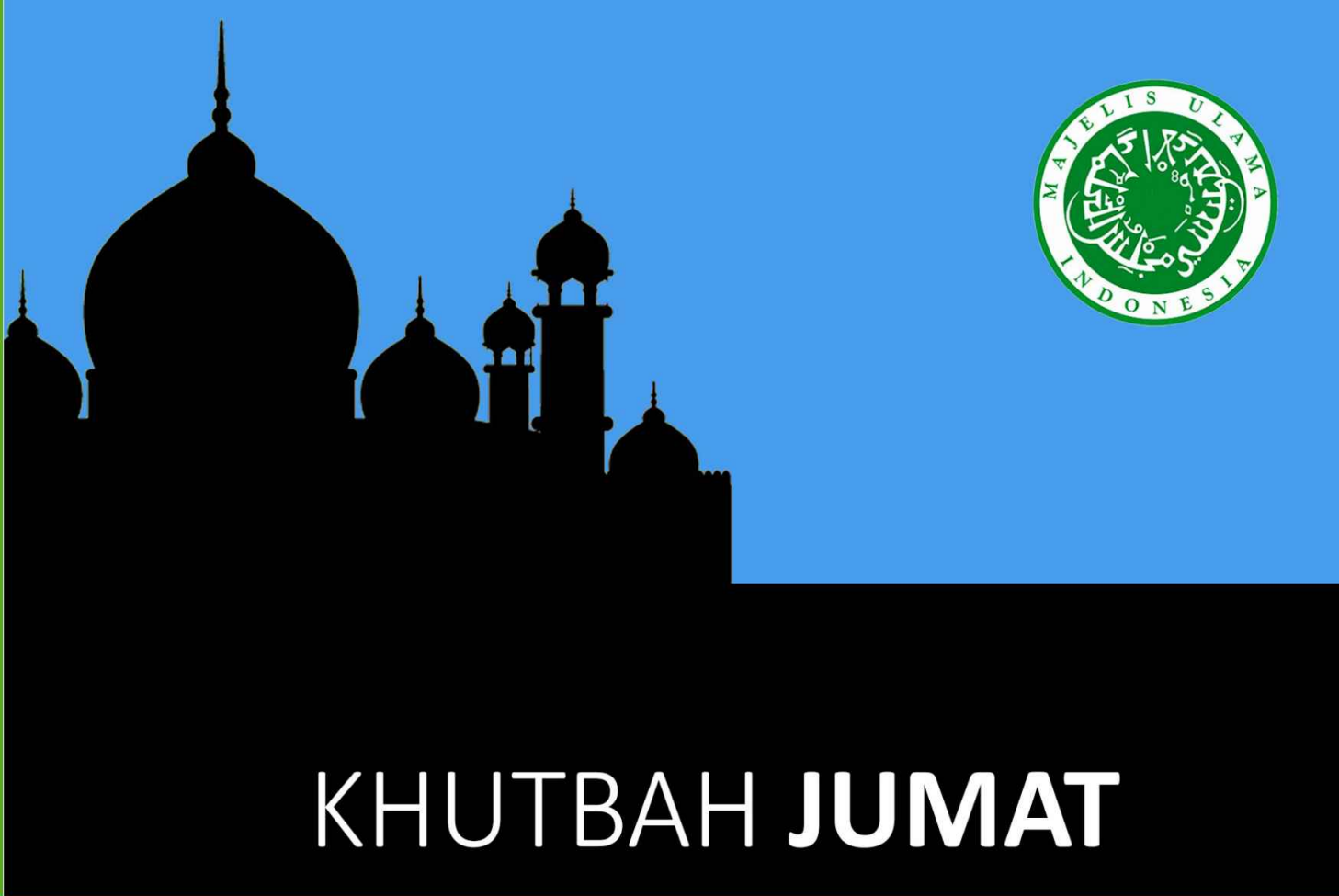

\title{
PELESTARIAN SATWA LANGKA UNTUK KESEIMBANGAN EKOSISTEM
}
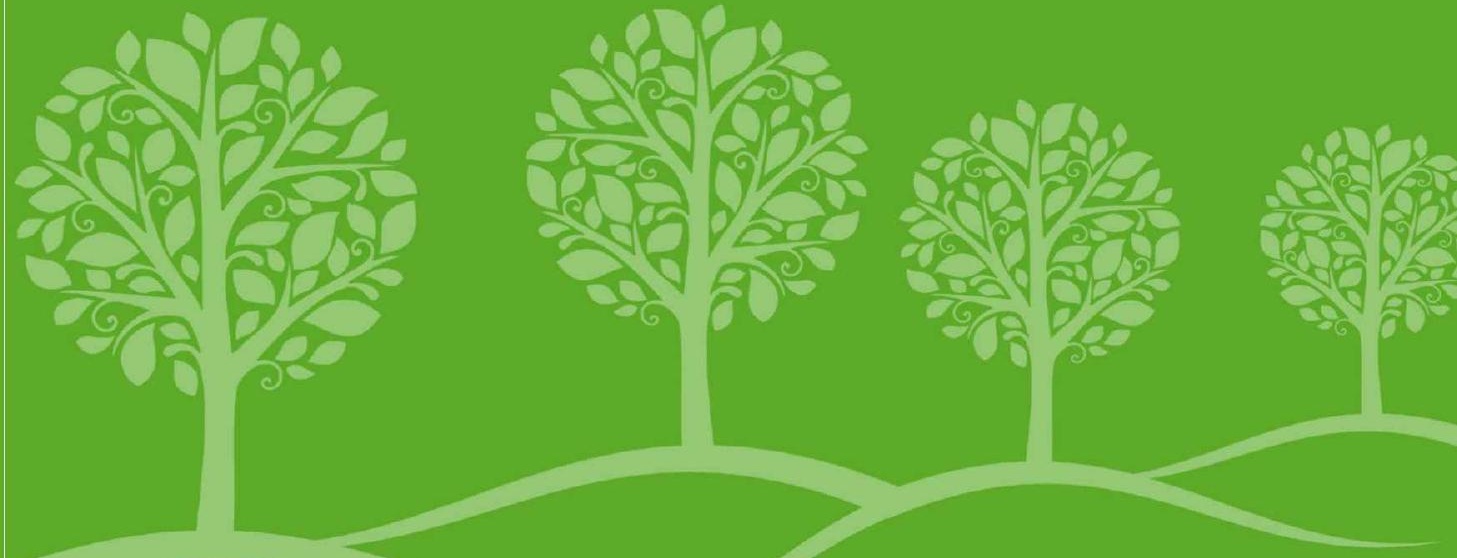



\section{KHUTBAH JUMAT PELESTARIAN SATWA LANGKA UNTUK KESEIMBANGAN EKOSISTEM}


Judul:

Khutbah Jumat Pelestarian Satwa Langka untuk Keseimbangan Ekosistem

Diterbitkan oleh:

Majelis Ulama Indonesia

ISBN No: 978-602-0819-38-9

Hak Cipta Dilindungi oleh Undang Undang

(C) Sya'ban 1438H / Mei 2017

Penulis:

Dr. Hayu S. Prabowo, M.Hum

Dr. Fachruddin Mangunjaya,MSi

Drs. Shalahuddin Al Ayyubi,MSi

Mifta Huda, S.Pd.I, M.E.Sy

Abdurrahman Hilabi, S.Pd.I, M.Pd.I

Editor:

KH Arwani Faisol 


\section{cீ人ैa? \\ KATA PENGANTAR \\ KETUA UMUM MAJELIS ULAMA \\ INDONESIA}

Assalamu'alaikum Warahmatullah Wabarakaatuh

Alhamdulillahi wahdah, as-shalatu was-salamu 'ala man la nabiyya ba'dah, sayyidina wa maulana Muhammadin Ibni Abdillah, wa 'ala alihi wa ashhabihi wa man tabi'ahum bi-ihsanin ila yaumil qiyamah. Amma ba'du.

Puji syukur ke hadirat Allah SWT, Tuhan sekalian alam, yang menjadikan Indonesia sebagai sebuah negara dengan keanekaragaman satwa yang terbanyak di dunia, hingga dijuluki sebagai Megadiversity Country. Karunia besar tersebut harus dijaga dengan baik, di antaranya melalui upaya perlindungan satwa untuk mengurangi angka kepunahannya di Indonesia. Umat Islam sebagai bagian terbesar penduduk di negeri ini mempunyai tanggungjawab lebih besar dalam mengemban amanah melindungi keanekaragaman satwa tersebut.

Sesungguhnya semenjak tahun 1990-an, berbagai elemen masyarakat telah mulai menyuarakan pentingnya perlindungan terhadap satwa. Namun hal itu belum berlaku dalam skala massif. Di antara penyebabnya adalah kurangnya pengetahuan, kesadaran dan kepedulian masyarakat, yang kemudian menjadi penyebab utama terjadinya kepunahan satwa di Indonesia. Hal tersebut tercermin dari masih maraknya perburuan dan perdagangan satwa. Adanya anggapan bahwa semakin langka satwa maka akan semakin mahal harganya, menjadikan praktek perburuan dan perdagangan sulit untuk diakhiri. Padahal setiap satwa memiliki peranan dalam silkus rantai makanan. Jika satu spesies satwa diburu dan mengalami kepunahan dapat berakibat pada rusaknya ekosistem 
satwa. Rusaknya siklus rantai makanan ini secara berkelanjutkan mengakibatkan kepunahan spesies lainnya.

Banyak firman Allah SWT yang memperlihatkan bahwa semua makhluk hidup mempunyai peranan atau fungsi khusus yang tidak dapat digantikan oleh makhluk lainnya untuk menjaga keseimbangan lingkungan hidup. Oleh karena itu, manusia harus mempunyai kepedulian dan perhatian kepada makhluk-makhluk lain sebagai komponen-komponen yang menunjang serta melestarikan kehidupan ini sebagaimana manusia itu memperhatikan dirinya sendiri.

Di antara upaya yang bisa dilakukan untuk menumbuhkan pengetahuan, kesadaran dan kepedulian masyarakat dalam melindungi satwa adalah dengan menggunakan pendekatan keagamaan. Upaya menumbuhkan kesadaran melalui pendekatan keagamaan dalam banyak hal telah terbukti lebih efektif. Kepedulian dan kesadaran yang didasari oleh keyakinan keagamaan diyakini memiliki pijakan yang lebih kuat dan permanen, serta lebih konsisten dalam implementasinya.

Di antara media yang dapat digunakan untuk melaksanakan hal itu adalah melalui mimbar khutbah, terutama khutbah Jumat. Setiap muslim laki-laki baligh yang tidak sedang ada udzur syar'i diwajibkan untuk ikut shalat Jumat, dan khutbah Jumat merupakan bagian dari rangkaian shalat jumat tersebut. Karena itu, materi khutbah Jumat yang mengangkat topik tentang pandangan ajaran Islam pada perlindungan satwa dipandang sangat strategis untuk menumbuhkan kesadaran umat Islam yang kemudian pada saatnya akan tumbuh kepedulian terhadap pentingnya perlindungan satwa. Kumpulan khutbah Jumat Tentang "Pelestarian Satwa Langka untuk Menjaga Keseimbangan Ekosistem" ini memberikan arahan bagaimana dan apa yang seharusnya dilakukan oleh manusia agar eksistensi satwa dapat terjaga untuk seterusnya. Punahnya satwa 
akan berdampak buruk secara langsung pada kehidupan manusia. Kumpulan khutbah Jumat ini juga memberikan petunjuk bagaimana sesungguhnya keindahan ajaran Islam yang mendorong umat manusia untuk berperilaku baik (al-ihsan) kepada satwa. Kumpulan khutbah Jumat ini layak untuk dibaca dan dijadikan referensi bagi para khathib dalam menyampaikan khutbahnya, dan bagi umat Islam, sehingga tumbuh kesadaran untuk menjaga dan melestarikan satwa.

Atas terbitnya buku Kumpulan Khutbah Jumat Tentang "Pelestarian Satwa Langka untuk Menjaga Keseimbangan Ekosistem" ini Majelis Ulama Indonesia mengucapkan terima kasih yang sebesar-besarnya kepada semua pihak yang berkenan dalam membantu tersusunnya dan didakwahkannya isi kumpulan khutbah jumat ini, Terutama Pusat Pengajian Islam (PPI) Universitas Nasional dan WWF Indonesia yang telah bekerjasama dalam penyusunan kumpulan khutbah jumat ini. Semoga apa yang telah dilakukan tersebut dicatat oleh Allah sebagai amal baik.

Wassalamu'alaikum Warahmatullah Wabarakaatuh

Jakarta, 28 Rajab 1408 H/ 25 April 2017 M

DEWAN PIMPINAN

MAJELIS ULAMA INDONESIA

Ketua Umum,

DR. KH. MA'RUF AMIN 


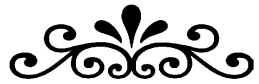 \\ DAFTAR ISI}

Judul Khutbah

Halaman

Akhlak Memelihara Satwa

$7-13$

Perdagangan Satwa Dan Pemunahan Satwa

Adalah Haram

Manfaat Melestarikan Satwa Langka

$23-29$

Melindungi Dan Melestarikan Alam Termasuk Satwa

$30-35$

Melindungi Satwa Dari Kepunahan

$36-43$

Memelihara Satwa Dan Memperdagangkannya

$44-51$

Mengasihi Makhluk Allah Adalah Ibadah

$52-61$

Seluruh Makhluk Termasuk Satwa Bertasbih

$62-68$

Pelestarian Alam dan Satwa

$69-75$

Mengapa Allah Menciptakan Makhluk Selain Manusia ...

$76-83$

Mensyukuri Dan Merawat Alam Termasuk Satwa

$84-90$

Akhlak Memanfaatkan Sumber Daya Alam

Termasuk Satwa

$91-97$ 


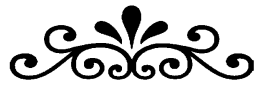 \\ AKHLAK MEMELIHARA SATWA \\ Khuthbah 1}

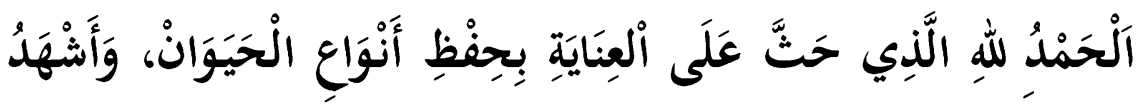

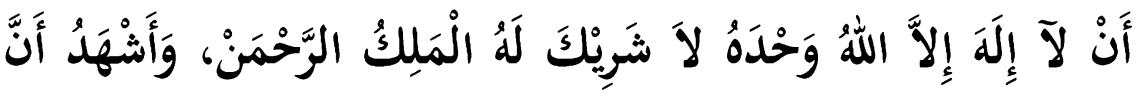

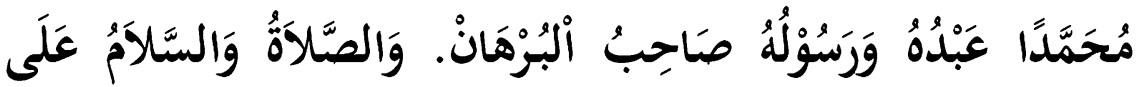

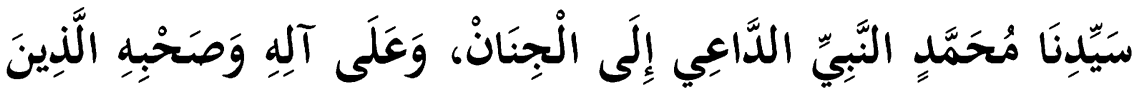

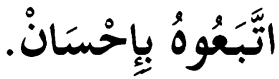

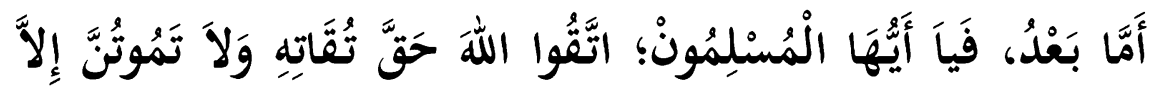

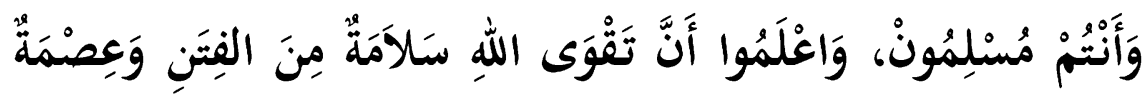
مِنَ المِحَنِ.

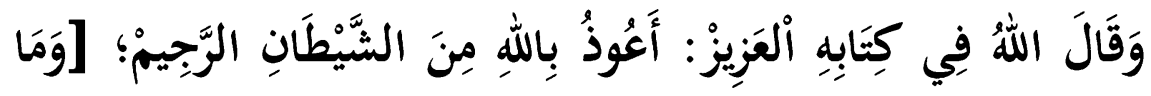

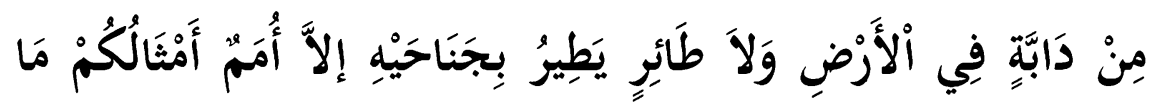

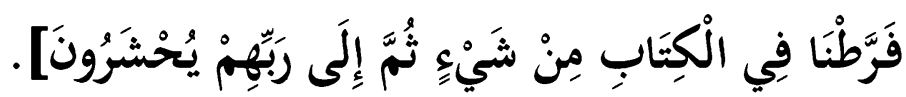

Ma’asyiral Muslimin, Rahimakumullah.

Syari'at Islam mengajarkan akhlak mulia tentang penghormatan kepada makhluk hidup, baik manusia maupun hewan. Dalam peperangan, wanita dan anak-anak harus dilindungi dan jangan sampai terbunuh. Membunuh manusia tanpa alasan yang benar 
(haq) digambarkan seperti membunuh seluruh manusia. Allah SWT. berfirman di dalam Surat Al-Maidah: 32:

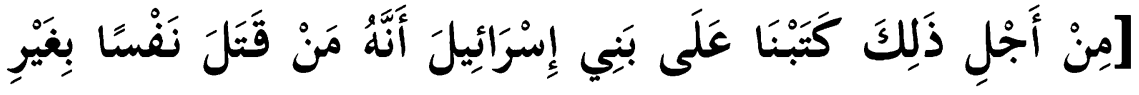

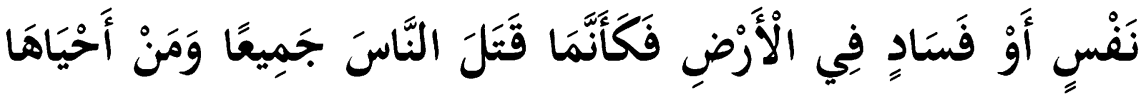

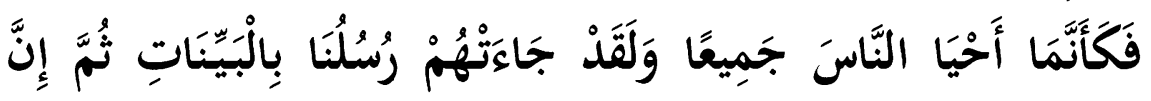 كَثِيرًا مِنْهُمْ بَعْدَ ذَلِكَ فِي الْأَرْضِ لَمُسْرِفُونَ] - (المائدة: 32)}

Oleh karena itu Kami tetapkan (suatu hukum) bagi Bani Israil, bahwa barangsiapa yang membunuh seorang manusia, bukan karena orang itu (membunuh) orang lain, atau bukan karena membuat kerusakan di muka bumi, maka seakan-akan dia telah membunuh manusia seluruhnya. Dan barangsiapa yang memelihara kehidupan seorang manusia, maka seolah-olah dia telah memelihara kehidupan manusia semuanya. Dan sesungguhnya telah datang kepada mereka rasul-rasul Kami dengan (membawa) keterangan-keterangan yang jelas, kemudian banyak di antara mereka sesudah itu sungguh-sungguh melampaui batas dalam berbuat kerusakan di muka bumi. (Qs. Al-Maidah [5]: 32)

Dalam hadits riwayat dari 'Abdullah bin 'Umar r.a, ia berkata:

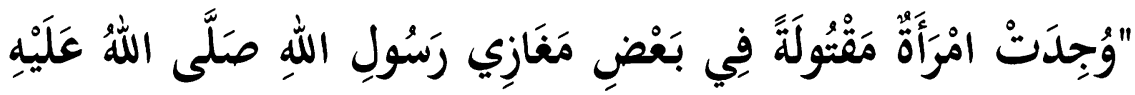

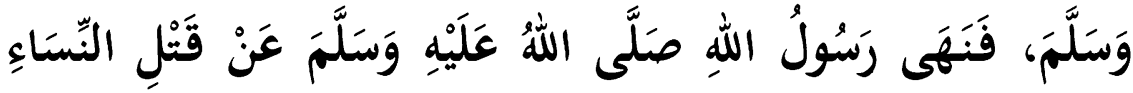
وَالصِّبْيَانِ". - - رواه البخاري ومسلم

"Seorang wanita ditemukan terbunuh dalam sebuah peperangan bersama Rasulullah SAW. Kemudian beliau melarang membunuh kaum wanita dan anak-anak dalam berperang". (HR Bukhari [3015] dan Muslim [1744]). 
Dalam hadits riwayat lain disebutkan, bahwa Rasulullah SAW. mengecam keras pembunuhan terhadap wanita dan anak-anak. HR. Bukhari [3014] dan Muslim [1744]). Dalam suatu hadist yang lebih lengkap diriwayatkan sebagai berikut:

\section{عَنْ يَحْيَى بْنِ سَعِيْدِ أَنَّ أَباً بَكْرِ الصِّدِّيقِ رضي الله عنه بَعَثَ جُيُوْشَا إلََلى الشَّام، فَخَرَجَ يَمْشِى مَعَ يَزِيْدَ بْنِ اَبِى سُفْيَانَ، وَكَانَ

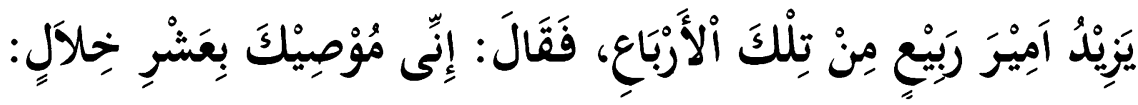

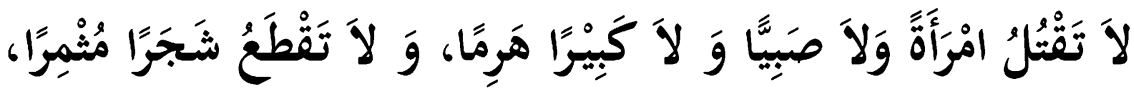

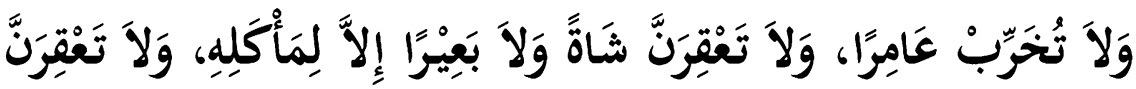

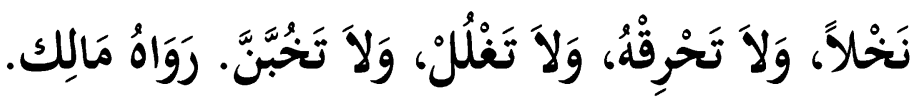

Dari Yahya bin Sa'id, sesungguhnya Abu Bakar Ash-Shiddiq ra. pernah mengutus tentara ke Syam, lalu beliau keluar sambil berjalan kaki bersama Yazid bin Abu Sufyan, sedang Yazid ketika itu adalah kepala seperempat dari (pasukan-pasukan) yang dibagi empat itu, abu Bakar berkata, "Sesungguhnya aku berwasiat kepadamu dengan sepuluh hal: 1. Jangan membunuh perempuan, 2. Jangan membunuh anak-anak, 3. Jangan membunuh orang tua yang sudah tak berdaya, 4. Jangan menebang pohon yang sedang berbuah, 5. Jangan merobohkan bangunan, 6. Jangan menyembelih kambing dan unta kecuali untuk dimakan, 7. Jangan merusak pohon kurma, 8. Jangan membakar pohon kurma, 9. Jangan berkhianat, 10. Jangan menjadi pengecut". [HR. Malik]

Syari'at Islam mengajarkan pula tata cara berburu binatang secara baik sebagai bentuk penghormatan kepada binatang. Dalam berburu harus menggunakan peralatan yang aman dan tidak mencederai hewan buruan. Penggunaan alat untuk menangkapnya yang dapat mencederainya merupakan tindakan penganiayaan yang membawa 
malapetaka dan dapat berakhir dengan kematian. Sehubungan itu, Rasulullah SAW. melarang keras mengikat hewan untuk permainan. Hewan merupakan sesama makhluk Allah SWT. yang harus diperlakukan dengan baik dalam segala hal. Apabila terdapat hewan yang perlu dibunuh karena suatu sebab, maka harus dilakukan dengan cara yang baik tanpa menganiayanya. Demikian pula ketika perlu menyembelihnya, harus dilakukan secara baik dengan menyiapakan pisau yang tajam, dan menjadikannya tenang tanpa rasa kesakitan. Rasulullah SAW. bersabda:

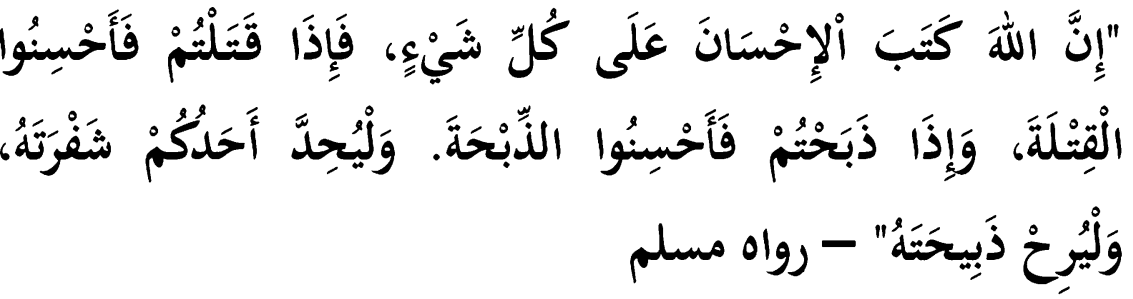

"Sesungguhnya Allah SWT. telah mewajibkan berbuat baik terhadap segala sesuatu, jika kamu membunuh maka bunuhlah dengan cara yang baik, dan jika kamu menyembelih maka sembelihlah dengan cara yang baik. Tajamkan mata pisau dan tenangkanlah hewan sembelihanmu". (HR. Muslim).

Berbuat baik dalam segala hal kepada hewan sebagaimana dalam hadits di atas mengandung makna sangat luas, antara lain memberikan hak-hak binatang sesuai habitatnya, seperti kandang dan makanan, bahkan kebebasan sebagaimana disinggung oleh Izzuddin bin Abdus Salam (577-660 H), seorang faqih di dalam karyanya, Qawa'idul Ahkam fi Mashalih al-Anam.

Ma'asyiral Muslimin, Rahimakumullah.

Kita memperhatikan banyak orang memelihara binatang dengan tidak mempedulikan naluri alamiahnya, sehingga dapat membuat 
binatang dan hewan peliharaan tersebut sengsara dan mati. Kegemaran memelihara binatang liar, harus disertai tanggungjawab sebagaimana telah utarakan di atas.

Islam mengajarkan ihsan terhadap hewan. Konsep ihsan mengajak manusia untuk menyayangi, memperhatikan, dan melindungi satwa-satwa, baik yang jinak maupun yang buas, demi keseimbangan alam. Syekh Abdullah ibn Hamad al-Abbudi di dalam Jurnal Majallah al-Buhuts al-Islamiyyah, nomor 34, halaman 149-168, tahun $1412 \mathrm{H}$ yang diterbitkan oleh Al-Azhar Kairo, menyatakan bahwa manusia wajib memiliki rasa sayang dan memperlakukan secara baik terhadap hewan.

Ide ini bukanlah baru dalam khazanah hukum Islam karena sejak masa klasik peradaban Islam telah dikenal fikih hewan dan karyakarya di bidang zoologi. Di antara ensiklopedi termasyhur tentang zoologi adalah karya al-Damiri, Hayah al-Hayawan al-Kubra.

Demikian khutbah kali ini, semoga bermanfaat dan bisa menjadi pedoman bagi kita semua.

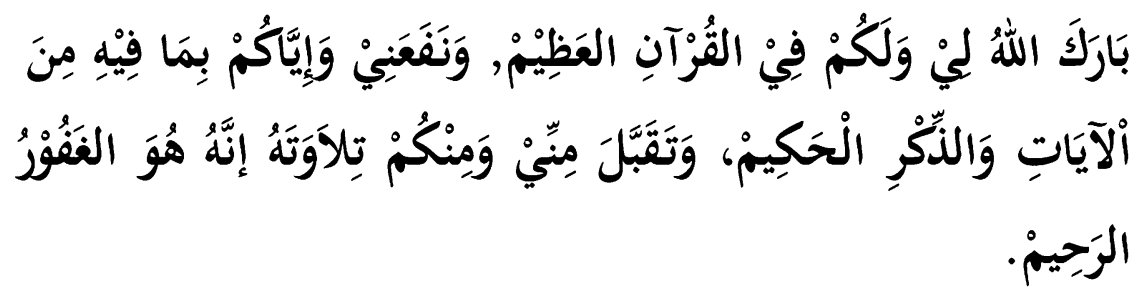




\section{Khuthbah 2}

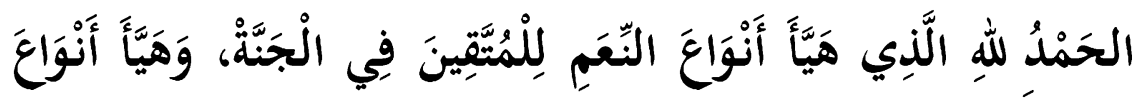

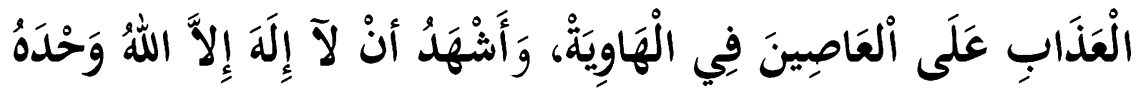

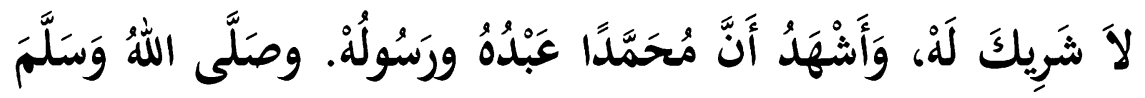

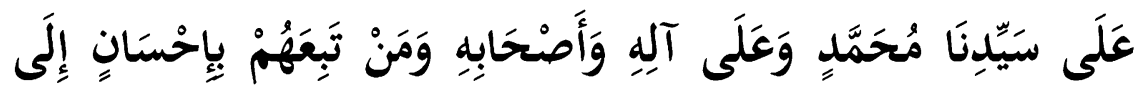

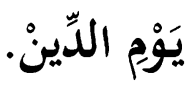

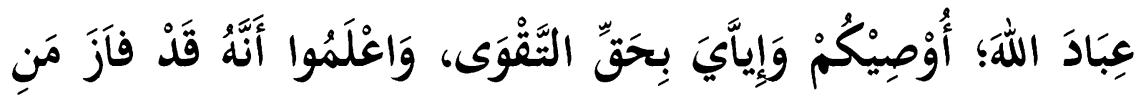
اتَّقَى وَخَابَ مَنْ طَفَى.

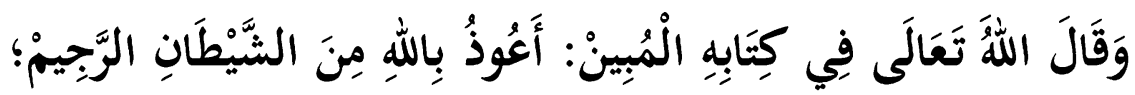

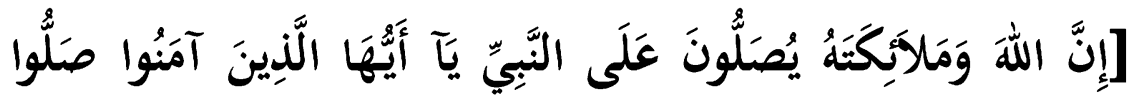
عَلَئْهِ وَسَلِّمُوا تَسْلِيمًا].

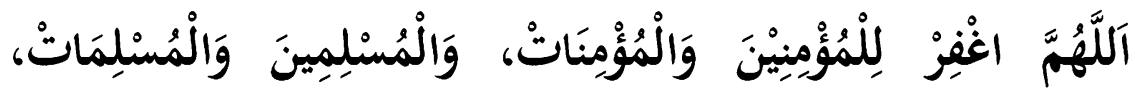

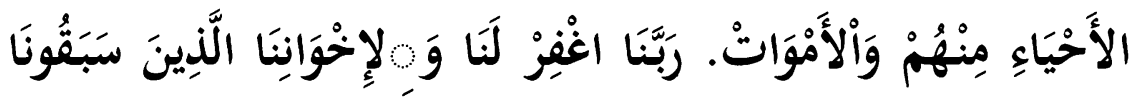

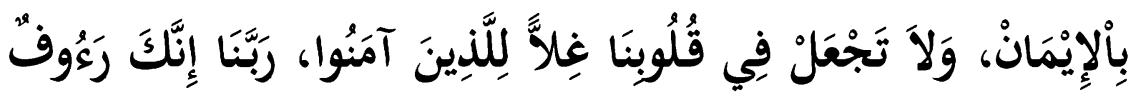

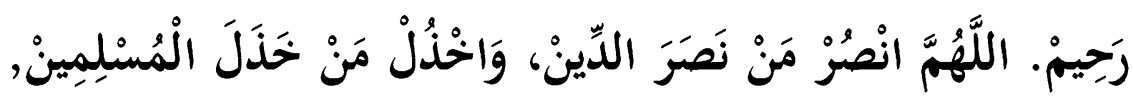

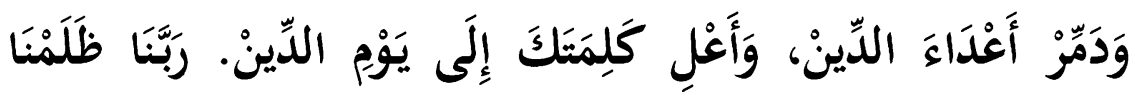




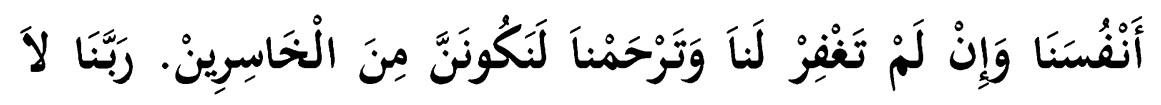

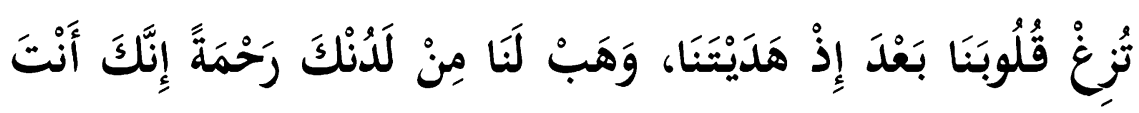

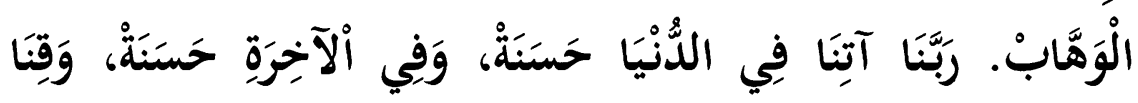

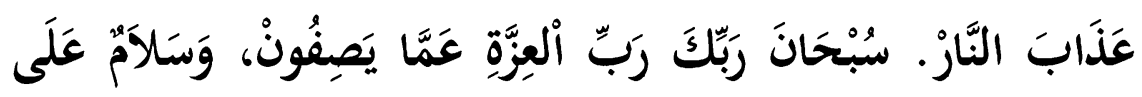

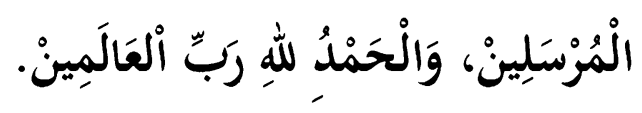

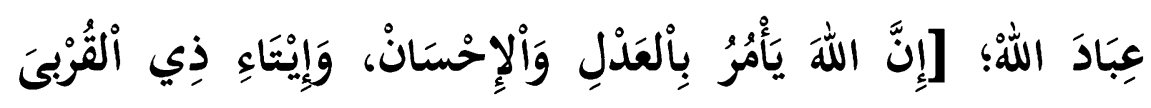

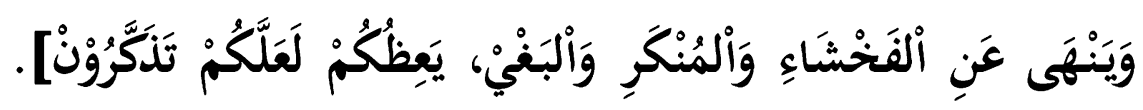
وَاللهُ أَكُبَرْ .- 


\section{తోహై0 \\ PERDAGANGAN SATWA DAN \\ PEMUNAHAN SATWA ADALAH HARAM \\ Khuthbah 1}

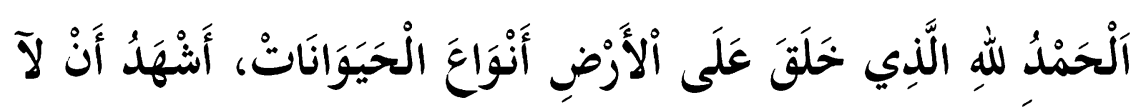

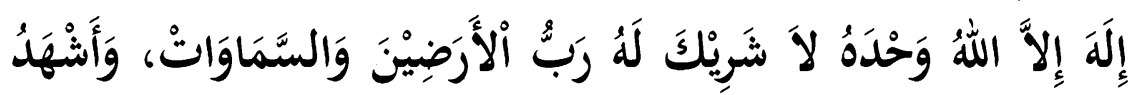

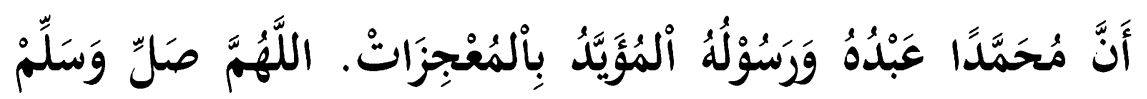

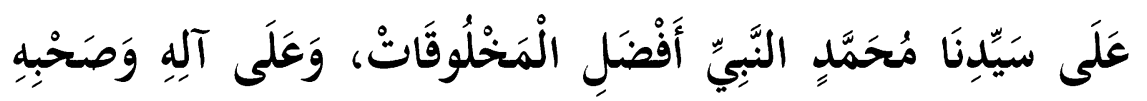

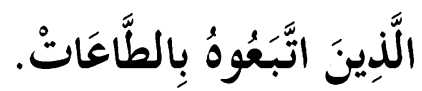

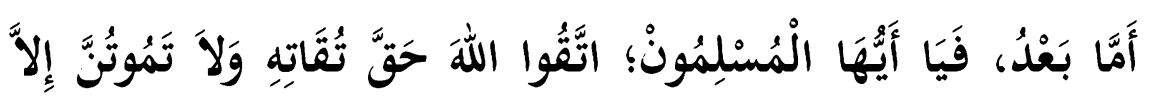

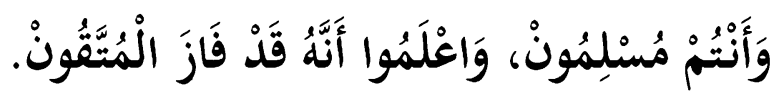

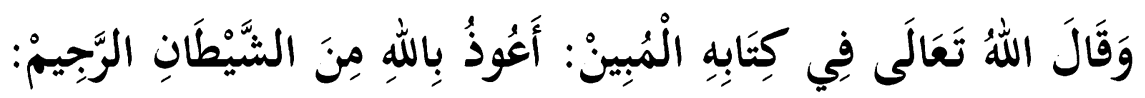

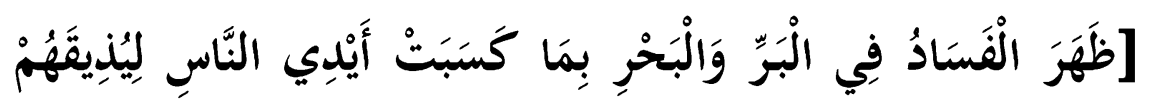

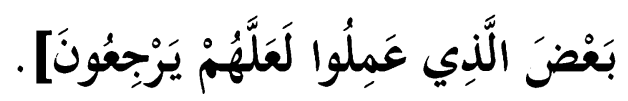

Ma'asyiral Muslimin, Sidang Jum'at Yang Berbahagia.

Kerusakan dalam arti luas di bumi Allah, memang dimulai dari krisis kerusakan akhlak dan moral. Sebab itulah Allah SWT. menurunkan 
Nabi-Nabi pada preode atau fase tertentu untuk memberikan peringatan agar kerusakan tidak terus berlanjut. Sehingga, kerusakan tidak berlanjut membawa bencana kemanusiaan dan alam. Nabi Musa AS. berhadapan dengan Fir'aun, seorang raja yang sangat kejam, congkak dan mengaku Tuhan. Nabi Ibrahim AS. berhadapan dengan Namrud, seorang raja yang sangat bengis dan biadab, dan Nabi Isa AS. berhadapan dengan Herodes (Heraklius), seorang raja yang sangat dhalim.

Kekuasaan manusia terkadang melampaui batas, tidak hanya saling membunuh, tetapi bahkan memusnahkan spesies di muka bumi secara cepat, sehingga spesies itu tidak pernah muncul kembali. Abad ke-21 ini disebut pula fase kepunahan ke enam (the sixt extinction), karena dalam masa sejarah bumi, terjadi beberapa kali kepunahan dan kerusakan dalam waktu ratusan sampai ribuan tahun. Tetapi manusia moderen mampu merusak dan memusnahkan spesies yang ada di bumi hanya dalam waktu ratusan tahun.

Keberadaan makhluk hidup mempunyai arti besar bagi manusia, karena mereka dapat memberikan keuntungan dalam upaya merawat dan melestarikan bumi. Berbagai jenis binatang seperti burung dan banyak satwa lainnya lebih aman berada di alam liar agar berlangsung proses pelestarian dengan fungsi ekologisnya. Karena itulah, Majelis Ulama Indonesia (MUI) mengeluarkan sebuah fatwa tentang Perlindungan Satwa Langka untuk menjaga keseimbangan ekosistem. Kepunahan satwa dikhawatirkan akan memutus mata rantai interaksi alamiah yang dapat menyebabkan kepunahan satu spesies yang berakibat pada bencana bagi manusia. Islam mengajarkan tentang penghargaan terhadap prilaku kasih sayang terhadap satwa untuk memenuhi hak hidupnya. Bahkan jika seorang muslim yang bertanam, sedangkan ia ikhlas sebagian tanamannya dimakan binatang, maka ia memperoleh pahala sedekah. 


\section{عَنْ جَابٍِ بْنِ عَبْدِ اللهِهِ يَقُوْلُ: سَمِعْتُ رَسُوْلَ اللهِ صَلَّى اللهُ عَلَيِْْ

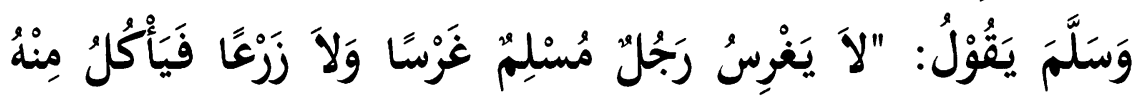

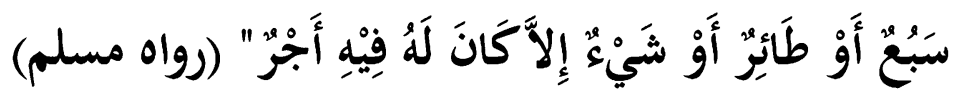

Artinya: "Dari Jabir ibn Abuillah ra, ia berkata: "Rasulullah SAW. bersabda: Tidaklah seorang muslim menanam tanaman kemudian sebgian dari pohon itu dimakan binatang, burung atau yang lainnya, melainkan ia memperoleh pahala" (HR. Muslim)

Menurut Fatwa MUI, hadis ini mendorong kita untuk melakukan aktifitas yang dapat menjamin kelangsungan hidup satwa, meskipun binatang buas sekalipun.

Sabda Nabi SAW.:

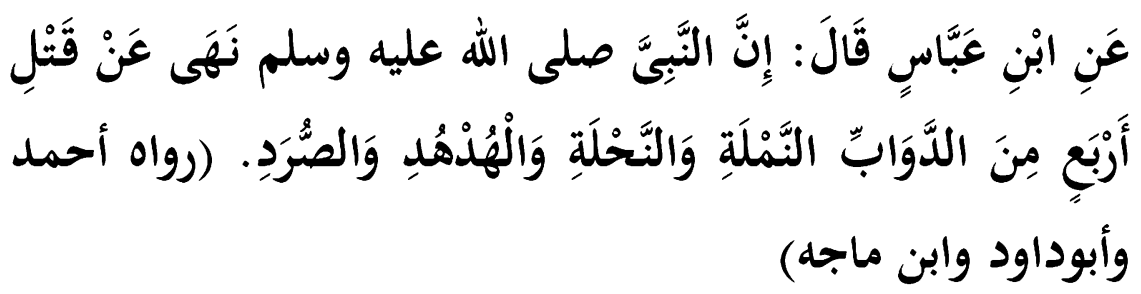

Artinya: "Dari Ibn 'Abbas ra ia berkata: Rasulullah SAW. melarang membunuh empat jenis binatang; semut, lebah, burung hudhud dan shurad". (HR. Ahmad, Abu Dawud, dan Ibn Majah).

Hadis tentang larangan untuk membunuh beberapa jenis hewan tersebut secara mafhum muwafaqah (pengertian yang sebanding) menunjukkan tentang perlunya pelestarian hewan serta larangan melakukan hal yang menyebabkan kepunahannya.

Sabda Nabi SAW.: 


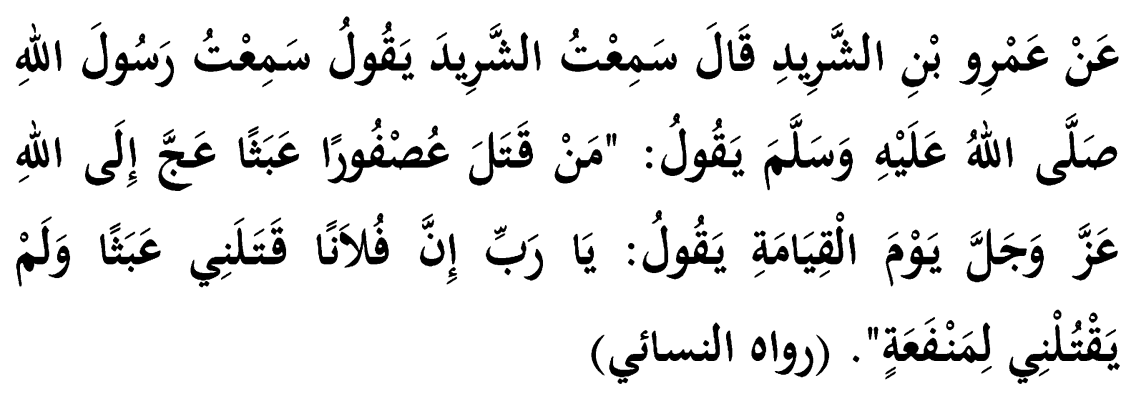

Artinya: "Dari 'Amr ibn Syarid ia berkata: Saya mendengar Syarid ra. berkata: Saya mendengar Rasulullah SAW. bersabda: "Barang siapa membunuh satu ekor burung dengan sia-sia, maka pada hari kiamat burung itu akan melapor kepada Allah SWT, dan berkata: "Wahai Tuhan, sesungguhnya si fulan telah membunuhku sia-sia, dan tidak untuk suatu manfaat". (HR. An-Nasa'i)

Ma’asyiral Muslimin, Sidang Jum’at Yang Berbahagia.

Belakangan ini semakin marak perburuan dan perdagangan satwa. Hal ini merupakan ancaman utama terhadap kelangsungan berbagai jenis satwa, atau spesies yang pada ujungnya dapat menyebabkan kepunahan. Nilai ekonomi yang tinggi dari satwa-satwa tersebut baik secara utuh maupun bagian-bagian tubuhnya telah mendorong manusia untuk terus melakukan perburuan dan perdagangan ilegal. Perburuaan dan perdagangan ilegal satwa sudah merupakan kejahatan terhadap satwa yang dilakukan secara terorganisir dengan rapi dan memiliki jaringan luas, mulai dari tingkat lokal, hingga internasional.

Perdagangan ilegal satwa merupakan bisnis yang memberikan keuntungan besar, dan menempati urutan kelima setelah narkoba, senjata api dan perdagangan manusia, dengan perkiraan uang yang beredar antara 10-12 milyar USD per tahun. Bisnis ini cenderung meningkat seiring peningkatan permintaan terhadap bagian-bagian 
tubuh satwa dilindungi. Berasal dari Indonesia, antara lain; tulang dan kulit harimau, gading gajah, sisik dan daging trenggiling, serta paruh burung enggang gading. Menjual barang-barang tersebut, berarti pula membunuh satwa tersebut tanpa alasan yang benar secara syar'i.

Islam memandang pentingnya eksistensi spesies satwa sebagai makhluk hidup karena mereka sesama ciptaan Allah SWT. yang bertasbih. Seperti diriwayatkan dalam suatu hadist:

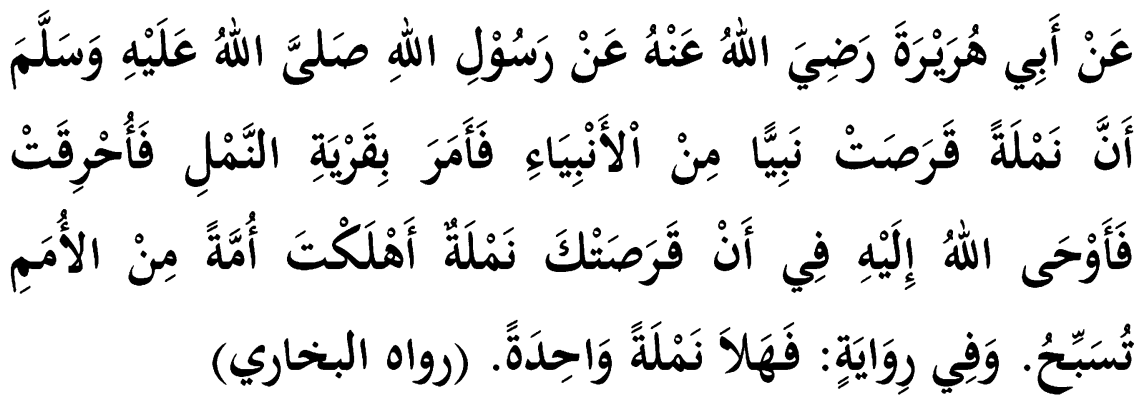

Dari Abi Hurairah ra dari Rasulullah SAW bahwa ada semut yang menggigit seorang nabi diantara nabi-nabi Allah, lantas ia memerintahkan untuk mencari sarang semut dan kemudian sarang semut tersebut dibakar. Maka Allah SWT memberikan wahyu kepadanya tentang (bagaimana) engkau digigit satu semut dan engkau memusnahkan seluruh semut yang (sama-sama) bertasbih. Dan dalam satu riwayat (terdapat kalimat yang artinya): "mengapa tidak hanya satu semut (yang menggingit)? (HR. Bukhari).

Komunitas semut tetap dihargai dengan tidak menghukum dan memusnahkannya, kecuali yang mengganggu saja. Dengan demikian, menyelematkan makhluk Allah SWT merupakan bagian penting dari ajaran Islam.

Bagaimanakah hukumnya, membunuh satwa yang hanya sedikit jumlahnya dan dikategorikan langka, kemudian memperdagang- 
kannya? Imam Ahmad al-Khatthabi dalam Ma'alim al-Sunan (4/289) menjelaskan larangan pemunahan hewan secara keseluruhan:

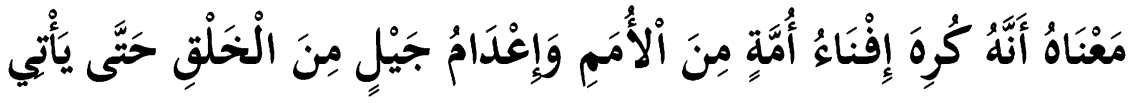

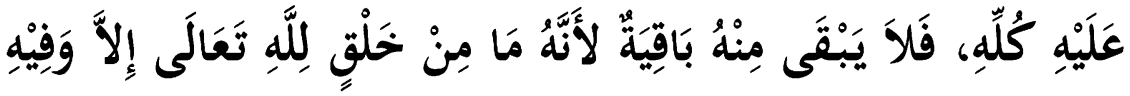

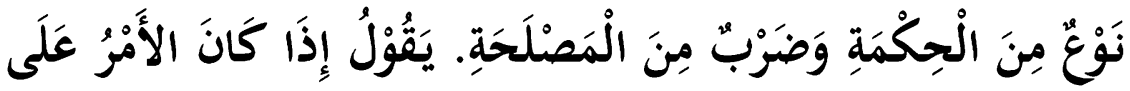

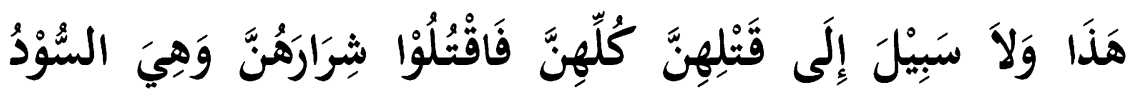

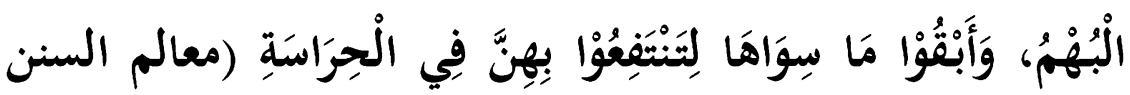 289/4، لأحمد بن حمد بن محمد الخطابي)}

Artinya: "Pengertiannya, sangat dibenci pemunahan umat dan peniadaan generasi makhluk hidup sampai tidak tersisa sedikitpun. Tidak ada satupun dari ciptaan Allah SWT kecuali terdapat hikmah dan mashlahah. Jika demikian, maka tidak ada jalan (yang dijadikan alasan untuk membenarkan) pada pembunuhan hewan secara keseluruhan (pemunahan). Maka bunuhlah hewan yang membahayakan dan biarkan selainnya agar dapat dimanfaatkan untuk pengedalian".

Berdasarkan dalil diatas, MUI menyimpulkan, bahwa membunuh, menyakiti, menganiaya, memburu, atau melakukan tindakan yang mengancam kepunahan satwa langka hukumnya haram kecuali ada alasan syar'i, seperti melindungi dan menyelamatkan jiwa manusia. Dan juga melakukan perburuan dan perdagangan ilegal satwa langka hukumnya haram.

Demikian khutbah kali ini, semoga ini bermanfaat dan bisa menjadi pedoman bagi kita semua. 


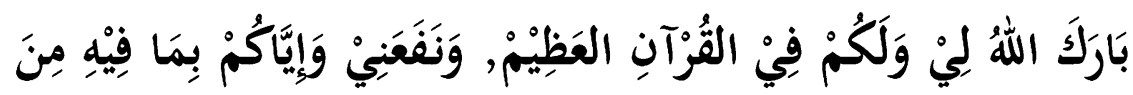

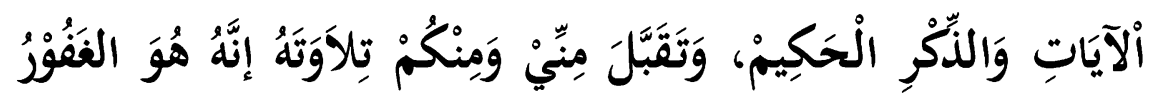
الزَحِيمْ. 


\section{Khuthbah 2}

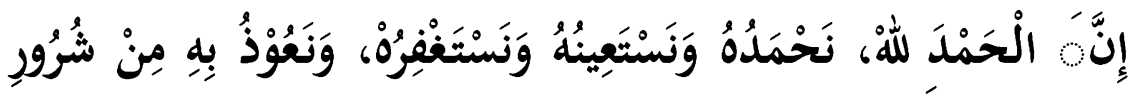

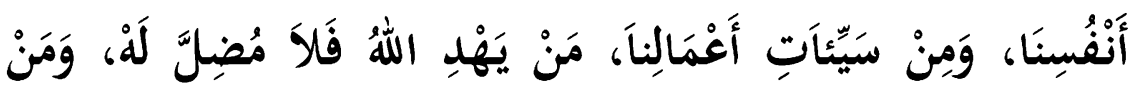

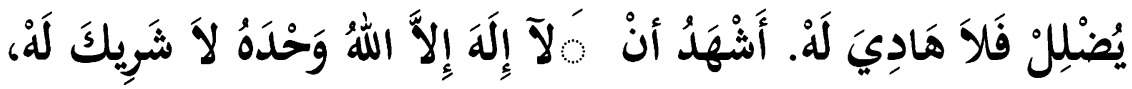

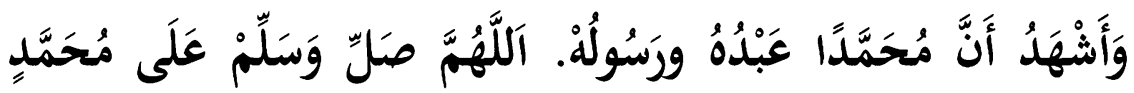

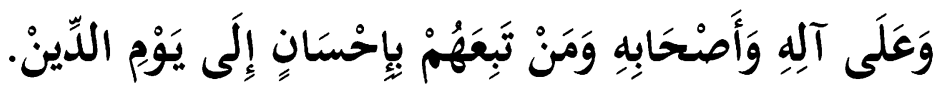

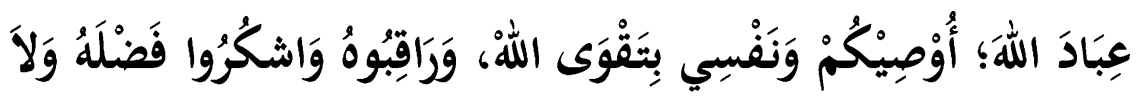
تَجْحَدُوهْ.

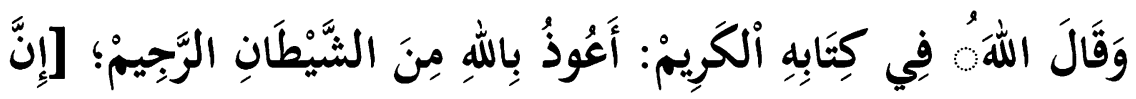

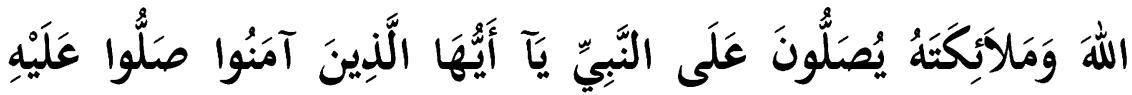

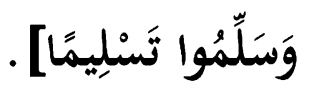

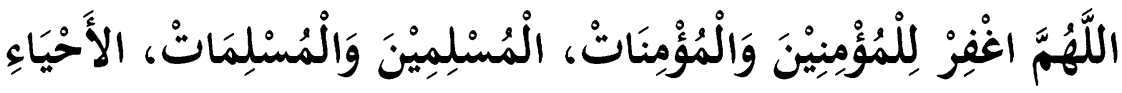

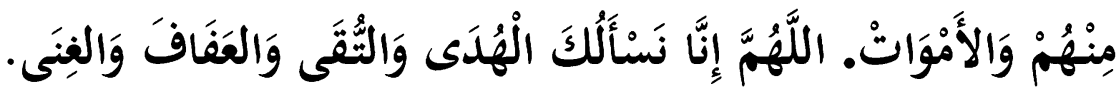

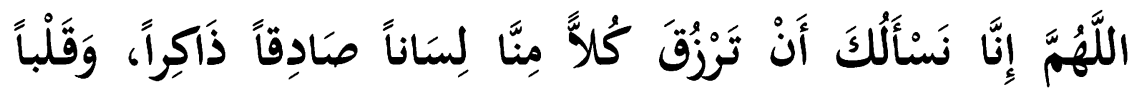

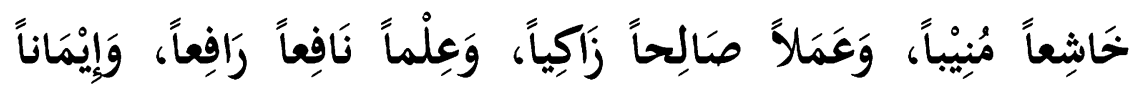

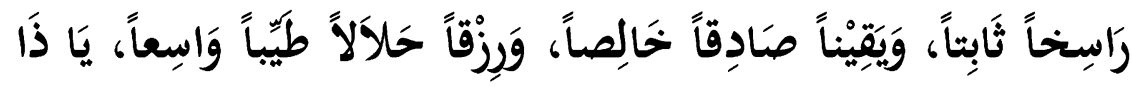




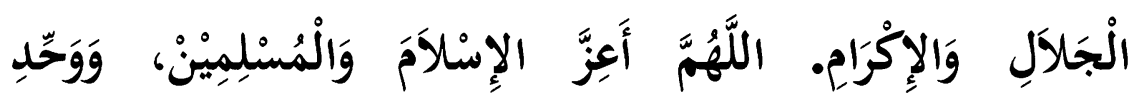

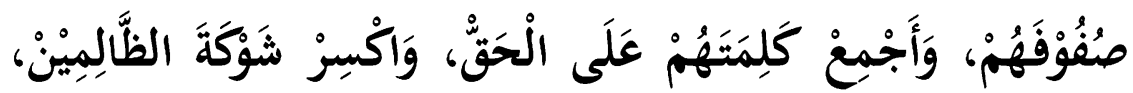

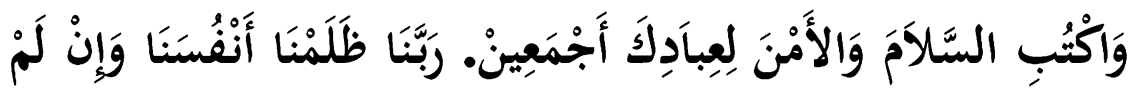

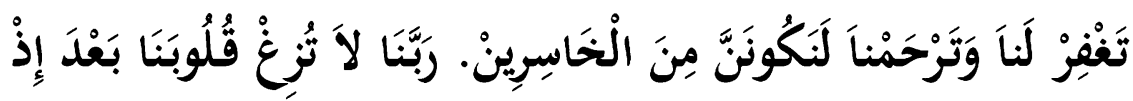

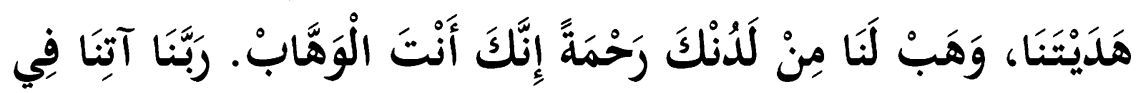

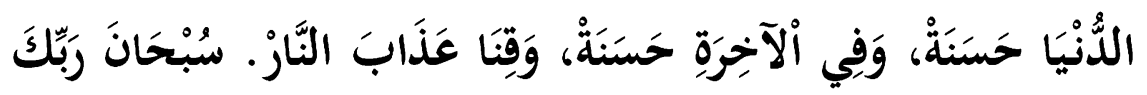

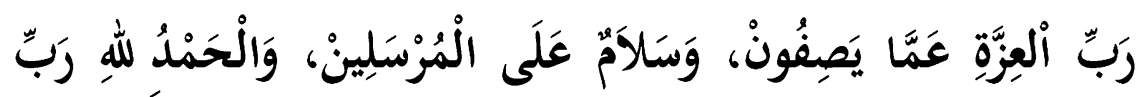
ألعَالَمِيْ.

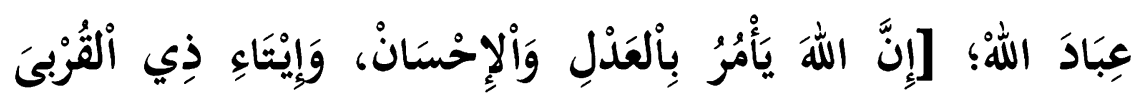

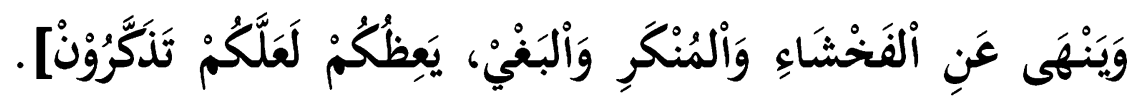

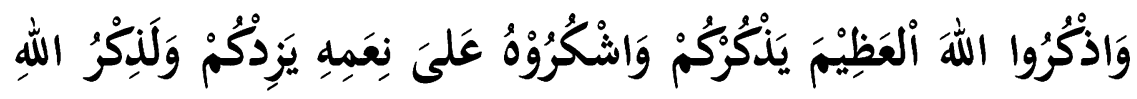

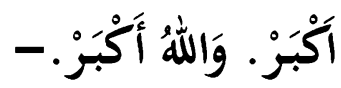




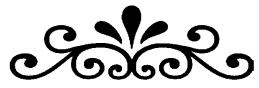 \\ MANFAAT MELESTARIKAN SATWA LANGKA}

\section{Khuthbah 1}

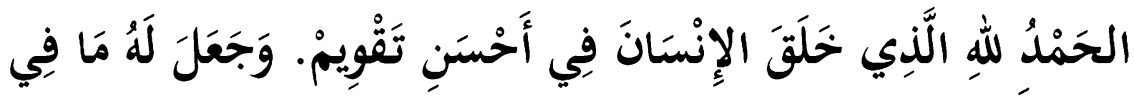

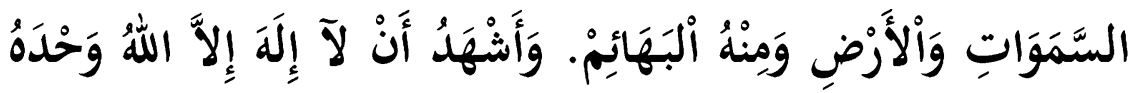

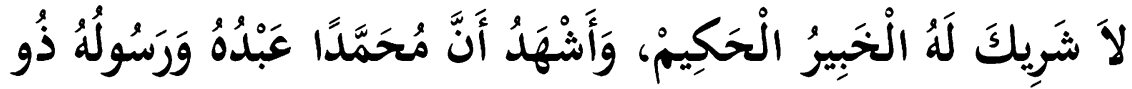

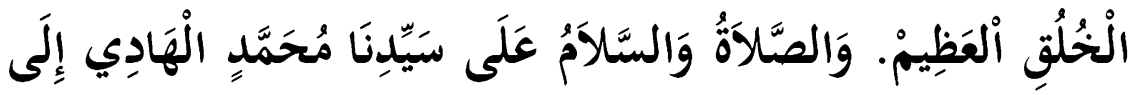

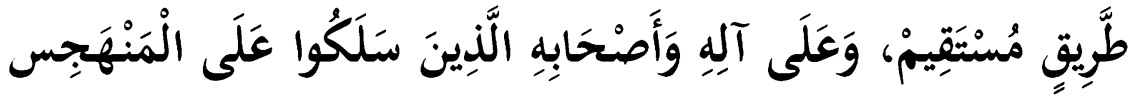
القَويمْ .

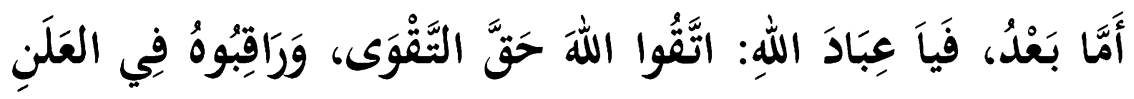

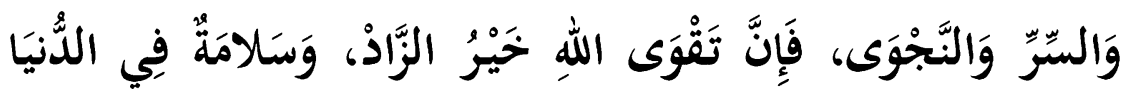

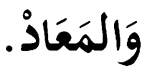

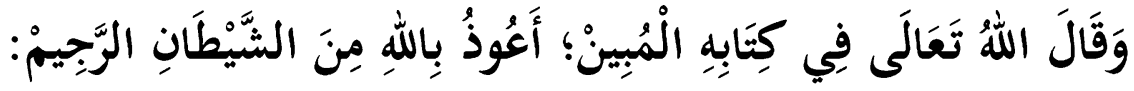

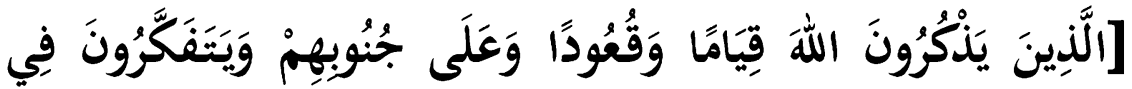

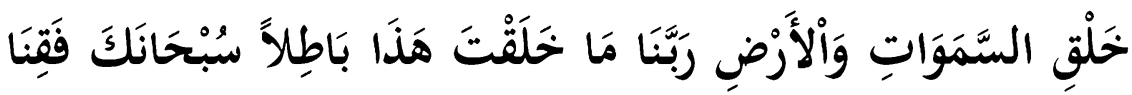

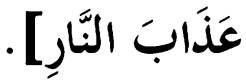


Jama'ah Jum'at Yang Dimuliakan Allah.

Di dalam Al-Qur'an, surat Al-Baqarah, ayat 31-33 terdapat kisah mengenai permohonan para Malaikat kepada Allah SWT. agar menggagalkan rencana-Nya untuk menciptakan manusia di muka bumi ini karena mereka beranggapan, bahwa manusia akan melakukan kerusakan dan pertumpahan darah. Permohonan para Malaikat itu diajukan setelah Allah SWT. menyampaikan kepada mereka akan rencana-Nya itu. Namun, rencana Allah SWT. tidak dapat ditolak. Setelah Nabi Adam AS, manusia pertama itu tercipta, Allah SWT. mengajarkan kepadanya mengenai berbagai hal. Kemudian semua itu diperlihatkan kepada para Malaikat, lalu mereka diperintahkan untuk menjelaskannya. Para Malikat tidak mampu menjelaskannya, dan mengaku hanya mengetahui sebatas apa yang telah diajarkan kepadanya. Lalu Allah SWT. menyuruh Adam AS. untuk menjelaskannya kepada mereka. Selanjutnya Allah SWT. menegaskan, bahwa itulah rahasia mengenai rencana-Nya untuk menciptakan manusia sebagai khalifah di muka bumi.

Keberadaan manusia di muka bumi sangat penting untuk menguasai berbagai ilmu pengetahuan agar mampu menciptakan kehidupan dunia yang aman dan sejahtera di bawah naungan ridlo Sang Pencipta, Allah SWT. Dengan demikian, manusia dituntut untuk mengenali, mengolah dan memanfaatkan segala sesuatu yang ada di bumi, bahkan di angkasa. Sehingga, atas idzin Allah SWT. dan kuasa-Nya, lambat laun manusia mampu merumuskan berbagai bidang ilmu pengetahuan untuk mampu mengolah dan memanfaatkan dunia bagi kehidupan manusia, termasuk menjaga, merawat dan melestarikan keutuhannya. Inilah diantara tujuan, fungsi dan tugas diciptakan manusia.

Jama'ah Jum'at Yang Berbahagia.

Majelis Ulama Indonesia (MUI) mengeluarkan Fatwa nomor 04 tahun 2014 tentang "Pelestarian Satwa Langka Untuk Menjaga Ke- 
seimbangan Ekosistem". Isi fatwa tersebut adalah kita sebagai umat Islam dihimbau untuk ikut berperan aktif dalam upaya menjaga, merawat, serta melestarikan hewan, terutama berbagai jenis hewan yang terancam punah. Firman Allah SWT. dalam surat Yasin ayat 71-72:

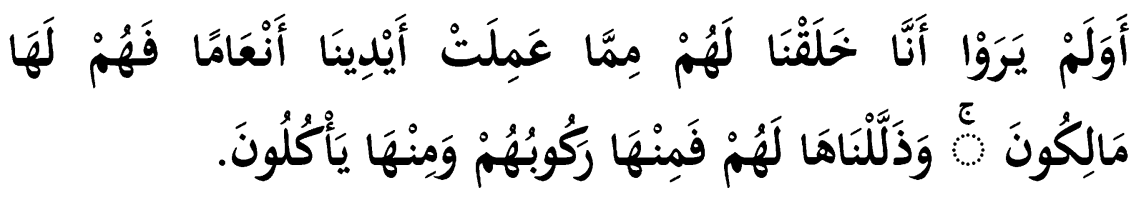

Artinya: "Dan Apakah mereka tidak melihat bahwa sesungguhnya Kami telah menciptakan binatang ternak untuk mereka yaitu sebahagian dari apa yang telah Kami ciptakan dengan kekuasaan Kami, lalu mereka menguasainya? Dan Kami tundukkan binatang-binatang itu untuk mereka; Maka sebahagiannya menjadi tunggangan mereka dan sebahagiannya mereka makan". (QS. Yasin [36] : 71-72)

Tentang keberadaan satwa dan binatang yang ada di bumi ini, dalam dekade terakhir memang memprihatinkan. Laporan ilmiah dari studi tentang keberadaan spesies makhluk hidup yang ada di bumi, mencatat bahwa terdapat laju kepunahan hingga mencapai $58 \%$ antara tahun 1970 hingga 2012, dan bahkan tingkat kepunahan akan mencapai $67 \%$ pada tahun 2020 .

Keberadaan satwa atau binatang baik di alam liar, dengan sifat kerimbaannya maupun yang hadir di tengah manusia. Ternyata mempunyai peran penting untuk tetap dipertahankan. Perbaikan kualitas ternak dan tumbuhan yang telah ada secara domestik (dipelihara ditengah manusia), sangat bergantung dengan stok aslinya di alam (di hutan-hutan).

Jadi, pesan-pesan kuat dari agama sebagaimana dikemukakan dalam fatwa MUI tersebut, sangatlah bermakna agar secara praktis, 
umat Islam tidak hanya memahami pedoman dan nasehat agama yang membawa kemaslahatan, tetapi juga pada perbaikan isi dunia. Firman Allah SWT. dalam surat al 'Araf, 57:

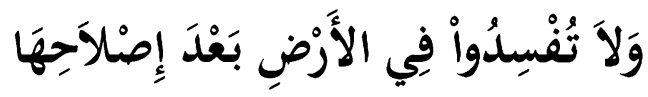

Artinya: "Dan janganlah kamu melakukan kerusakan di bumi setelah menjadi baik".

Majelis Ulama Indonesia (MUI) menegaskan pentingnya melestarikan satwa dan tumbuhan untuk mempertahankan keseimbangan ekosistem kehidupan. Banyak terjadi bencana, seperti banjir, tanah longsor dan lainnnya merupakan dampak dari tidak adanya keseimbangan ekosistem. Keberadaan satwa menjadi penting karena satwa mempunyai tugas langsung secara biologis, selain memerlukan pula kawasan dengan ekosistem yang seimbang. Sebagai contoh, burung penyebar biji-bijian, seperti burung enggang dan kelelawar sepanjang hidupnya dapat menyebarkan ratusan ribu biji-bijian sepanjang radius terbangnya. Inilah tugas rutin mereka yang tidak bisa dilakukan oleh manusia. Penyebaran biji dan penyerbukan alamiah dilakukan oleh binatang dan sebagian oleh angin sebagaimana firman Allah SWT. dalam surat Ali Imran 191:

\section{رَبَنَّا مَا خَلَقْتَ هَذَا بَاطِالًَ.}

"Ya Tuhan kami, tidaklah Engkau menciptakan ini dengan sia-sia" (QS. Ali Imran [3]: 191)

Ayat di atas menegaskan kepada kita, bahwa tidak ada di antara ciptaan Allah SWT. yang sia-sia. Semuanya mempunyai fungsi dan manfaat yang berbeda dan saling melengkapi. 
Tidak banyak bangsa yang dikaruniai oleh kekayaan satwa seperti Indonesia. Keberadaan mereka dapat juga merupakan sumber rezeki apabila dikelola dengan baik. Sumber-sumber kehidupan dapat dicari dan dilakukan dengan cara berkelanjutan, dengan cara yang inovativ yang sekiranya tidak merusak habitat mereka, tetapi hendaknya dengan mempertahankan keberadaanya, sehingga keuntungan jangka panjang dapat diperoleh dari kehadiran makhluk Allah SWT. tersebut.

Sebaliknya, apabila terjadi kepunahan, maka manusia Indonesia yang menjadi saksi atas kepunahan tersebut dan akan disesalkan oleh generasi penerus kecuali. Kita mulai dari sekarang untuk mereformasi prilaku kita mengakhiri kebiasaan berburu hewan liar, membatasi konsumsi, dan membangun komitmen yang selaras dengan kandungan Fatwa MUI tentang Satwa Langka.

Demikian khutbah kali ini, semoga bermanfaat dan bisa menjadi bahan renungan bagi kita semua.

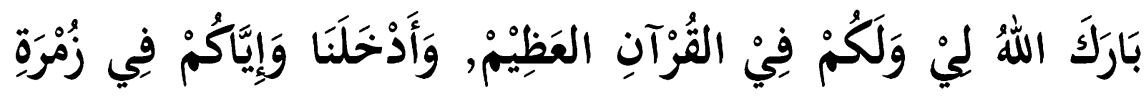

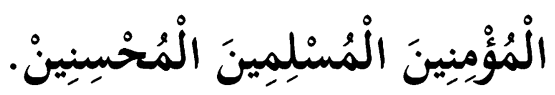




\section{Khuthbah 2}

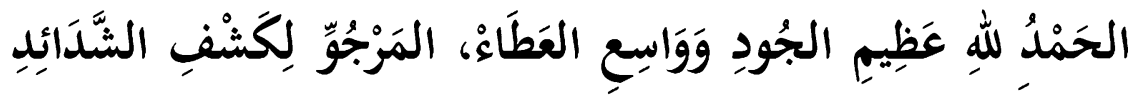

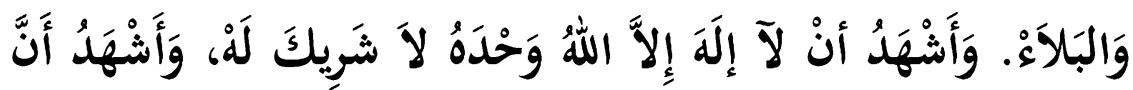

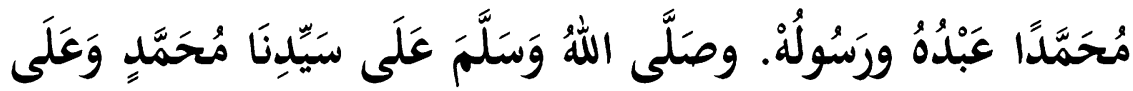

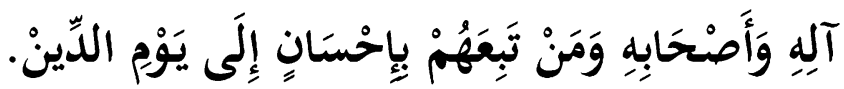

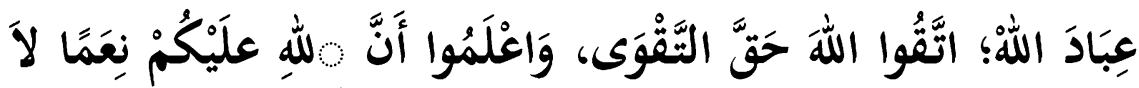

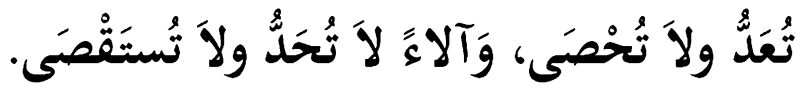

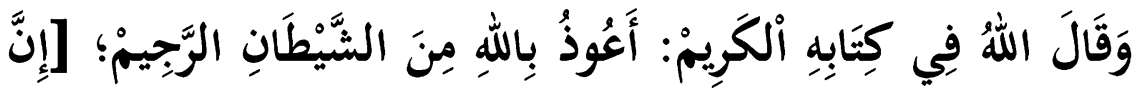

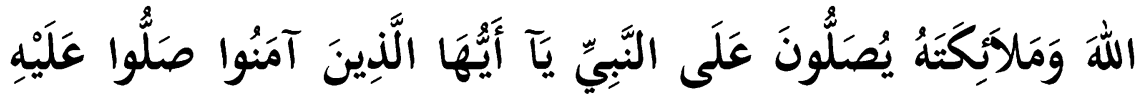
وَسَلُِّوا تَسْلِيمًا]

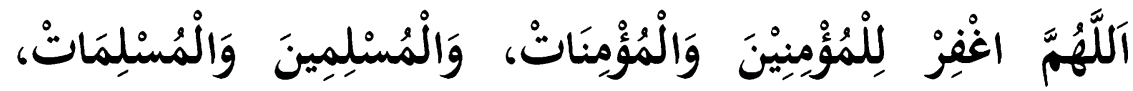

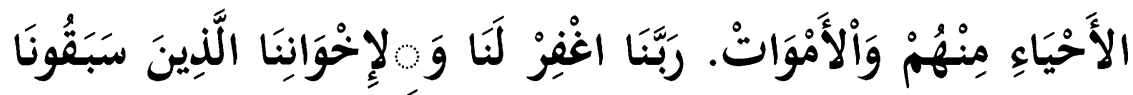

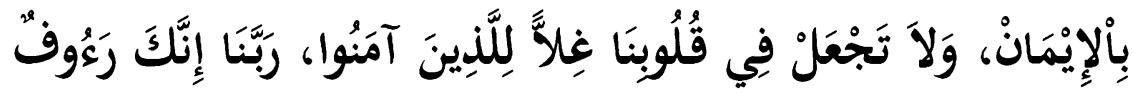

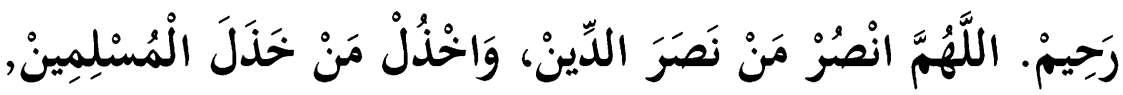

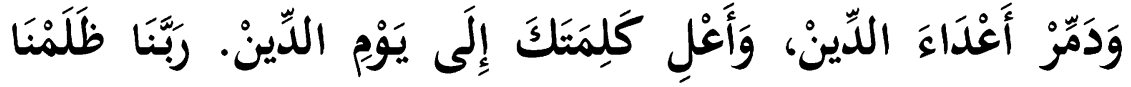

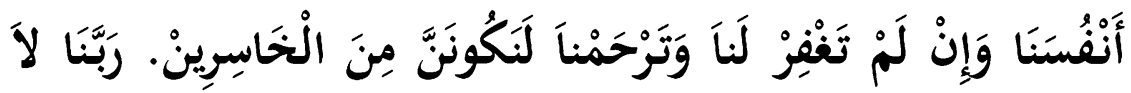




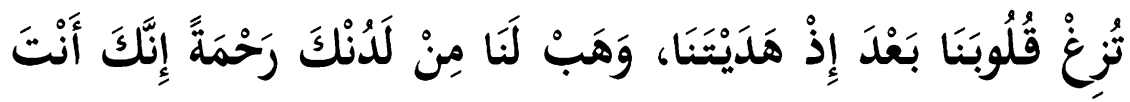

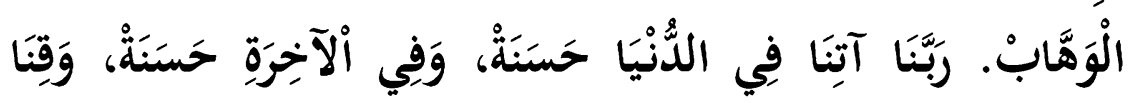

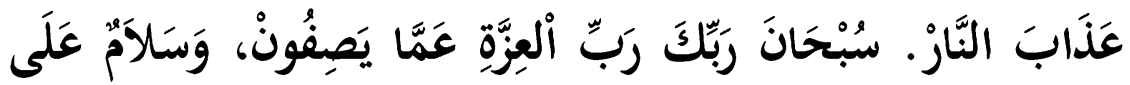

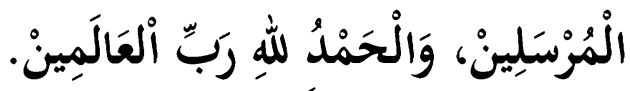

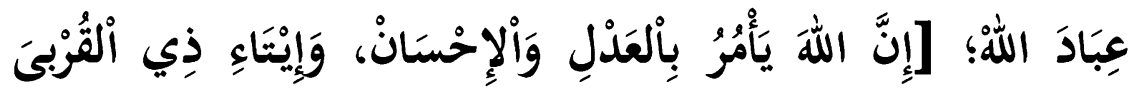

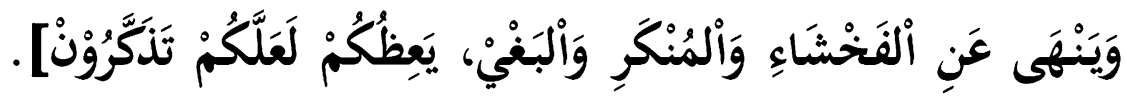

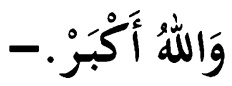




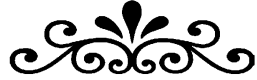 \\ MELINDUNGI DAN MELESTARIKAN ALAM TERMASUK SATWA \\ Khuthbah 1}

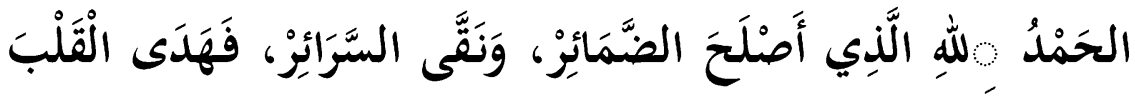

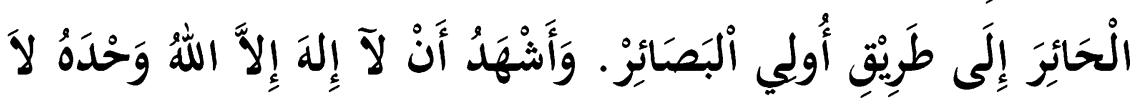

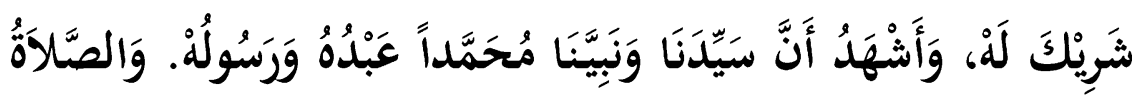

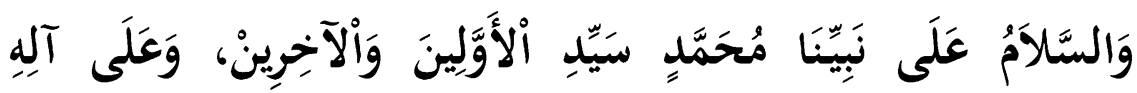

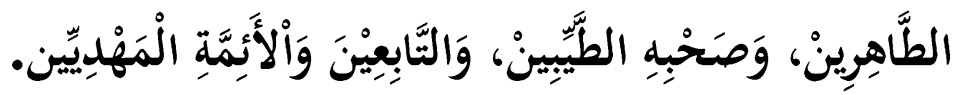

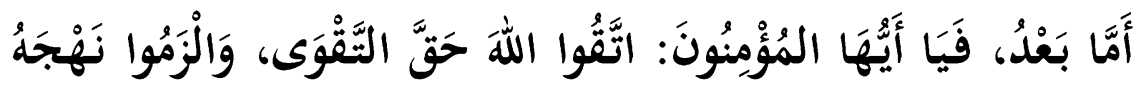

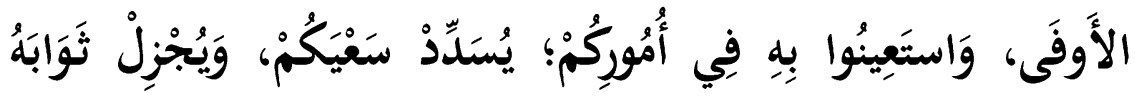

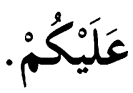

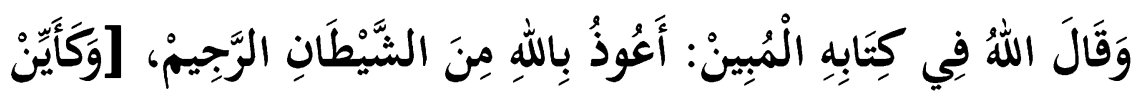

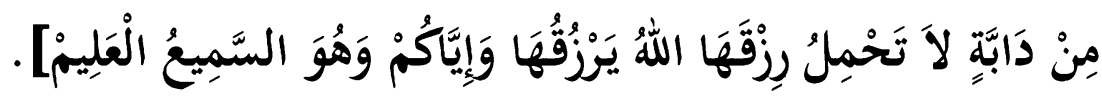

Ma'asyiral Muslimin, Jama'ah Jum’at Yang Berbahagia.

Bumi ini diciptakan oleh Allah SWT. dengan berbagai macam kelengkapan yang sinergis antara satu dan lainnya. Diturunkan hujan menjadi faktor tumbuhnya bermacam jenis pepohonan yang tidak 
terhitung jumlahnya. Semua itu adalah karunia Allah SWT. untuk kemakmuran dan kesejahteraan hidup manusia.

Firman Allah SWT:
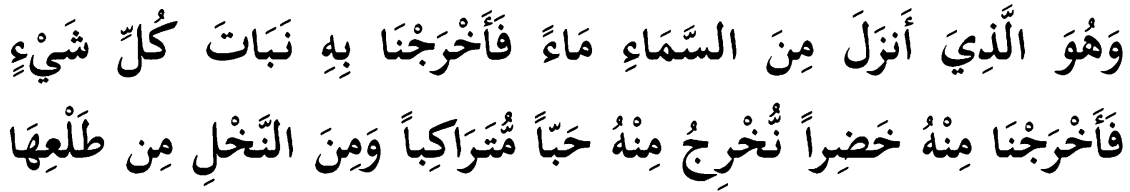

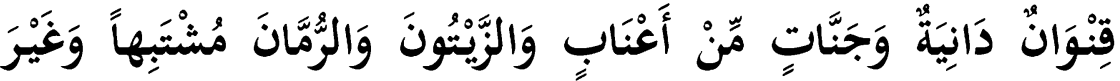

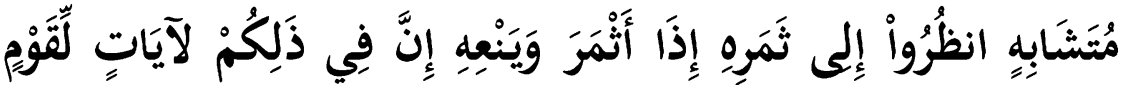
يُوَِْْنْوَنَ.

Artinya: "Dan Dialah yang menurunkan air hujan dari langit, lalu kami tumbuhkan dengan air itu segala macam tumbuh-tumbuhan, maka Kami keluarkan dari tumbuh-tumbuhan itu tanaman yang menghijau, Kami keluarkan dari tanaman yang menghijau itu butir yang banyak; dan dari mayang kurma mengurai tangkai-tangkai yang menjulai, dan kebun-kebun anggur, dan (Kami keluarkan pula) zaitun dan delima yang serupa dan yang tidak serupa. Perhatikanlah buahnya di waktu pohonnya berbuah, dan (perhatikan pulalah) kematangannya. Sesungguhnya pada yang demikian itu ada tanda-tanda (kekuasaan Allah) bagi orang-orang yang beriman. (QS. Al-An'am [6]:99)

Ayat di atas menjelaskan, betapa pentingnya air dalam faktor tumbuhnya berbagai macam pepohonan dan kesuburannya, lalu berbuah untuk kemakmuran manusia. Pada sisi lain tidak boleh diabaikan, terdapat beberapa hal yang lepas dari perhatian banyak orang. Ada banyak tumbuhan dengan bunga yang dilengkapi dengan serangga penyerbuk. Ada banyak burung yang memakan buah-buahan dan menyebarkan bijinya ke segala penjuru sesuai 
jangkauan terbangnya. Inilah bukti nyata, bahwa hujan, tumbuhan, dan satwa tidak dapat dipisahkan keberadaannya dari kehidupan manusia. Oleh karena itu, manusia merupakan bagian ciptaan Allah SWT. yang diberi pengetahuan, kekuasaan dan kewenangan mengelola dan memanfaatkan bumi seisinya harus mampu menjaga, melindungi, merawat, dan melestarikan seluruh ciptaan-Nya untuk kemakmuran hidup mereka.

Khususnya satwa sebagai bagian dari makhluk ciptaan Allah SWT. ternyata berperan dalam mendampingi keberadaan manusia. Oleh karena itu, satwa dengan berbagai macam jenis dan spesiesnya harus diperlakukan dengan baik dan dijaga kelestariannya. Allah SWT. menegaskan, bahwa burung sebagai bagian dari satwa adalah ummat, seperti halnya manusia sebagaimana di dalam firman-Nya:

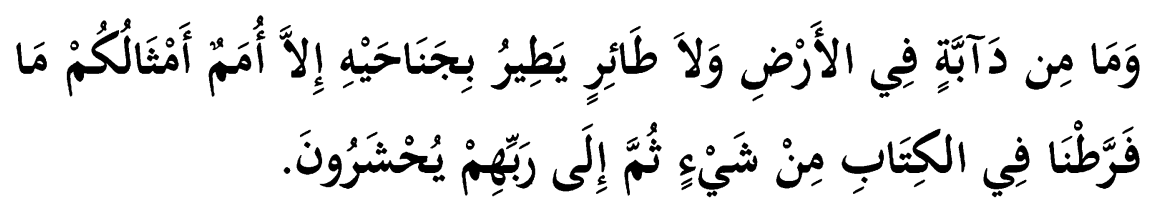

Artinya: "Dan tiadalah binatang-binatang yang ada di bumi dan burung-burung yang terbang dengan kedua sayapnya, melainkan umat-umat (juga) seperti kamu. Tiadalah Kami alpakan sesuatupun di dalam Al Kitab, kemudian kepada Tuhanlah mereka dihimpunkan. (Qs. Al-An'Am [6]: 38)

Dalam beberapa riwayat hadits, Nabi SAW. memerintahkan untuk berlaku baik terhadap binatang. Suatu ketika Nabi SAW. bepergian bersama beberapa orang sahabat beliau. Dalam perjalanan itu salah seorang sahabat melihat seekor burung dengan dua anaknya. Sahabat itu kemudian mengambil dua anak burung dan membawanya menyertai perjalanan. Induk burung yang dua anaknya dibawa itu lalu membuntuti rombongan Nabi SAW. bersama beberapa orang shahabat. Tidak lama kemudian, hal itu diketahui oleh beliau, lalu 
bersabda: "Siapakah yang menyusahkan burung ini karena mengambil anaknya? Kembalikan anaknya padanya". (HR. Abu Daud). Demikian pula beliau pernah melarang orang membebani hewan dengan muatan yang berat. Beliau pernah memerintahkan kepada orang yang menjadikan hewan sebagai kendaraan untuk memperlakukan hewan itu secara baik, dan memperhatikan kesehatannya. Beliau juga pernah memerintahkan kepada orang yang memelihara hewan untuk merawat dengan baik hewan peliharaannya.

Dalam hal menyembelih hewan, Nabi SAW. pernah pula berpesan, bahwa ketika hewan itu akan disembelih, hewan itu harus ditenangkan dan tidak dalam ketakutan, pisau untuk menyembelih harus tajam agar hewan yang disembelih tidak tersiksa kesakitan. Beliau juga berpesan agar tidak membunuh hewan kecuali menyembelihnya untuk keperluan dimakan. Kalaulah hewan perlu dibunuh karena sesuatu hal, haruslah tidak dengan cara menganiaya, seperti mengikat atau mengurungnya lalu melemparinya sampai mati. Dalam hal berburu hewan, beliau melarang perburuan binatang dengan cara tidak wajar, misalnya dengan melempar batu, menjebak jeratan dan sebagainya yang dapat mencederai dan menyengsarakannya. Dalam hal menjadikan hewan untuk permainan, pada suatu hari Nabi SAW. melewati sekelompok orang yang sedang melempar-lempar seekor burung untuk permainan, lalu beliau melarangnya dan bersabda: "Allah SWT. mengutuk orang yang melakukan ini". Dalam suatu riwayat, Nabi SAW. pernah bersabda:
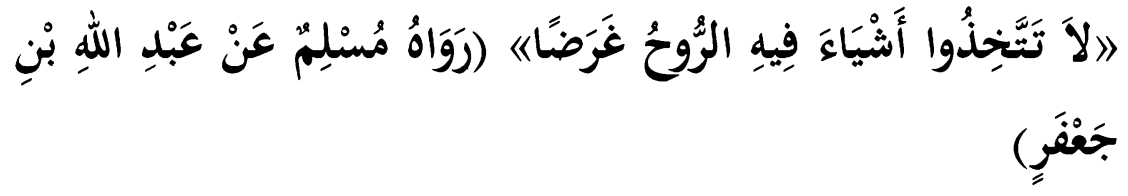

Artinya: "Jangan kamu menjadikan sesuatu yang mempunyai roh itu sebagai obyek (sasaran)." (HR. Muslim dari Abullah ibn Ja'far). 
Jama'ah Jum'at Yang Berbahagia.

Beberapa hadits sebagaimana di atas merupakan perhatian dan kepedulian Nabi SAW. dalam menuntun ummatnya untuk memiliki akhlak yang baik terhadap satwa atau hewan sesama makhluk ciptaan Allah SWT. Akhlak yang baik tersebut akan dapat mengendalikan penganiayaan, penyiksaan dan kematian satwa secara sia-sia. Sehingga populasinya tidak terganggu, kelestariannya tetap terjaga, dan keberadaanya dalam menyertai kehidupan manusia dapat membawa kemakmuran di muka bumi ini.

Demikian khutbah kali ini, semoga bermanfaat dan bisa menjadi bahan renungan bagi kita semua.

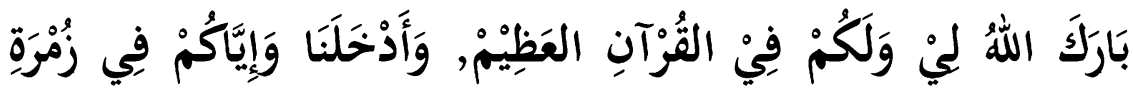

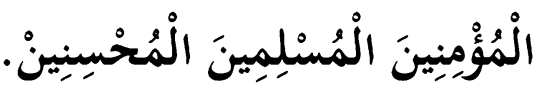




\section{Khuthbah 2}

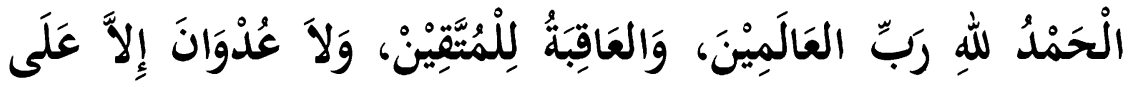

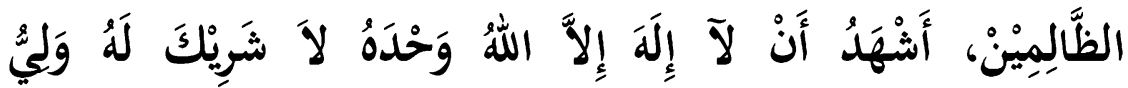

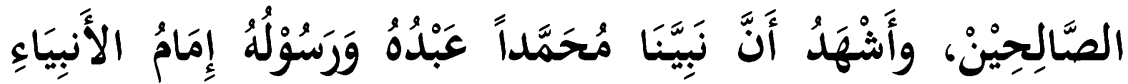

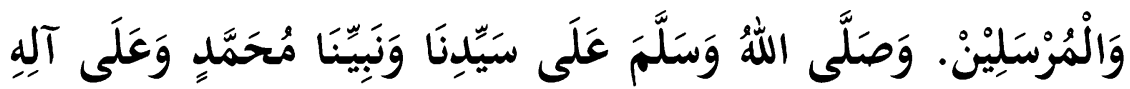

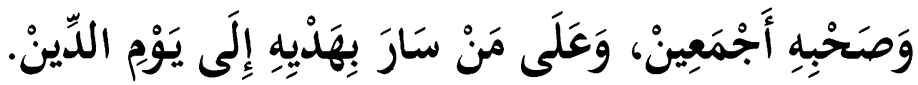

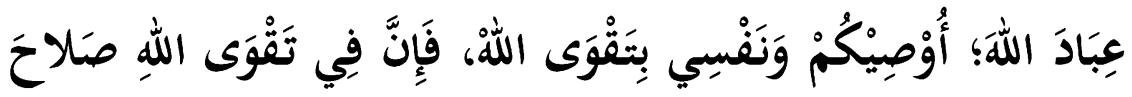

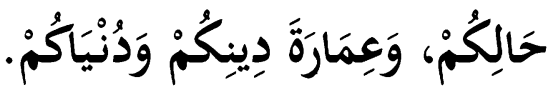

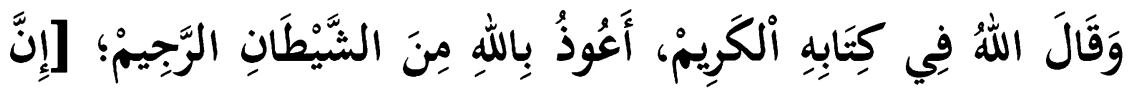

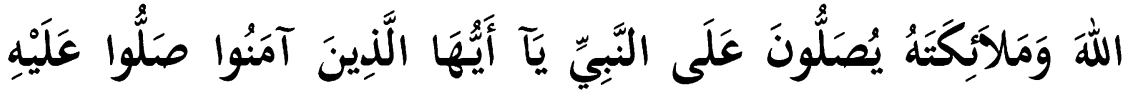

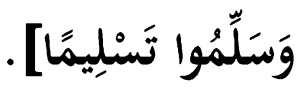

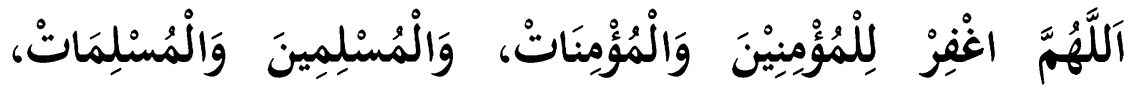

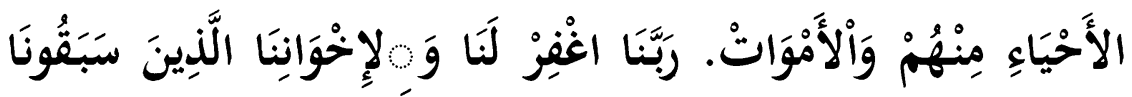

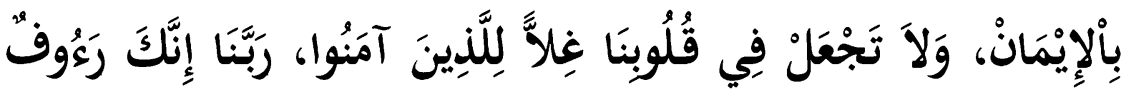

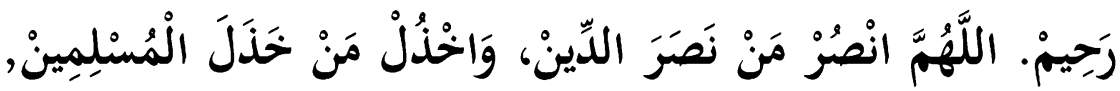




\section{తోహై \\ MELINDUNGI SATWA DARI \\ KEPUNAHAN}

\section{Khuthbah 1}

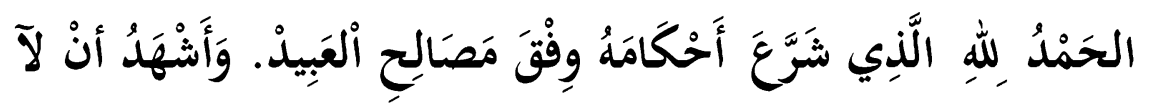

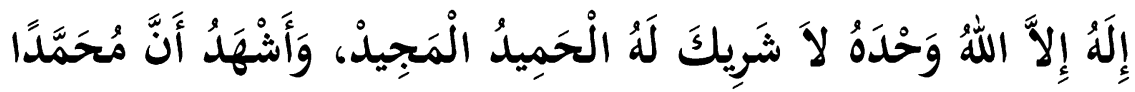

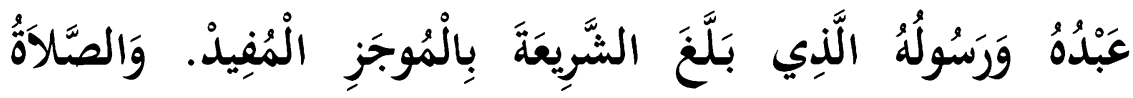

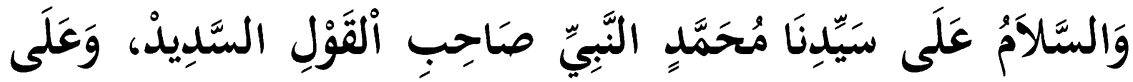

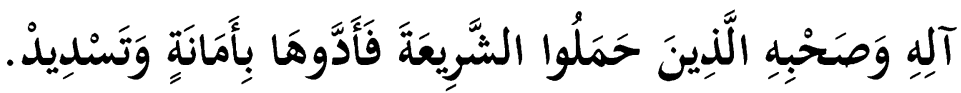

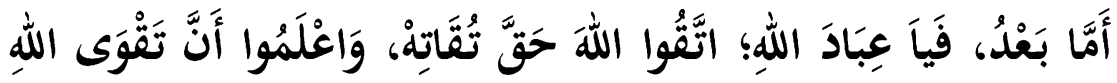

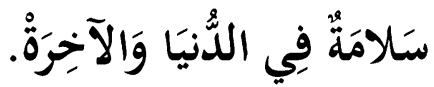

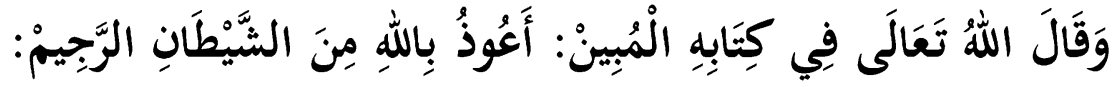

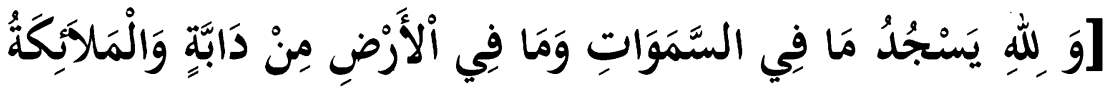

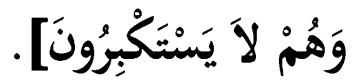

Kaum Muslimin Rahimakumullah

Di Indonesia khususnya banyak satwa telah terjadi kepunahan, dan sisanya terancam punah. Dalam kurun waktu 500 tahun terakhir, sebanyak 844 spesies telah punah tak bersisa, dan sebanyak 16000 
spesies lainnya terancam punah. Harimau Sumatera populasi yang tersisa sekarang hanya sekitar 500 ekor. Elang jawa saat ini hanya sekitar 137-188 pasang burung. Orangutan menurut lembaga IUCN, populasi hanya tersisa beberapa ribu. Populasi gajah Sumatera di alam liar saat ini hanya sekitar 2000-2700 ekor. Badak Jawa status konservasinya telah berada pada fase kritis, di Taman Nasional Ujung Kulon kini populasinya hanya sekitar 40-50 ekor saja. Sebanyak dua pertiga dari total jumlah penyu (tujuh spesies penyu) di seluruh dunia terancam punah seluruhnya pada 2025, sebanyak $50 \%$ dari total populasi kera telah mati, dan setengah dari Sebanyak $40 \%$ dari total flora dan fauna di Indonesia juga akan punah dalam waktu cepat. Ini semua akibat eksploitasi manusia untuk mengeruk keuntungan pribadi.

Kaum Muslimin Rahimakumullah

Kelestarian ekosistem saat ini menjadi salah satu isu sentral mengenai fungsi lingkungan hidup dikarenakan semakin kritisnya keadaan keseimbangan alam yang dilakukan oleh ulah serakah manusia. Pelestarian flora dan fauna telah menjadi hal yang diprioritaskan karena ditemukannya fakta bahwa terdapat beberapa jenis flora dan fauna yang sudah terancam punah kehidupannya di muka bumi ini. Yang perlu diketahui bersama bahwa makhluk hidup termasuk satwa langka yang diciptakan oleh Allah SWT. dalam rangka menjaga keseimbangan ekosistem dan ditundukkan untuk kepentingan kemaslahatan manusia secara berkelanjutan.

Firman Allah SWT.:

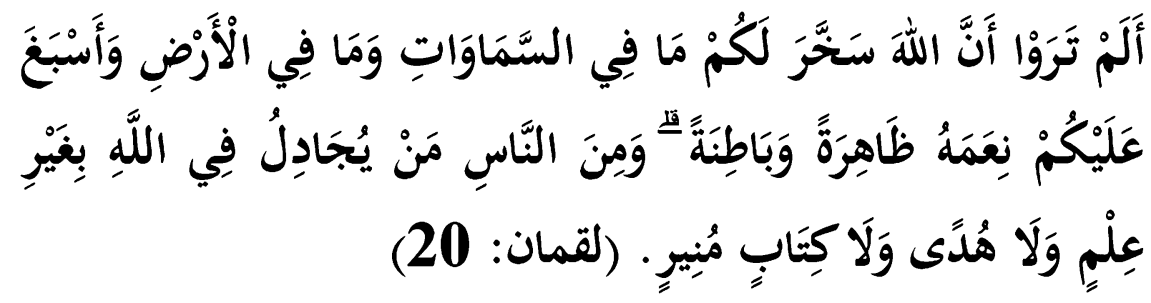


Artinya: "Tidakkah kamu perhatikan Sesungguhnya Allah telah menundukkan untuk (kepentingan)mu apa yang di langit dan apa yang di bumi dan menyempurnakan untukmu nikmat-Nya lahir dan batin. dan di antara manusia ada yang membantah tentang (keesaan) Allah tanpa ilmu pengetahuan atau petunjuk dan tanpa kitab yang memberi penerangan". (QS. Luqman[31]: 20)

Firman Allah SWT.:

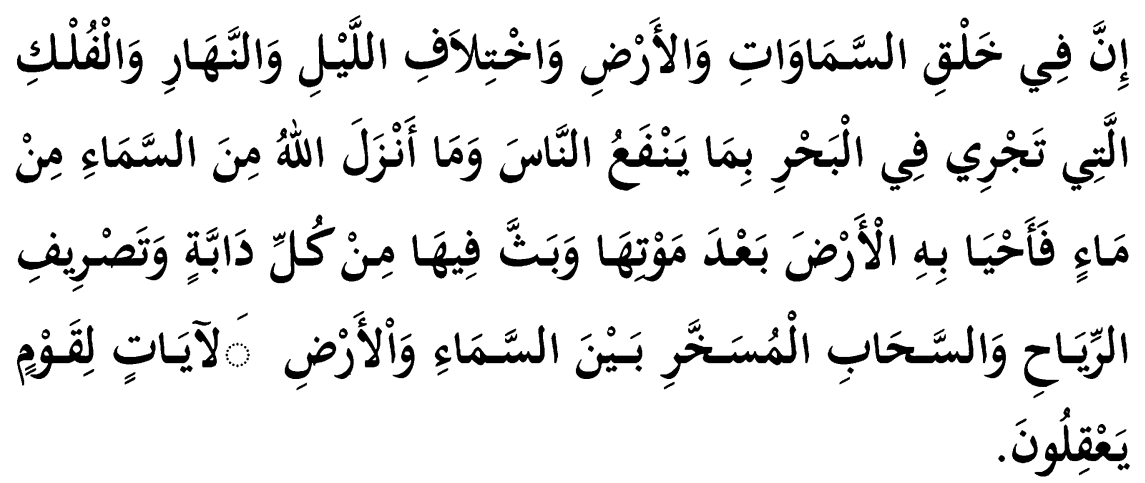

Artinya: Sesungguhnya dalam penciptaan langit dan bumi, silih bergantinya malam dan siang, bahtera yang berlayar di laut membawa apa yang berguna bagi manusia, dan apa yang Allah turunkan dari langit berupa air, lalu dengan air itu Dia hidupkan bumi sesudah mati (kering)-nya dan Dia sebarkan di bumi itu segala jenis hewan, dan pengisaran angin dan awan yang dikendalikan antara langit dan bumi; sungguh (terdapat) tanda-tanda (keesaan dan kebesaran Allah) bagi kaum yang memikirkan. (QS. Al-Baqarah[2]: 164)

Ketika jumlah salah satu komponen dalam makanan meningkat atau menurun secara berlebihan, stabilitas keseluruhan ekosistem akan terganggu. Ketika kita berburu elang secara berlebihan, maka populasi elang akan menurun. Sementara populasi tikus akan meledak karena predator semakin menghilang, sehingga populasi padi akhirnya akan berkurang. Ini tidak baik karena manusia dan hewan 
sama-sama makan padi juga. Selain itu, padi merupakan tempat tinggal bagi organisme penting lainnya dalam bentuk hubungan simbiosis, dan mereka akan hilang juga. Kerugian akhirnya akan kembali kepada manusia sebagai anggota dari jaring makanan besar dalam ekosistem karena kita makan tanaman dan makan apa pun yang memakan tanaman.

Kaum Muslimin Rahimakumullah

Manusia diciptakan oleh Allah SWT sebagai khalifah di muka bumi mengemban amanah dan tanggung jawab untuk memakmurkan bumi dan seisinya. Surat al-Baqarah ayat: 30 :

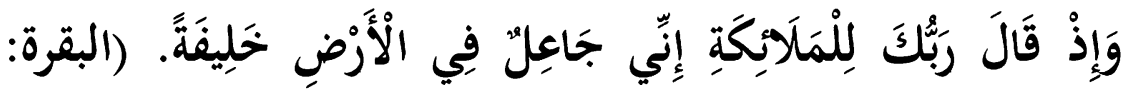

(30

Artinya: "Ingatlah ketika Tuhanmu berfirman kepada Para Malaikat: "Sesungguhnya aku hendak menjadikan seorang khalifah di muka bumi ..." (QS. Al-Baqarah[2]: 30)

Manusia diciptakan oleh Allah SWT. untuk mengemban tugas memakmurkan dan menjaga keseimbangan ekosistem. Sebagai khalifah di muka bumi, manusia memiliki tanggung jawab penuh terhadap kehidupan.

Firman Allah SWT.:

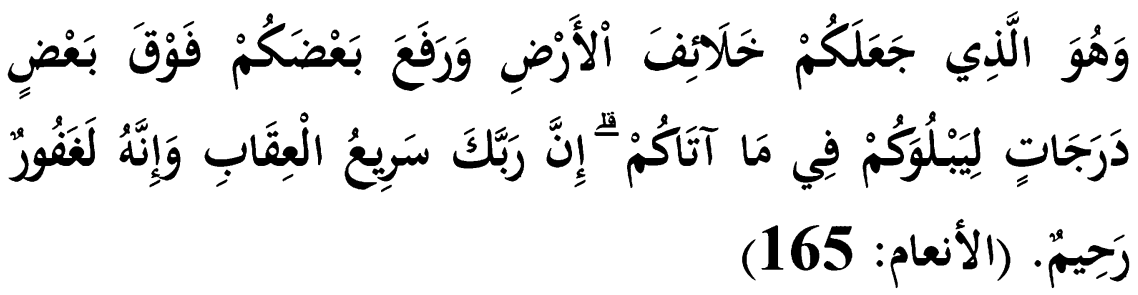


Artinya: "Dia adalah yang menjadikan kamu penguasa-penguasa di bumi dan Dia meninggikan sebahagian kamu atas sebahagian (yang lain) beberapa derajat, untuk mengujimu tentang apa yang diberikan-Nya kepadamu. Sesungguhnya Tuhanmu Amat cepat siksaan-Nya dan Sesungguhnya Dia Maha Pengampun lagi Maha Penyayang"'. (QS. Al-An'am[6]: 165)

Manusia dipercaya Allah SWT. untuk berkuasa atas semua ciptaan-Nya, tetapi bukan berarti mendominasi secara sewenang-wenang. Manusia wajib menjaga dan merawat seluruh ciptaan-Nya.

Kaum muslimin rahimakumullah

Manusia dilarang merusak mata rantai ekosistem, seperti membunuh satwa sebagai awal kepunahannya. Allah SWT. berfirman:

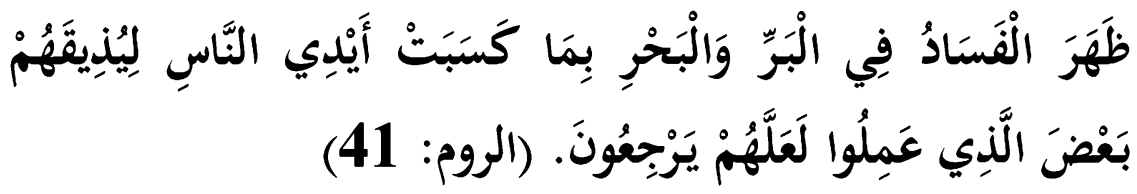

telah nampak kerusakan di darat dan di laut disebabkan karena perbuatan tangan manusia, supaya Allah merasakan kepada mereka sebahagian dari (akibat) perbuatan mereka, agar mereka kembali (ke jalan yang benar). (QS. Al-Ruum[30]: 41).

Bencana di muka bumi ini lebih banyak disebabkan oleh ulah perbuatan manusia yang tidak bertanggung jawab sebagaimana dijelaskan dalam surah Ar-Rum, ayat 41 di atas. Allah SWT. berfirman pula di dalam QS. Ali Imran:

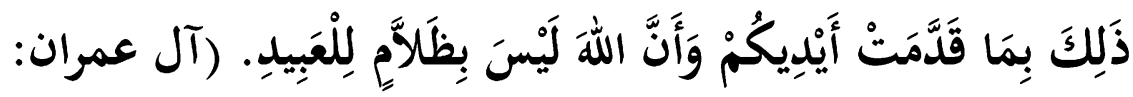


Artinya: "(Adzab) yang demikian itu adalah disebabkan perbuatan tanganmu sendiri, dan bahwasanya Allah sekali-kali tidak menganiaya hamba Nya". (QS. Ali Imran[3]: 182)

Campur tangan umat manusia dalam kerusakan lingkungan cenderung meningkat terutama pada beberapa dasawarsa terakhir. Meningkatnya keruskan lingkungan juga menjadi faktor kepunahan satwa.

Demikian khutbah kali ini, semoga bermanfaat dan bisa menjadi bahan renungan bagi kita semua.

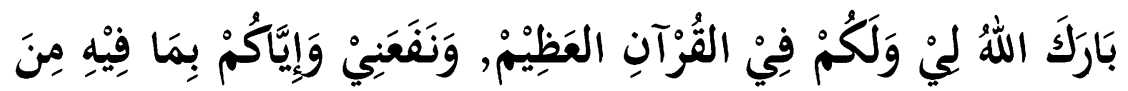

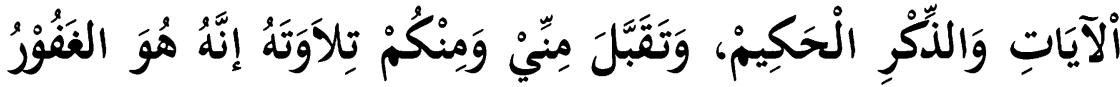

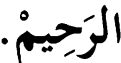




\section{Khuthbah 2}

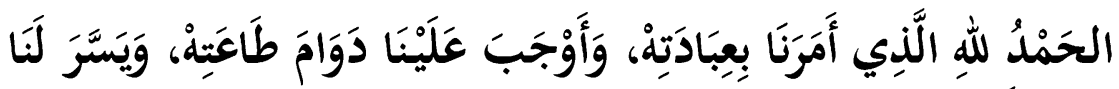

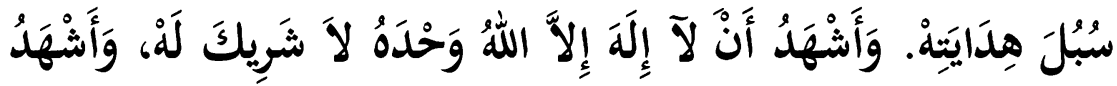

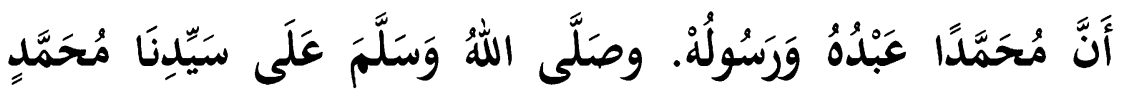

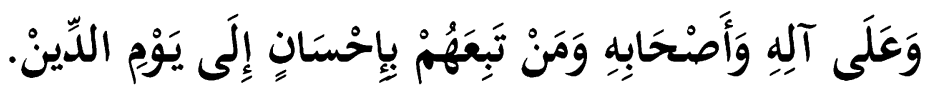

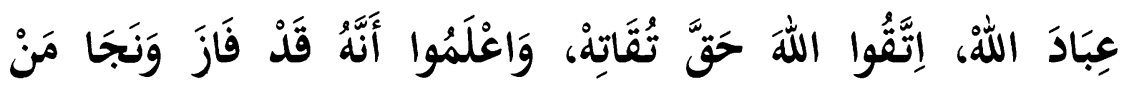

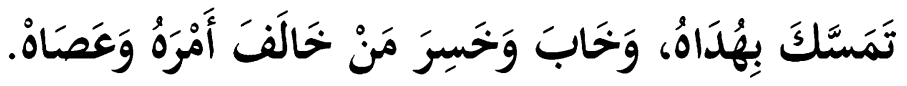

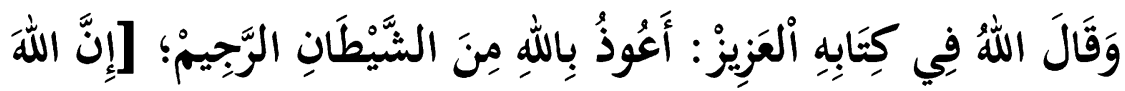

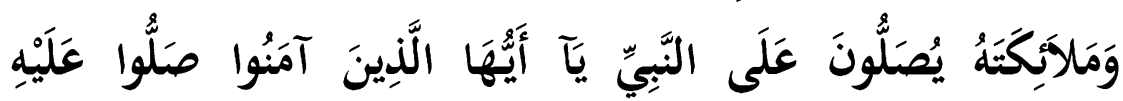
وَسَلُِّوَا تَسْْلِيمًا]

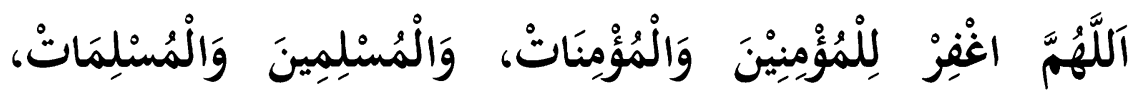

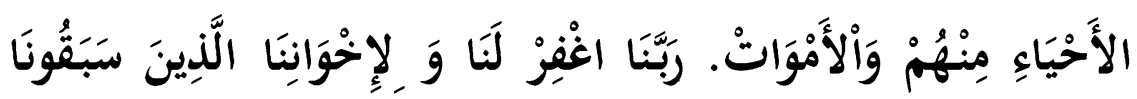

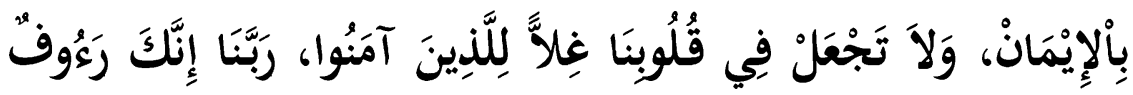

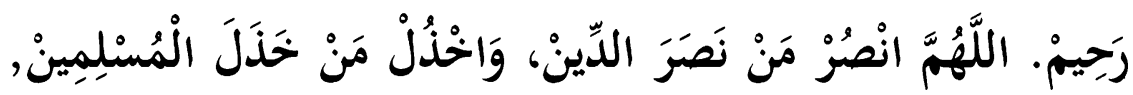

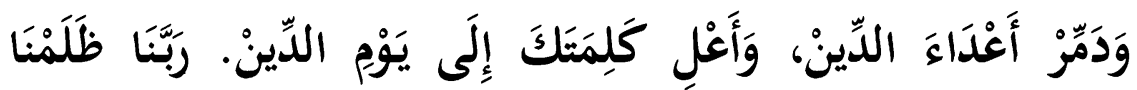




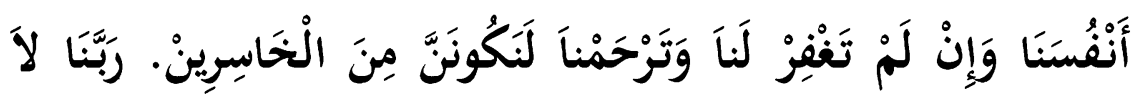

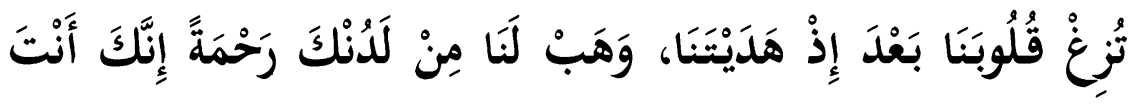

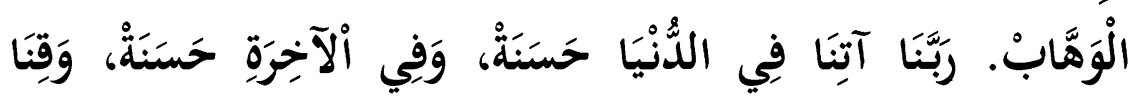

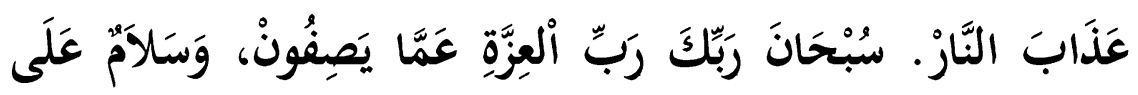

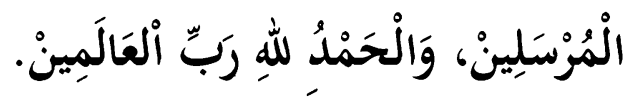

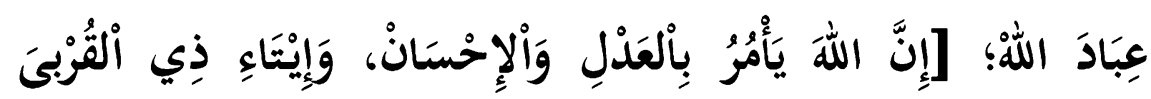

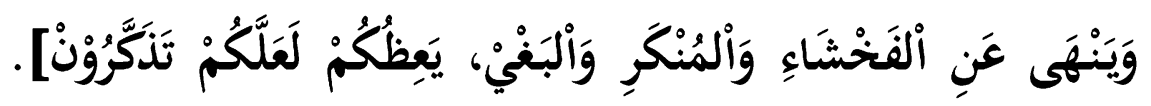

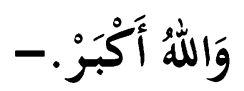




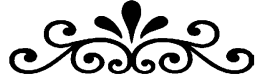 \\ MEMELIHARA SATWA \\ DAN MEMPERDAGANGKANNYA}

\section{Khuthbah 1}

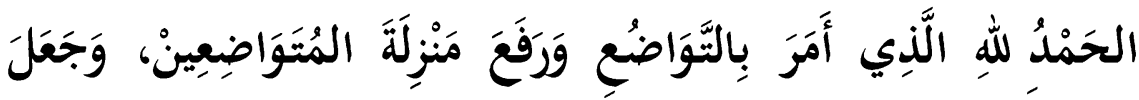

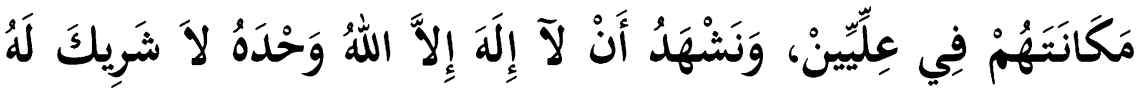

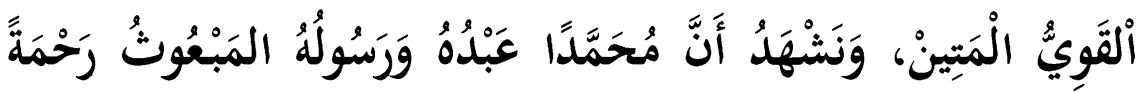

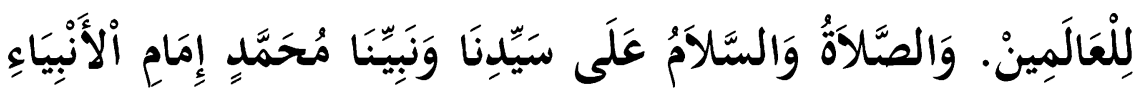

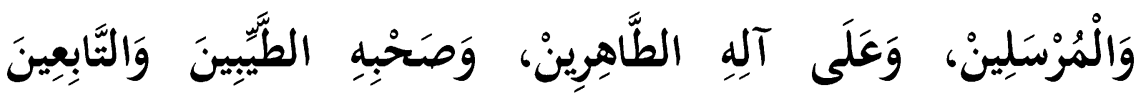
وَتَابِيِِِِمِ الْمَهْدِيِّنْ.

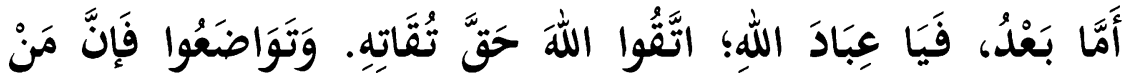

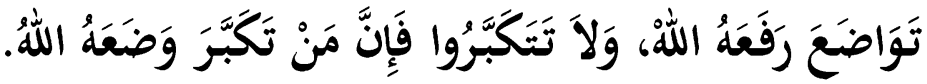

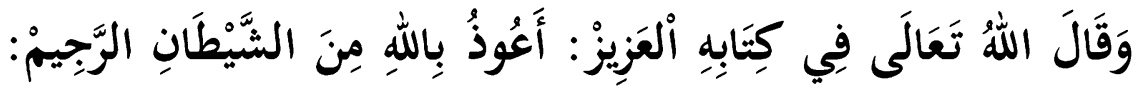

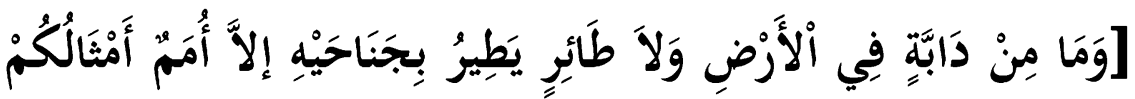

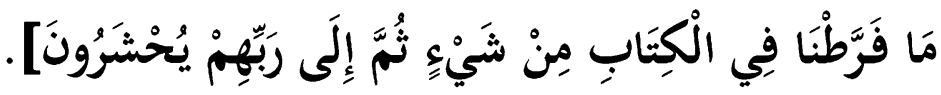


Jama'ah Shalat Jum'at Yang Dimuliakan Allah.

Hewan peliharaan (pet animal) adalah hewan yang dipelihara untuk menjadi sahabat manusia atau memberi kesenangan kepada manusia, misalnya burung, ayam, anjing dan kucing. Tujuan pemeliharaannya berbeda dengan tujuan pemeliharaan hewan ternak (livestock), hewan percobaan laboratorium (laboratory animals), hewan pekerja, atau hewan olah raga yang dipelihara karena alasan-alasan ekonomi. Selain itu masih banyak berbagai hewan pengerat (seperti hamster), burung (seperti kenari, parkit, kakaktua), eptilian (seperti kura-kura, kadal, ular, iguana), ikan (seperti arwana, lohan), dan arthropoda (seperti laba-laba), dan sebagainya.

Apakah diperbolehkan menangkap burung serta memasukkannya ke dalam sangkar, kemudian dipajang di rumah sebagai hiasan seperti burung kakatua dan jenis burung lainnya, atau burung bulbul untuk didengarkan kicauannya, atau memelihara ikan dalam aquarium? Memelihara hewan di lingkungan rumah berarti mengekang kebebasannya itu pada hewan yang biasanya berada di alam bebas, seperti burung. Namun untuk hewan jinak yang kebiasaannya berada di dalam atau di sekitar rumah yang manusia, seperti kucing, kelinci, ayam dan sebagainya. Lalu, bagaimana Islam menanggapi hal ini. Bolehkah manusia memiliki hewan peliharaan untuk diperdagangkan? Dalam kehidupan banyak diantara manusia menginginkan binatang di sekitar mereka yang dimungkinkan untuk dipelihara, diambil manfaatnya untuk kesenangan dan pelipur hati nan gundah. Bagaimanakah hukum memelihara dan memperdagangkan hewan? Selain burung yang memiliki suara, bentuk dan warna yang indah, biasanya hewan peliharaan itu bisa berupa kucing, iguana, kelinci, ayam dan lainnya.

Jama'ah Shalat Jum'at Yang Dimuliakan Allah.

Memelihara burung merpati untuk didengarkan kicauannya diperbolehkan, mengkonteskannya tanpa taruhan hukumnya makruh, 
dan dengan taruhan hukumnya haram. Penjelasan ulama figh di dalam beberapa karyanya, bahwa memelihara merpati untuk bertelur, berkembang biak, kesenangan semata, atau untuk kurir surat, hukumnya mubah, sedangkan untuk permainan hukumnya makruh" sebagaimana di dalam Asnaa al-Mathaalib, Jilid IV, hlm 344. Demikian pula dijelaskan, bahwa tidak dibolehkan mengadu hewan seperti sapi, burung, dan sejenisnya, bila dengan taruhan hukumnya haram, dan bila tanpa taruhan hukumnya boleh" sebagaimana di dalam Al-Baajuuri, Jilid II, hlm 307.

Hal tersebut tidak berdosa, jika anda tidak berbuat zhalim, dan hendaklah anda memperlakukannya dengan baik dalam hal memberi makanan dan minumannya. Baik binatang peliharaan tersebut berupa burung kakatua, burung dara, ayam, atau binatang peliharaan lainnya dengan syarat harus diperlakukan dengan baik dan tidak menzhaliminya, baik binatang peliharaan itu dipelihara di dalam kolam, sangkar atau aquarium seperti ikan misalnya. Sesungguhnya Allah SWT. Maha Pelindung lagi Maha Penolong. Dari keterangan di atas dapat ditarik kesimpulan bahwa memelihara burung itu hukumnya diperbolehkan, meskipun hanya sekedar untuk menikmati keindahan suaranya, bulu-bulunya atau sekedar untuk bersenang-senang asalkan pemilik burung merawatnya dengan baik, dengan mencukupi keperluan makanan dan minumannya. Sedangkan mengawinkan hewan tersebut bukanlah suatu keharusan bagi pemiliknya. Dapat kita simpulkan bahwa kita boleh-boleh saja merawat burung dalam sangkar tetapi tak boleh lupa untuk tetap menjaga makanan dan minuman bagi burung tersebut dan tetap memperhatikan kesehatannya agar tidak sampai menyiksa burung tersebut.

Jama'ah Shalat Jum'at Yang Dimuliakan Allah.

Hukum memelihara hewan secara syar'i adalah boleh, selama terpenuhi 4 (empat) syarat sebagai berikut: 
Pertama, hewan yang dipelihara tidak najis dzatnya (najis 'ain/hissi), seperti anjing dan babi. Memelihara hewan piaraan yang najis tidak boleh, karena termasuk memanfaatkan najis yang dilarang secara syar'i. Mahmud Abdul Lathif 'Uwaidhah di dalam Al-Jami' li Ahkam al-Shalah, jilid I, hIm 115 menyebutkan kaidah figh:

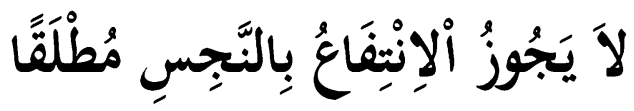

Artinya: "Secara mutlak tidak boleh memanfaatkan najis".

Hewan najis boleh dipelihara, bila terdapat suatu sebab berdasarkan nash syar'i yang membolehkannya, misalnya memelihara anjing untuk menjaga ternak atau untuk dilatih berburu.

Nabi SAW. bersabda:

عَنْ عَبْدِ اللهِهِنْ عُمَرَ، قَالَ: قَالَ رَسُولُ اللهِ صَلَّى اللهُ عَلَيْهِ وَسَلَّمَ:

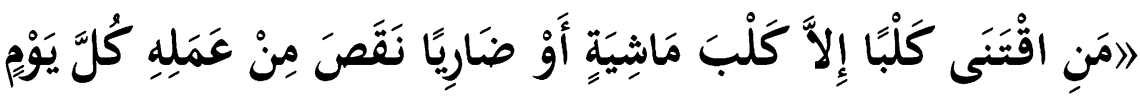
قِيرَاطَانِ《ِ رواه البخحاري ومسلم

Artinya: Dari Abdullah ibn 'Umar ra., ia berkata: "Siapa saja memanfaatkan anjing selain anjing penjaga ternak atau anjing dilatih untuk berburu, maka pahala amal shalihnya setiap hari berkurang dua qirath". (HR. Bukhari dan Muslim)

Kedua, hewan yang dipelihara wajib diberi makan dan minum yang cukup. Memelihara hewan tanpa memberinya makan dan minum yang cukup hukumnya haram. Dalilnya sabda Nabi SAW: "Seorang perempuan masuk neraka karena seekor kucing yang diikatnya. Perempuan itu tidak memberikannya makan dan tidak pula melepaskannya agar dapat memakan binatang-binatang bumi". (HR Bukhari no. 3140; Muslim no. 2242). 
Ketiga, hewan yang dipelihara tidak menimbulkan bahaya (dharar) bagi manusia, seperti singa, beruang, atau buaya yang dipelihara dalam kandang secara tak aman bagi manusia. Jika diletakkan di kandang yang aman bagi manusia, hukumnya boleh.

Nabi SAW. bersabda:

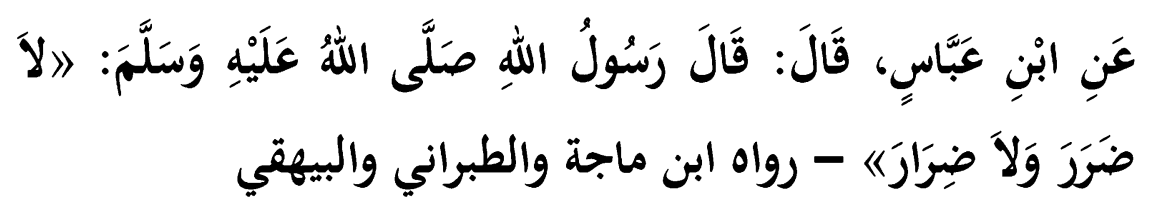

Artinya: Dari Ibnu 'Abbâs ra, ia bersabda: Rasulullah SAW:"Tidak boleh terjadi kemudaratan dan tidak tidak boleh pula menimbulkan mudarat". (H.R. Ibnu Majah, Thabrani dan al-Baihaqi).

Keempat, hewan yang dipelihara tidak menjadi sarana untuk perbuatan yang haram. Misalnya, memelihara ayam jantan yang akan digunakan untuk perjudian. Dalam hal ini, Taqiyuddin An-Nabhani di dalam Muqaddimah ad-Dustur, jilid I, hlm 85 menyebutkan kaidah fiqih:

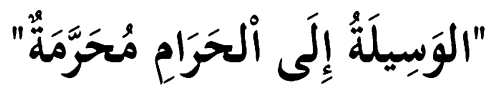

Artinya: "segala sarana untuk hal yang haram adalah haram".

Hewan yang boleh dipelihara tidak disyaratkan halal dimakan (alma 'kuul). Oleh karena itu, memelihara kucing dibolehkan karena bukan hewan najis sebagaimana hadits riwayat Abu Dawud dan Tirmidzi, meskipun termasuk hewan yang haram dimakan sebagaimana hadits riwayat Ibnu Majah dari Jabir ra. no. 3250.

Memperdagangkan hewan piaraan, hukumnya boleh jika hewannya halal dimakan, misalnya kelinci, kuda, tupai, dsb. Jika hewannya haram dimakan, seperti anjing, babi, kucing, ular, singa, burung elang, dsb, maka memperdagangkannya haram. Hal ini sesuai kaidah figh 
di dalam Al-Syakhshiyyah Al-Islamiyyah, 2/287 oleh Taqiyuddin AnNabhani:

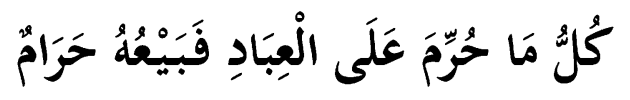

Artinya: "Setiap benda yang diharamkan bagi para hamba Allah, maka menjualnya adalah haram".

Demikian khutbah kali ini, semoga bermanfaat dan bisa menjadi bahan renungan bagi kita semua.

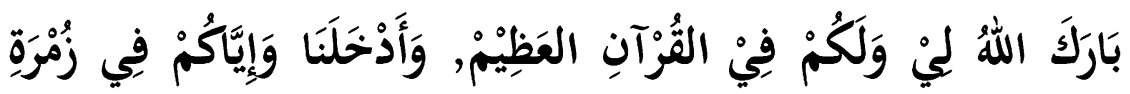

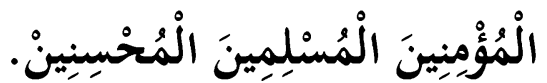




\section{Khuthbah 2}

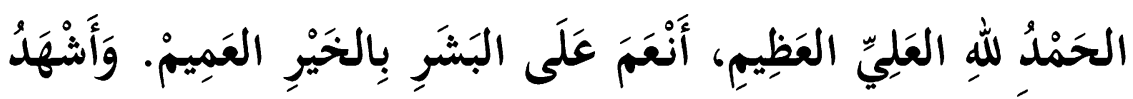

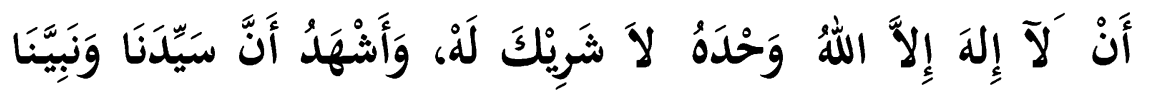

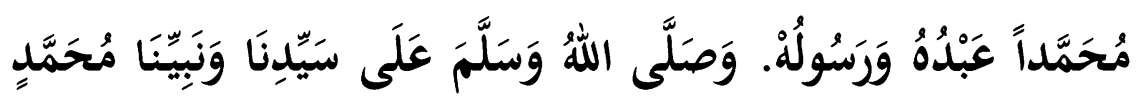

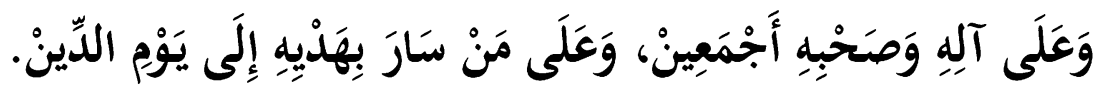

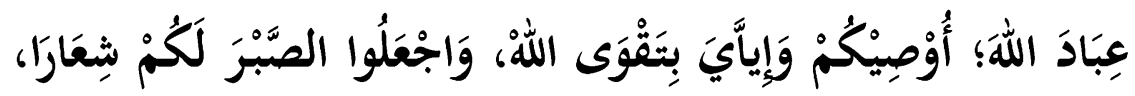

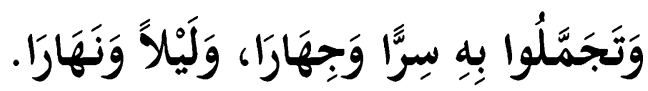

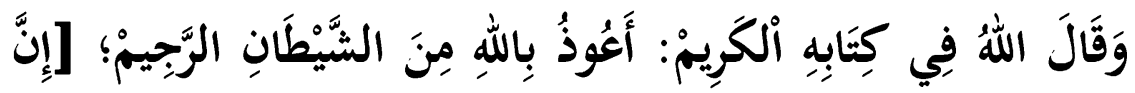

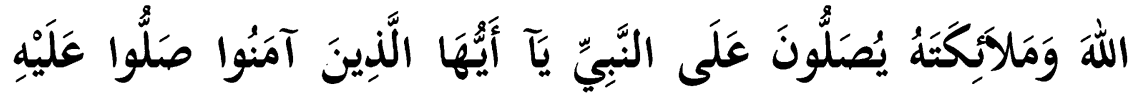

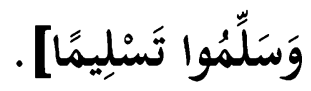

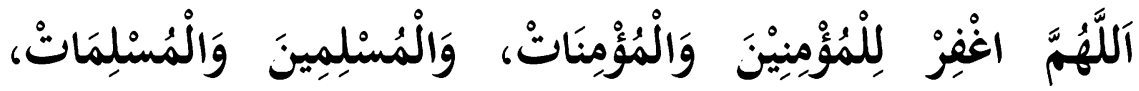

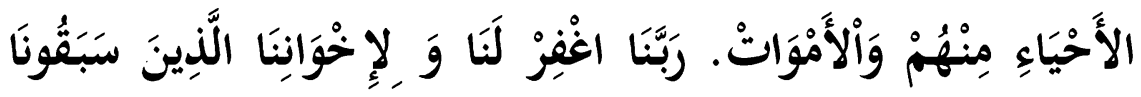

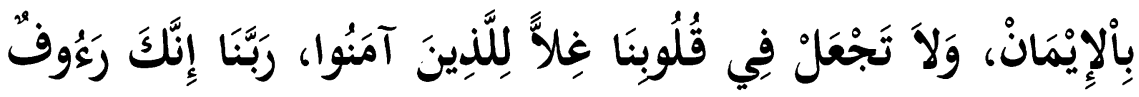

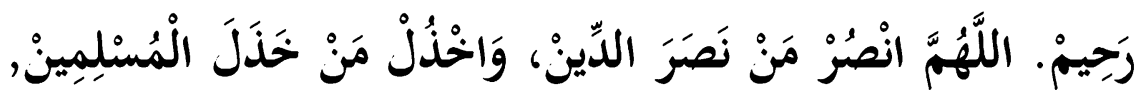

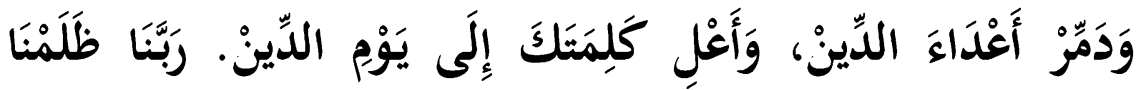




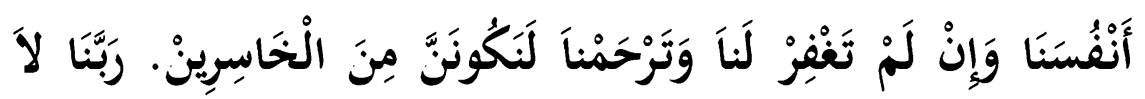

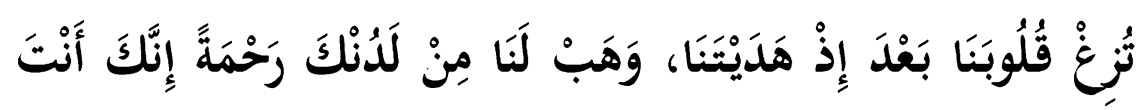

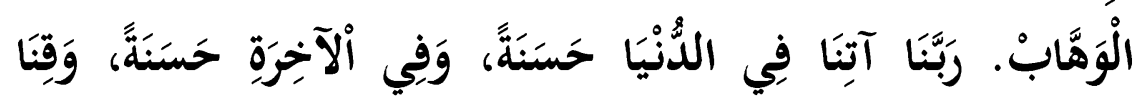
عَذَابَ النَّارْ

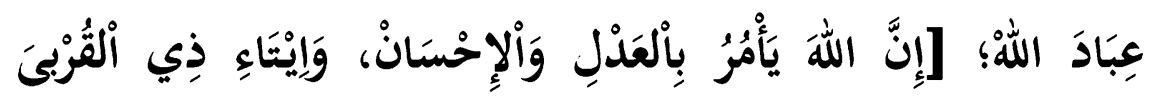

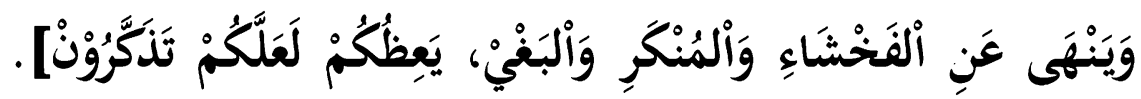
وَالله أَكَبْرَ. -- 


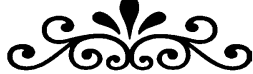

\section{MENGASIHI MAKHLUK ALLAH ADALAH IBADAH}

\section{Khuthbah 1}

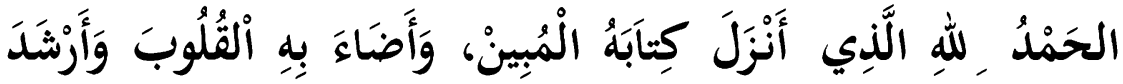

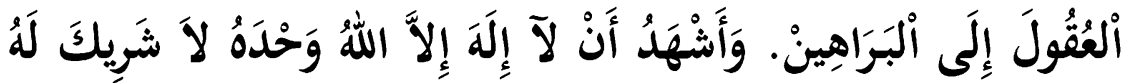

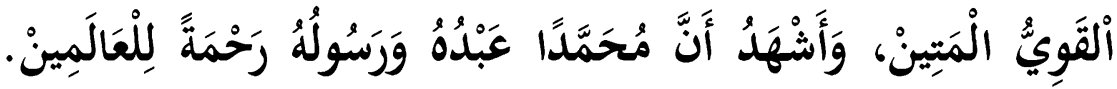

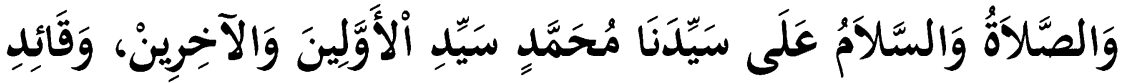

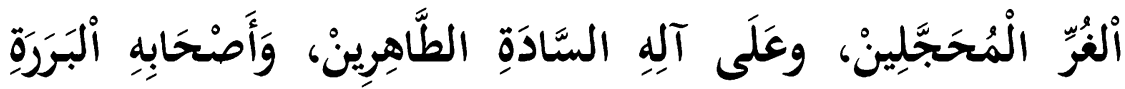

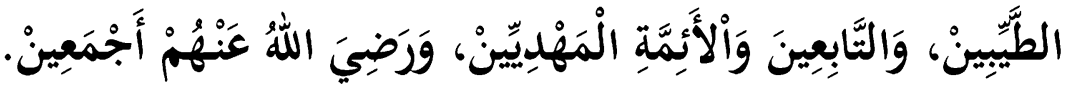

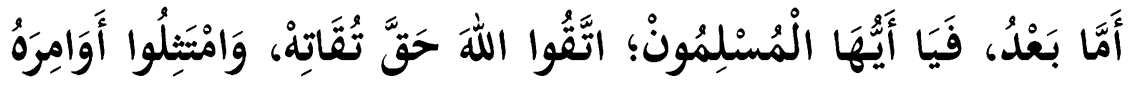

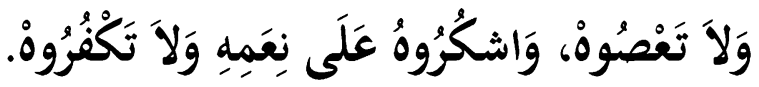

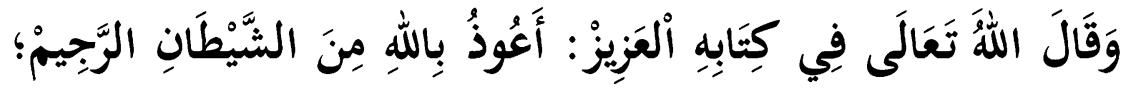

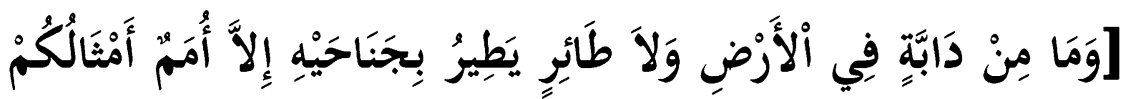

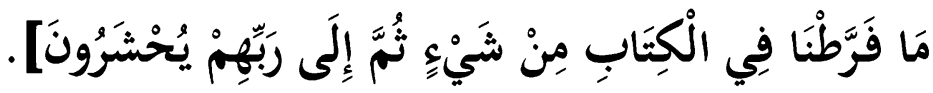

Ma’asyirah Muslimin, Rahimakumullah

Al-Quran merupakan kitab suci yang tidak hanya mengatur ibadah bagi umat Islam, tapi juga menjadi sumber inspirasi dan motivasi 
dalam bekerja dan berkarya, menjadi pedoman dalam berbagai bidang, seperti sosial kemasyarakatan, politik, ekonomi, budaya, termasuk juga menjadi pedoman bagaimana manusia berinteraksi dan memperlakukan sesama makhluk Allah SWT. di muka bumi ini. Agama dibangun di antaranya untuk menunaikan hak-hak Allah dan hak-hak para makhluk-Nya. Hak Allah adalah hak untuk disembah dan tidak disekutukan dengan ciptaan-Nya. Adapun hak makhluk adalah berbuat baik, berakhlak mulia, dan tidak menyakiti apalagi membinasakan makhluk lainnya dengan semena-mena. Bahkan mengasihani mereka termasuk ibadah.

Di dalam kitab suci Al-Quran, Allah SWT. memerintahkan kepada kita untuk berbuat kebajikan kepada sesama makhluk hidup di bumi ini. Perintah tersebut termaktub dalam surat Al-An'am ayat 38:

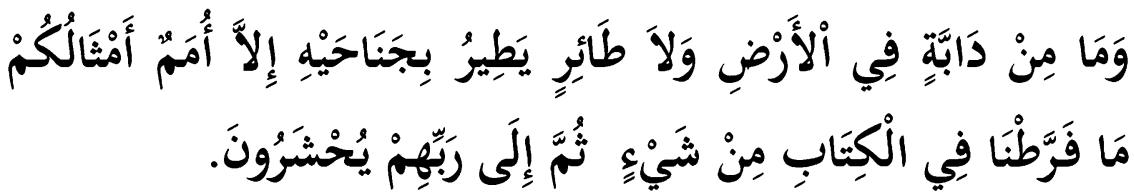

Artinya: "Dan tiadalah binatang-binatang yang ada di bumi dan burung-burung yang terbang dengan kedua sayapnya, melainkan (semua itu adalah) umat seperti kamu. Tiadalah Kami melalaikan sesuatupun dalam Al-Kitab (Lauh Mahfudh), kemudian kepada Tuhanlah mereka dihimpunkan". (QS. Al-An'am [6] : 38)

Menurut Mujahid, seorang ulama besar dalam bidang tafsir, bahwa makna umamun dalam ayat di atas ialah berbagai macam jenis yang nama-namanya telah diketahui. Adapun menurut Qatadah yang juga ulama besar dalam bidang tafsir, bahwa hewan itu umat, manusia itu umat, dan jin itu umat. Maka dari itu, kita harus memperlakukan mereka semua dengan baik, sebagaimana diajarkan di dalam Al-Quran.

Menurut suatu kisah, setelah sayyidina Umar ra. wafat, banyak masyarakat Madinah bermimpi bertemu dengannya. Mereka bertanya 
tentang keadaannya setelah wafat. Kemudian sayyidina Umar ra. menjawab, bahwa Allah telah mengampuni semua dosa dan kesalahannya. Mereka bertanya lagi tentang apa yang menyebabkan dosa-dosanya diampuni. Apakah karena kedermawannya, kezuhudannya, atau karena keadilannya. Sayyidina Umar ra. menjawab, bahwa yang menyebabkan ia diampuni oleh Allah SWT. adalah bukan karena itu semua, namun karena ia mengasihi seekor burung pipit dan memberikan hak-haknya. Pada suatu ketika sayyidina Umar ra. semasa hidupnya pernah berjalan di lorong-lorong Kota Madinah, ia melihat anak kecil yang sedang menjadikan mainan seekor burung pipit. Karena rasa kasihan, lalu burung pipit itu dibeli olehnya, dan kemudian dilepaskannya. Dalam hadits riwayat Thabrani, Rasulullah SAW. bersabda :

Artinya: "Sayangilah makhluk yang ada di bumi, niscaya para Malaikat di langit akan menyayangimu".

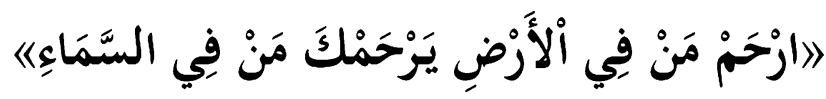

Kaum Muslimin Yang Dirahmati Allah

Ada banyak jenis makhluk Allah di alam semesta ini, namun hanya empat makhluk yang ada keterkaitan erat dengan manusia, yaitu hewan, tumbuhan, alam (bumi) dan sesama manusia. Lalu bagaimana cara kita mengasihi makhluk-makhluk Allah tersebut agar keterkaitan keempatnya dengan manusia berjalan dengan baik.

\section{Mengasihi Hewan.}

Sebagaimana fatwa Majelis Ulama Indonesia (MUI) nomor 04 tahun 2014 tentang "Pelestarian Satwa Langka Untuk Menjaga Keseimbangan Ekosistem", kita sebagai umat Islam dihimbau untuk ikut berperan aktif dalam menjaga dan melestarikan hewan, terutama jenis hewan yang terancam punah. Karena salah satu upaya untuk mengasihi hewan adalah dengan menjaga kehidupan dan melestarikannya. Dalam surat Yasin ayat 71-72, Allah SWT. berfirman: 


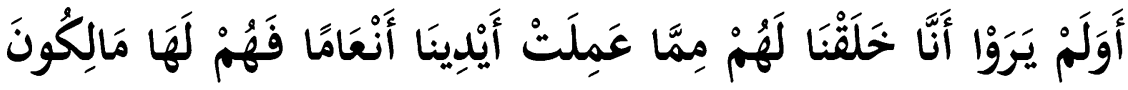

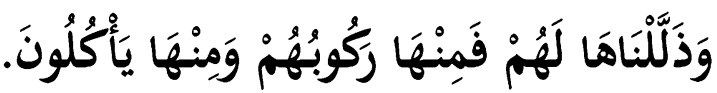

Artinya: "Dan apakah mereka tidak melihat bahwa sesungguhnya Kami telah menciptakan binatang ternak untuk mereka yaitu sebahagian dari apa yang telah Kami ciptakan dengan kekuasaan Kami, lalu mereka menguasainya? Dan Kami tundukkan binatang-binatang itu untuk mereka; sebahagiannya menjadi tunggangan mere$k a$, dan sebahagiannya mereka makan". (QS. Yasin [36]: 71-72)

Ayat di atas menegaskan, bahwa hewan sangat bermanfaat bagi manusia. Oleh karena itu, kita tidak boleh memanfaatkannya secara berlebihan, tidak boleh pula salah memanfaatkannya. Kita musti menjaga keutuhannya, melestarikan populasinya, dan mempertahankan kelangsungan ekosistemnya.

Sebuah kisah dalam hadits Nabi SAW.:

عَنْ أَبِي هُرَيْرَةَ رَضِيَ اللهُ عَنْهُ: أَنَّ رَسُولَ اللهِهِ صَلَّلى اللهُ عَلَيْهِ وَسَلَّمَ

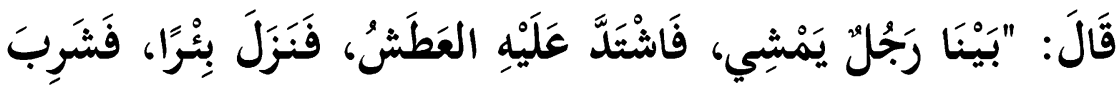

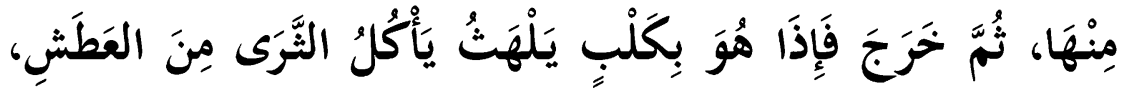

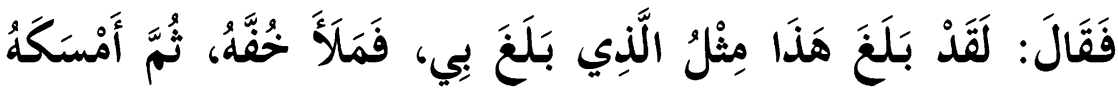

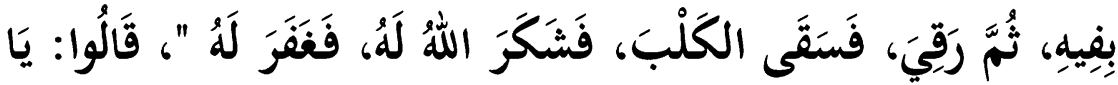

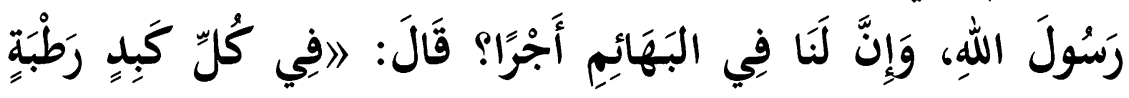
أَجْرُ ، . رواه البخاري ومسلم

Artinya: "Dari Abu Hurairah ra. bahwasanya Rasulullah SAW. bersabda: "Ketika seorang lelaki sedang berjalan dan merasa sangat da- 
haga, lalu ia masuk ke dalam sumur dan meminum air di dalamnya kemudian keluar. Tiba-tiba muncul seekor anjing menjilat-jilat sambil mengisap tanah basah karena kehausan. Lalu lelaki itu berkata: "Anjing ini kehausan seperti yang saya alami". Lalu ia mengisi sepatunya dengan air, dan ia membawanya naik dengan mulut, kemudian memberikannya untuk minum kepada anjing itu. Lalu Allah. memuji amal baiknya dan mengampuninya". Para sahabat bertanya: "Wahai Rasulullah, apakah kita mendapat pahala jika berbuat baik kepada binatang?". Beliau menjawab: "Berbuat baik terhadap setiap binatang adalah pahala. (HR. Bukhari dan Muslim).

Pengertian hadits ini tidak terbatas kepada anjing saja, tetapi mencakup semua binatang. Seperti kucing, onta, lembu, kambing, ayam dan lain sebagainya. Berbuat baik kepada binatang, mencakup segala sesuatu yang dapat menghindarkannya dari penderitaan, seperti haus, lapar, sakit, panas, kerja berat, dan sebagainya. Demikian pula memberikan sesuatu yang bermanfaat baginya, seperti makanan, minuman, dan kesempatan istirahat. Perbuatan baik tersebut mendatangkan pahala dari Allah SWT.

\section{Mengasihi Tumbuhan.}

Allah berfirman dalam surat Thaha ayat 53 .

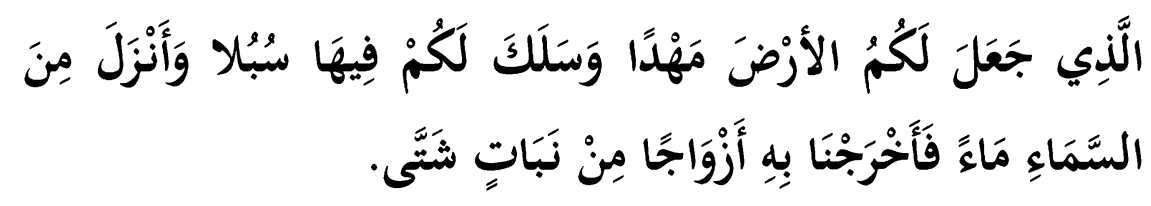

Artinya: "Yang telah menjadikan bagimu bumi sebagai hamparan dan yang telah menjadikan bagimu di bumi itu jalan-jalan, dan menurunkan dari langit air hujan. Maka Kami tumbuhkan dengan air hujan itu berjenis-jenis dari tumbuh-tumbuhan yang bermacam-macam". (QS. Thaaha [20]: 53) 
Kalau kita amati, banyak hutan-hutan kita yang ditebangi oleh orang-orang yang tidak bertanggung jawab. Kalau seandinya itu terus menerus, maka saat hujan kita akan terkena banjir sedangkan saat kemarau kita akan kekeringan dan kekurangan air, itu disebabkan semakin menipisnya jumlah pohon kita.

Untuk itu, kita sebagai muslim yang taat sudah semestinya menjaga dan memelihara kelestarian hutan dan tumbuhan kita, agar keseimbangan kehidupan kita berlangsung dengan baik. Sebagaimana makhluk Allah lainnya, tumbuhan juga wajib kita kasihi, yaitu dengan cara menjaganya.

\section{Mengasihi alam (bumi).}

Allah SWT bersabda dalam surat Al A'raf ayat 56:

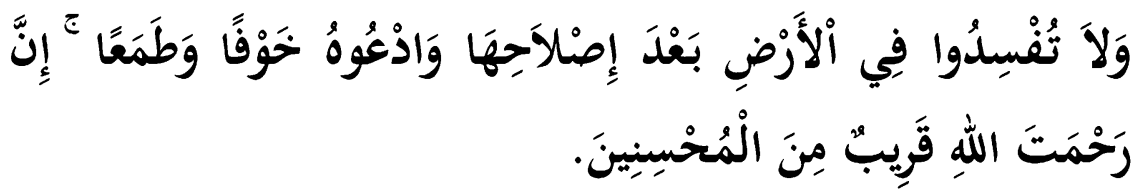

Artinya: "Dan janganlah kamu membuat kerusakan di muka bumi, sesudah (Allah) memperbaikinya dan Berdoalah kepada-Nya dengan rasa takut (tidak akan diterima) dan harapan (akan dikabulkan). Sesungguhnya rahmat Allah Amat dekat kepada orang-orang yang berbuat baik". (QS. Al A'raf [7]: 56)

Allah Ta'ala melarang kita dari melakukan perusakan bumi atau alam ini, setelah dilakukan perbaikan atasnya. Karena jika berbagai macam urusan sudah berjalan dengan baik dan setelah itu terjadi perusakan, maka yang demikian itu lebih berbahaya dan itu akan menimbulkan bencana bagi umat manusia.

Sekarang kita lihat, kondisi alam kita yang semakin hari semakin memprihatinkan. Bagaimana tidak? Setiap harinya, sumber daya alam kita dikeruk habis-habisan. Kerusakan terjadi di mana-mana, 
bukan hanya di darat tetapi juga di laut. Batu bara, emas, minyak, tanah, dan hasil alam lainnya diambil oleh orang-orang yang hanya memikirkan keuntungan pribadi atau kelompoknya, serta tidak memikirkan sama sekali apa dampaknya bagi masyarakat dan lingkungan.

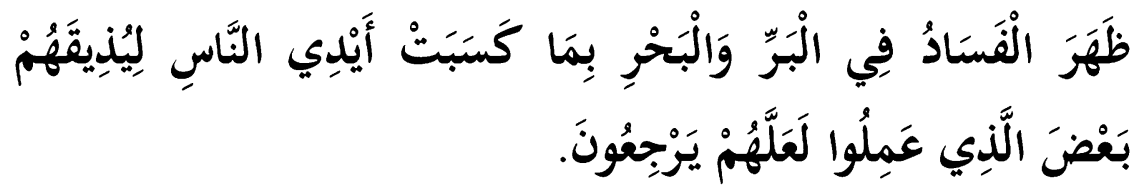

Artinya: "Telah nampak kerusakan di darat dan di laut disebabkan karena perbuatan tangan manusi, supaya Allah merasakan kepada mereka sebahagian dari (akibat) perbuatan mereka, agar mereka kembali (ke jalan yang benar)". (QS. Ar-Ruum [30]: 41).

Oleh karenanya, kita harus lebih memperhatikan lingkungan dan kondisi alam kita kalau kita tidak ingin suatu saat nanti bencana akan menimpa kita. kita harus lebih sadar terhadap tindakan mengeksploitasi alam yang tidak memperhatikan dampak dan kerugiannya.

\section{Mengasihi sesama manusia}

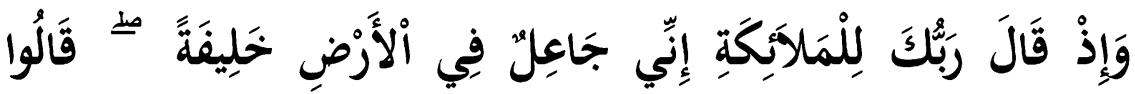
أَتَجْعَلُ فِيهَا مَنْ يُفْسِلُ فِيهَا وَيَنْفِكُ اللَّمَاءَ وَنَحْنُ نُسَبِّحُ بِحَمْلِكِكَ

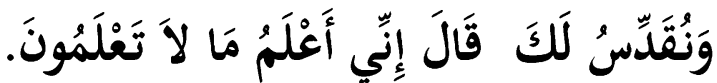

Artinya: "Ingatlah ketika Tuhanmu berfirman kepada para malaikat: "Sesungguhnya Aku hendak menjadikan seorang khalifah di muka bumi." Mereka berkata: "Mengapa Engkau hendak menjadikan (khalifah) di bumi itu orang yang akan membuat kerusakan padanya dan menumpahkan darah, Padahal kami senantiasa bertasbih dengan memuji Engkau dan mensucikan Engkau?" Tuhan berfirman: 
"Sesungguhnya aku mengetahui apa yang tidak kamu ketahui." (QS. Al-Baqarah [2]: 30)

Sebagai khalifah Allah di muka bumi ini, manusia memiliki tanggung jawab yang besar. Mereka memiliki tugas untuk memakmurkan dan membuat dunia aman, tentram, dan sentosa. Namun faktanya dengan melihat pada realitas pengalaman sejarah umat manusia dari masa ke masa memang tidak sedikit golongan manusia yang suka berperang, hobi menumpahkan darah atas sesama manusia hanya dengan alasan untuk menguasai kekayaan hasil bumi.

Kita berharap semoga kita bisa melaksanakan dan menjalankan tugas kita sebagai khalifah di muka bumi ini dengan baik sebagaimana yang dikehendaki oleh Allah SWT. agar berhasil menunaikan tugas tersebut, maka wajib bagi kita untuk senantiasa berpegang teguh kepada Al Quran, sunnah nabi, dan pendapat-pendapat para ulama. Dengan menaati syariat Islam, manusia akan menunaikan tugasnya sebagai khalifah dengan sebaik-baiknya sesuai dengan apa yang dimandatkan oleh Allah SWT. Bukankah makna dari Islam adalah damai, sedangkan damai tidak akan diperoleh kecuali dengan saling mengasihi dan menyayangi antar sesama. Semoga kita bisa menyayangi semua makhluk-Nya, termasuk tumbuhan dan hewan sebagaimana dilakukan oleh sayyidina Umar ra. Karena mengasihi makhluk-Nya merupakan ibadah.

Demikian khutbah kali ini, semoga bermanfaat dan bisa menjadi bahan renungan bagi kita semua.

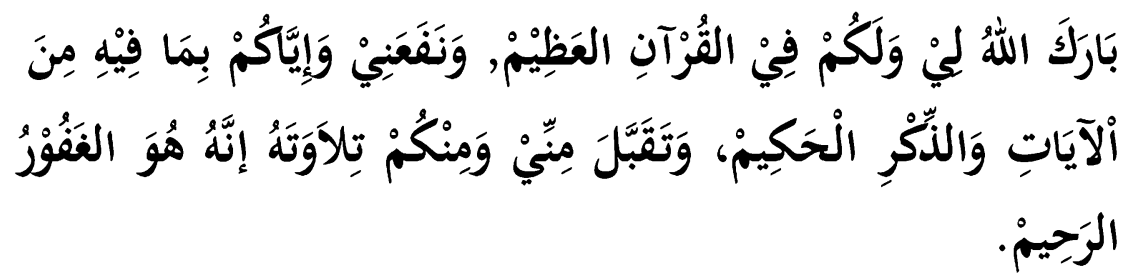




\section{Khuthbah 2}

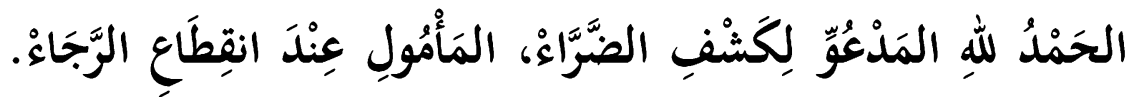

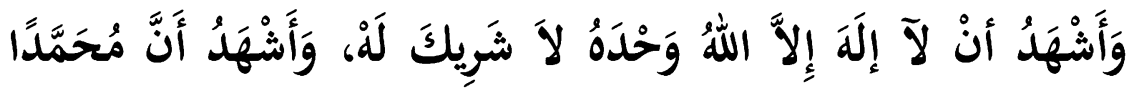

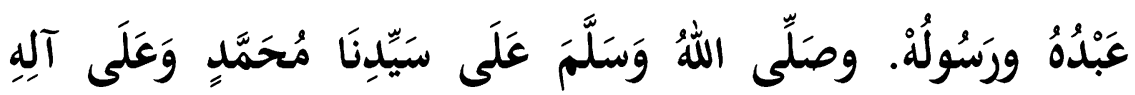

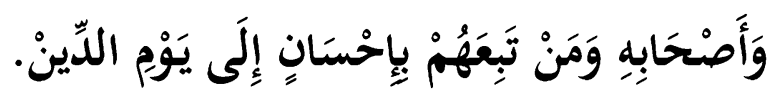

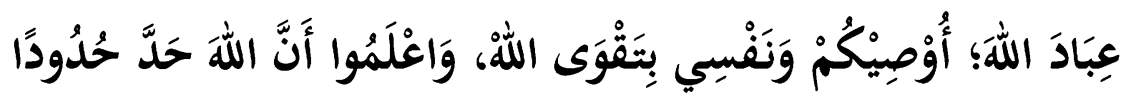

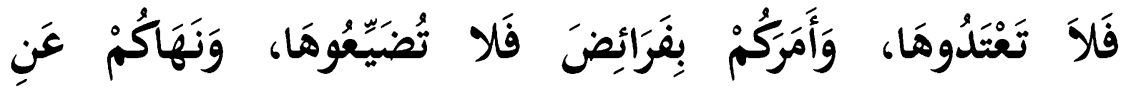
المُنْكَراتِ فَاجَتَبُْوهَا.

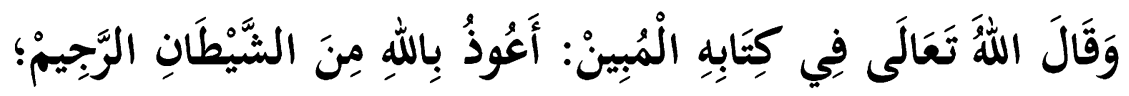

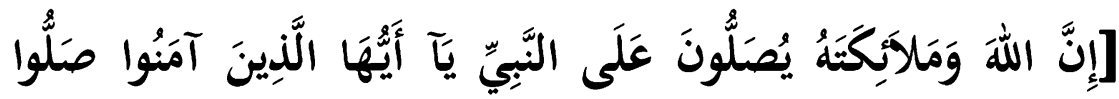

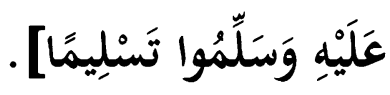

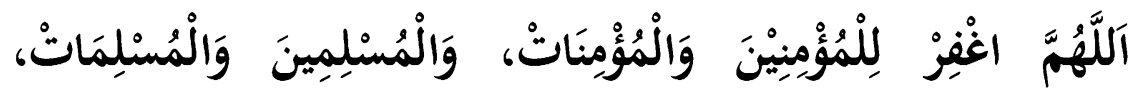

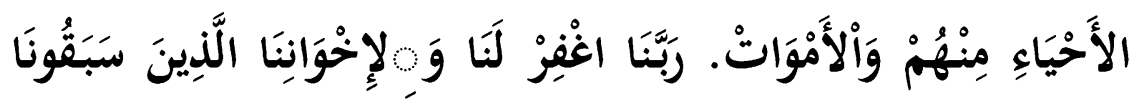

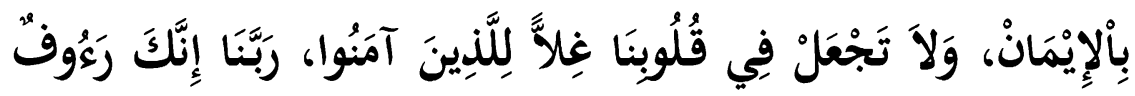

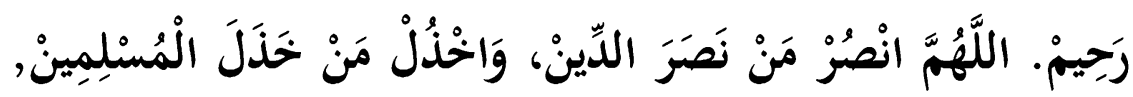




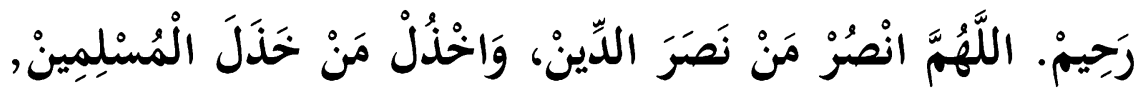

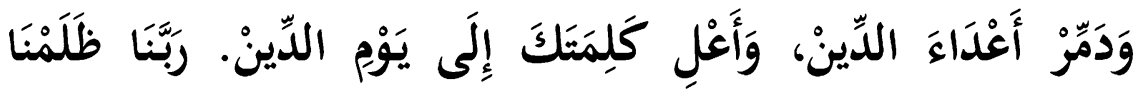

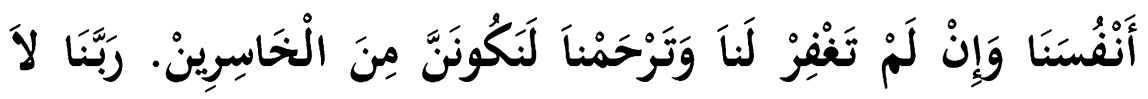

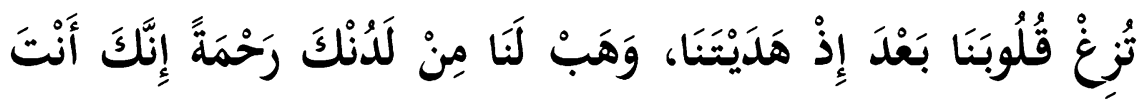

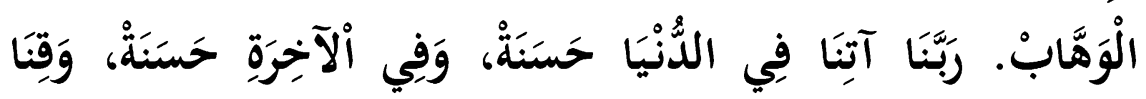

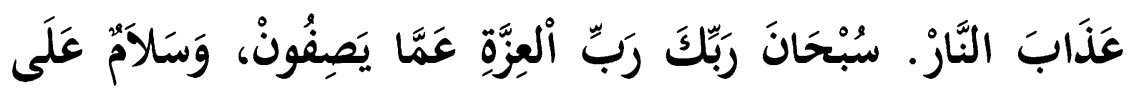

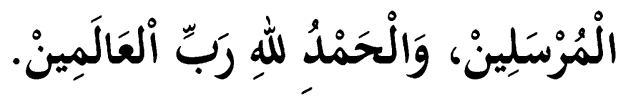

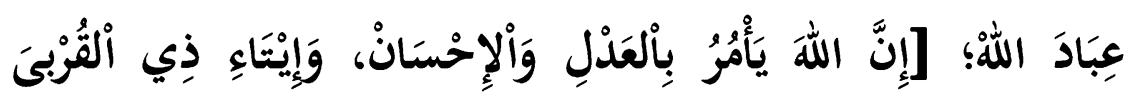

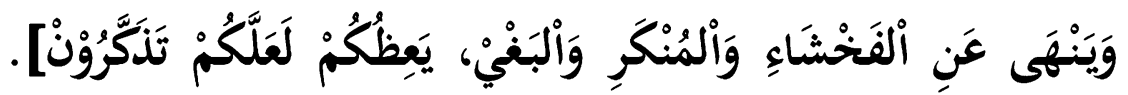

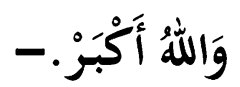




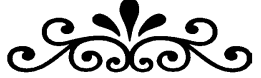 \\ SELURUH MAKHLUK \\ TERMASUK SATWA BERTASBIH}

\section{Khuthbah 1}

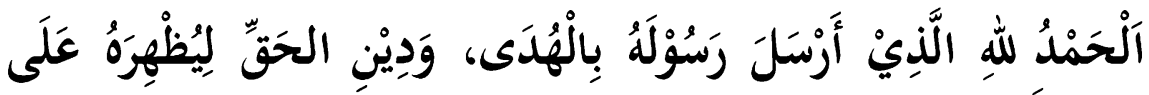

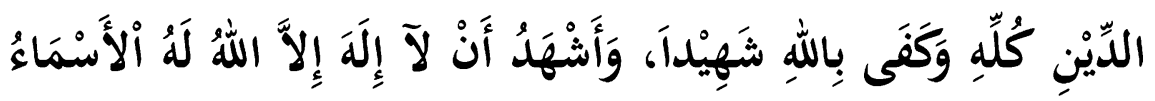

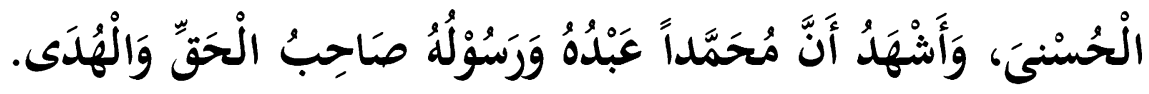

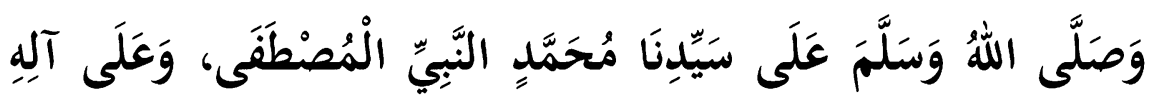

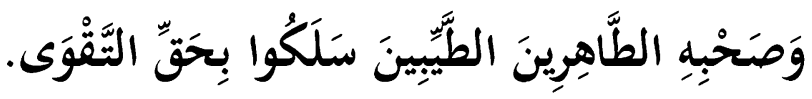

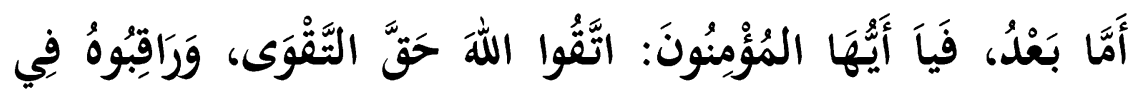

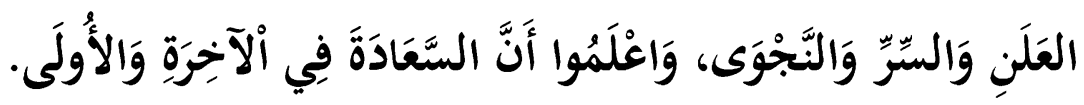

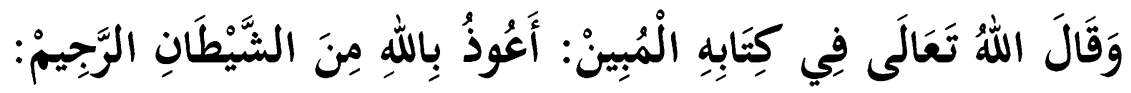

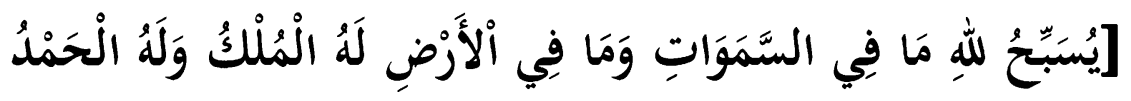

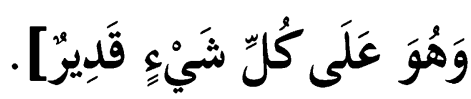

Kaum Muslimin, Jama'ah Jum'at Yang Dimuliakan Allah

Sadar atau tidak, dalam bergulirnya siang dan malam, panas terik dan dinginnya malam ada sebuah hikmah dan pesan dari Allah Subhanahu Wa Ta'ala. Di balik suara merdu burung di rindangnya 
dedaunan hutan, suara katak yang bersahutan di musim hujan, adzan mengundang kita shalat yang tak hentinya, terus berkumandang saling berkaitan dari satu tempat ke tempat lainnya di seluruh bumi, hingga sinergisnya siang dan malam bergantian sebagai tanda memuji kebesaran-Nya, dan patuh pada perintah-Nya. Sudah menjadi sunnatullah, semua makhluk di muka bumi dan di seantero langit memuji dan bertasbih pada Allah Subhanahu Wa Ta'ala.

Firman Allah Subhanahu Wa Ta'ala:

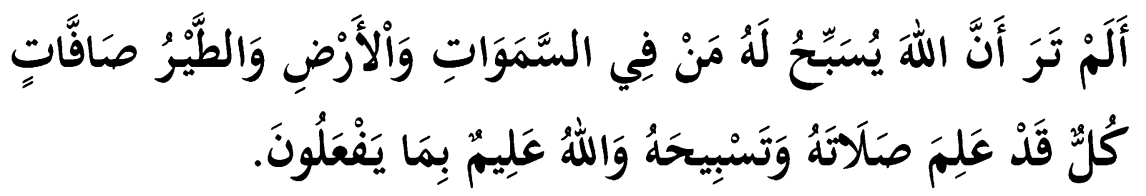

Artinya: "Tidaklah kamu tahu bahwasanya Allah: kepada-Nya bertasbih apa yang di langit dan di bumi dan burung dengan membentangkan sayapnya. Masing-masing telah mengetahui (cara) sembahyang dan tasbihnya, dan Allah Maha Mengetahui apa yang mereka kerjakan". (QS. An-Nur [24] : 41).

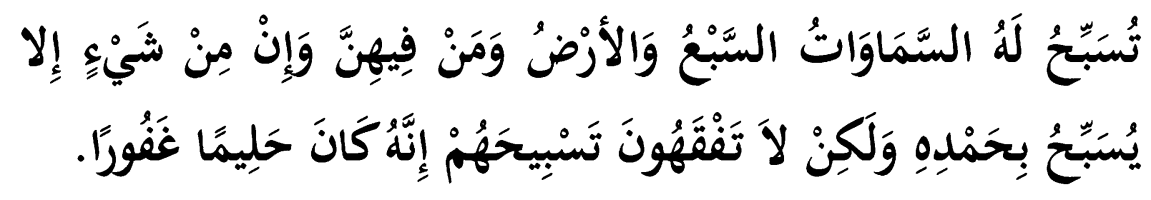

Artinya: "Langit yang tujuh, bumi dan semua yang ada di dalamnya bertasbih kepada Allah. Dan tidak ada sesuatu pun melainkan bertasbih dengan memuji-Nya, tetapi kamu tidak mengerti tasbih mereka. Sungguh, Dia Maha Penyantun lagi Maha Pengampun". (QS. Al-Isra' [17]:44).

Dalam surah Al-Anbiyaa, ayat 79, Allah menyatakan: "Dan sudah Kami tundukkan gunung-gunung dan burung-burung, semua bertasbih bersama Dawud". Bahkan hewan yang kita anggap remeh dan tak berguna pun bersepakat untuk memuji-Nya, seperti semut 
dan katak juga tak lupa berbertasbih kepada Allah Subhanahu Wa Ta'ala. Dalam hal ini, Rasulullah Shallallahu 'Alaihi Wasallam bersabda, bahwa suara katak itu tasbih, memuji Allah. (HR. Al-Nasai).

Hadist yang diriwayatkan oleh Ibn Umar: "Janganlah kamu membunuh katak karena bunyi menguaknya adalah tasbih". Demikian pula hadist dari Anas bin Malik ra.: "Janganlah kamu membunuh katak karena ia pernah melintasi di atas api Ibrahim serta membawa air di dalam mulutnya dan menyemburkannya ke atas api".

Dari benda ciptaan Allah Subhanahu Wa Ta'ala. yang kecil seperti bakteri, hingga yang sangat besar seperti makhluk matahari dan bintang-bintang yang lainnya yang lebih besar semuanya bertasbih memuji-Nya. Maha Besar Allah, Tuhan Pencipta Alam. Maka bertasbihlah kepada Allah. Gunung dan burung bertasbih dengan melaksanakan tanggungjawab mereka, supaya proses alam berjalan dengan lancar, tersusun, dan teratur. Alam pula bertasbih dengan terus mematuhi aturan yang ditetapkan oleh Allah. Diriwayatkan dari Abu Hurairah ra. berkata: "Dari Rasulullah Shallallahu 'Alaihi Wasallam: "Sesungguhnya pernah seekor semut menggigit salah seorang Nabi lalu Nabi tersebut menyuruh supaya membakar sarang semut tersebut, tetapi Allah menurunkan wahyu kepadanya": "Apakah hanya gara-gara seekor semut menggigitmu lantas kamu akan binasakan satu umat yang selalu membaca tasbih." "Akan tetapi kamu tidak faham akan tasbih mereka".

Kaum Muslimin, Jama'ah Jum’at Yang Dimuliakan Allah

Hanya Nabi Sulaiman yang diberi ilmu untuk memahami bahasa binatang. Hikmah dibalik tasbih matahari, bulan, bintang-bintang, burung, semut dan lainnya, Subhanallahu Maha Suci Allah atas keindahan penciptaannya, sebagai bukti bahwa Sang Pencipta menginginkan agar seluruh mahluk taat dan berada dalam garis edarnya sebagai manusia. Ketika matahari dan bulan taat pada garis 
edarnya sebagai bentuk ketaatan pada Allah Subhanahu Wa Ta'ala yang menciptakannya. Lalu apa yang harus kita lakukan?

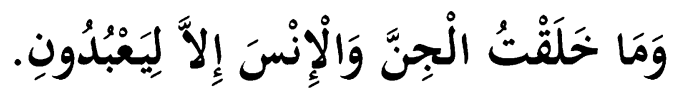

Artinya: "Tidaklah Aku menciptakan jin dan manusia melainkan agar mereka beribadah kepada-Ku". (QS. Adz-Dzariyaat [51]: 56)

Allah Subhanahu Wa Ta'ala menyampaikan teguran dalam bentuk pertanyaan sebagaman di dalam firman-Nya:

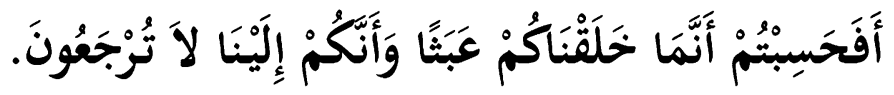

Artinya: "Maka apakah kamu mengira, bahwa sesungguhnya Kami menciptakan kamu secara main-main, dan bahwa kamu tidak akan dikembalikan kepada Kami?” (QS. Al Mukminun [23]: 115)

Imam Ibnu Katsir rahimahullah berkata, Firman Allah: "Apakah kamu mengira, bahwa sesungguhnya Kami menciptakan kamu untuk main-main?", "Apakah kalian menyangka bahwa kamu diciptakan tanpa maksud, tujuan dan hikmah?" Firman Allah: "bahwa kamu tidak akan dikembalikan kepada Kami?", "Tidak dikembalikan ke negeri akhirat?" Manusia diciptakan dengan bentuk terbaik dan dimuliakan dengan akal pikiran, karunia Allah SWT. selanjutnya menurunkan beragam rizki, sehingga manusia mampu bertahan hidup di bumi ini.

Allah berfirman:

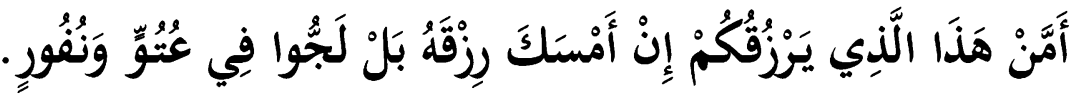

Atau siapakah dia ini yang memberi kamu rezki jika Allah menahan rezki-Nya? Sebenarnya mereka terus-menerus dalam kesombongan dan menjauhkan diri? (QS. Al-Mulk [67]: 21) 
Jika matahari, bulan, seluruh satwa, dan lainnya patuh dan tuduk kepada Allah Subhanahu Wa Ta'ala, mengapa kita abaiakan beribadah kepada Dzat yang telah mengaruniakan kepada kita segala sesuatu yang kita miliki selama ini. Semoga Allah Subhanahu Wa Ta'ala senantiasa memberi kepada kita, petunjuk dan keridhaan-Nya. Dibalik pergantian siang dan malam sangatlah luar biasa, betapa indah seluruh mahluk-Nya selain manusia terus menerus bergerak mengikuti perintah-Nya sebagai bentuk tasbih mereka kepada-Nya, sehingga terjadi keseimbangan antara kehidupan di langit dan bumi.

Demikian khutbah kali ini, semoga bermanfaat dan bisa menjadi bahan renungan bagi kita semua.

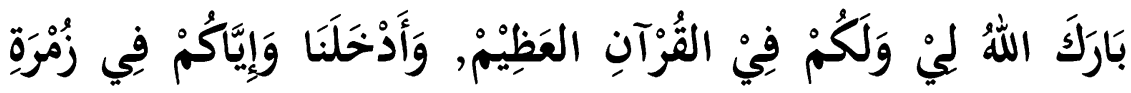

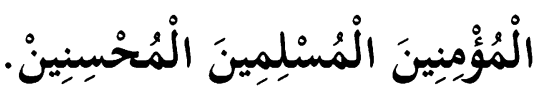




\section{Khuthbah 2}

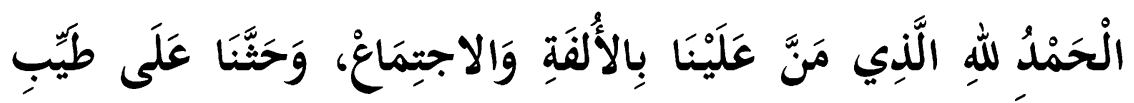

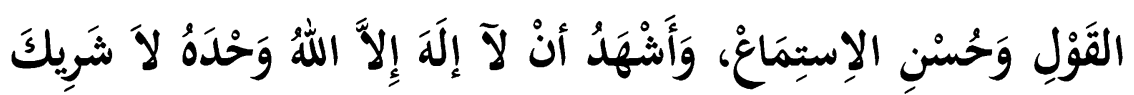

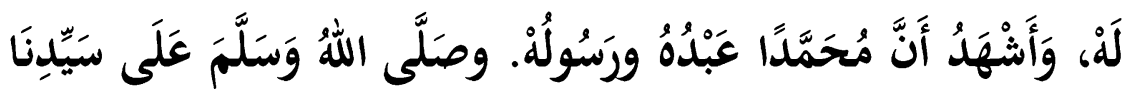

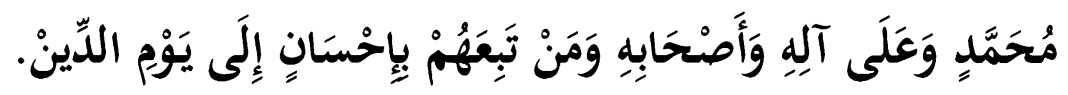

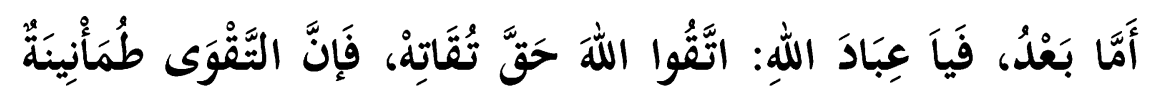

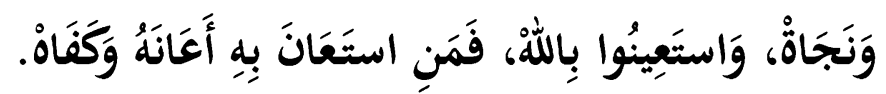

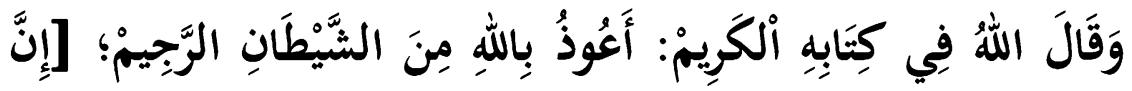

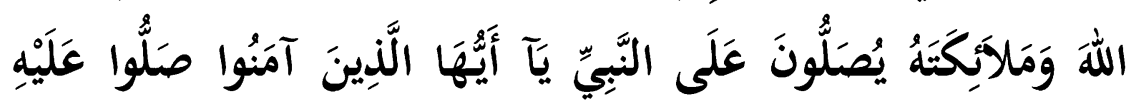

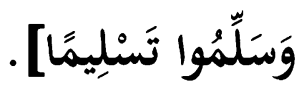

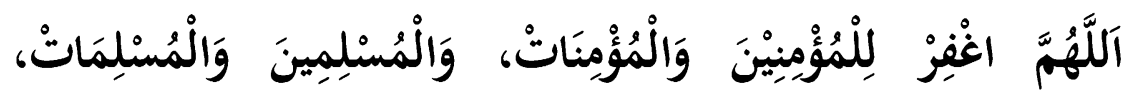

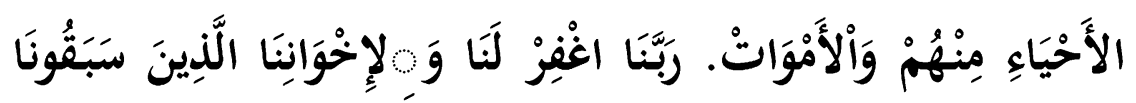

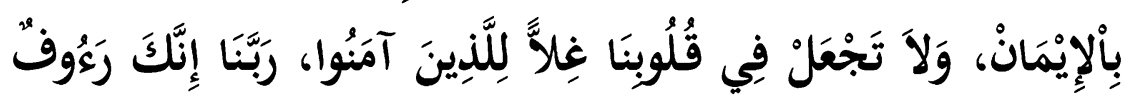

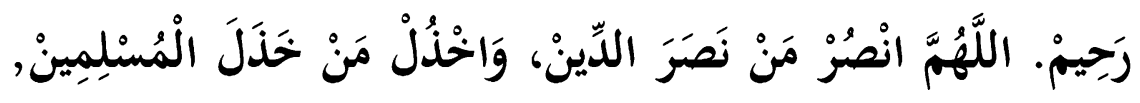

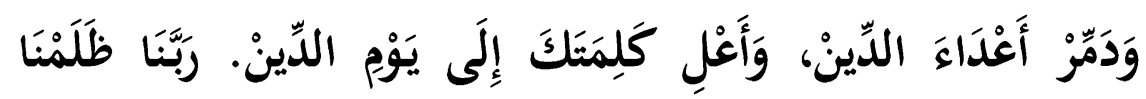




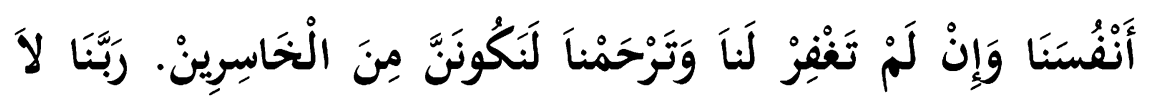

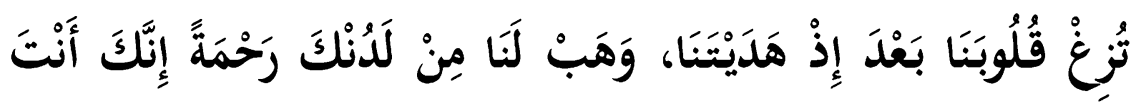

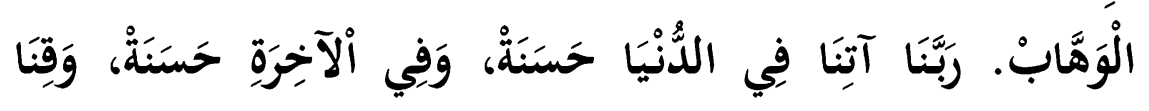

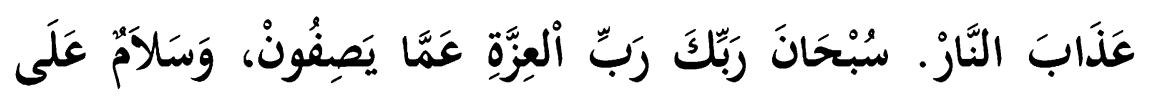

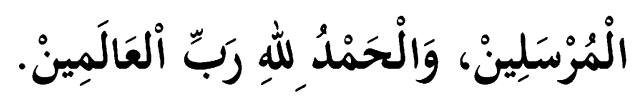

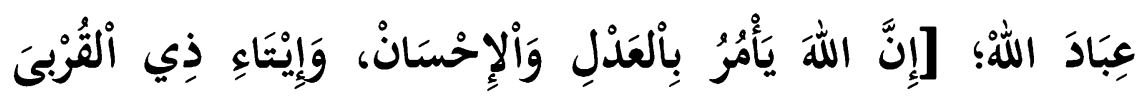

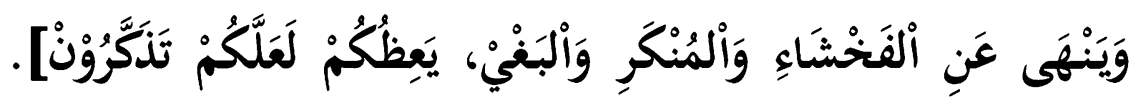

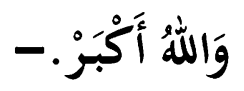




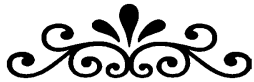 \\ PELESTARIAN ALAM DAN SATWA}

\section{Khuthbah 1}

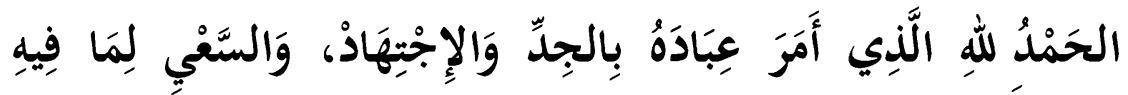

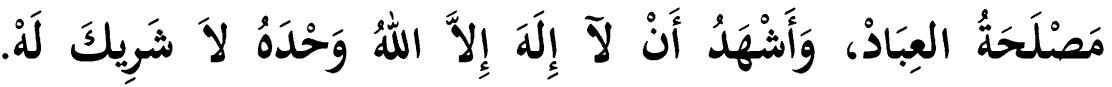

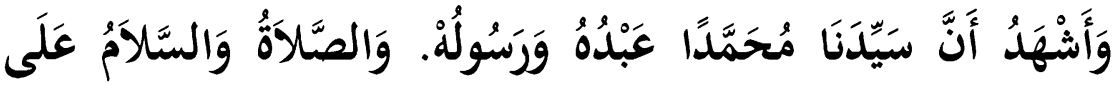

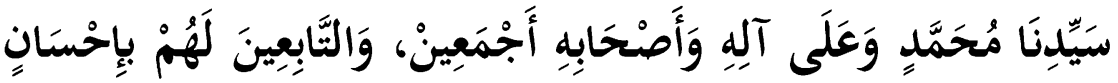

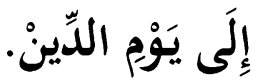

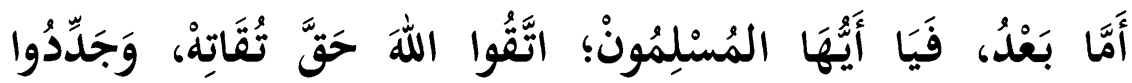
إِيْمَانَكُمْه، وَأَصْلِحُحُوا أَعْمَالَكُمْْ.

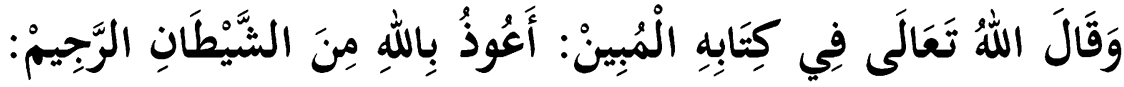

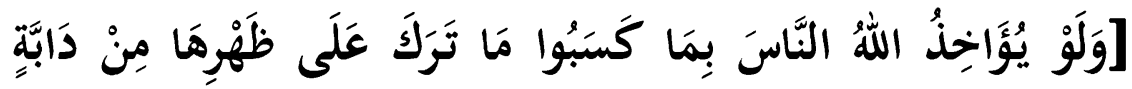

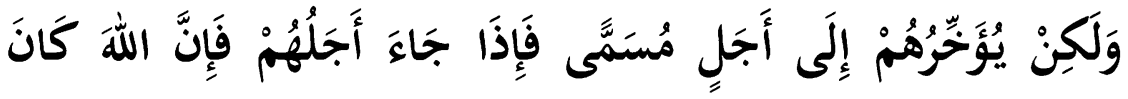

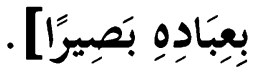

Ma’asyiral Muslimin, Sidang Jum’at Yang Berbahagia.

Kita kerap mendengar di mana-mana sekarang ini sangat sering terjadi bencana. Bahkan sifatnya menjadi rutin dan meningkat sepan- 
jang tahun. Berjenis-jenis bencana ini bertubi-tubi didominasi oleh bencana yang diakibatkan oleh ulah manusia, misalnya tanah longsor, banjir atau banjir yang diikuti oleh adanya tanah longsor.

Bencana lingkungan semakin menggejala yang diakibatkan oleh tangan-tangan manusia, sebagaimana firman Allah SWT. dalam surat Al-Rum, 41:

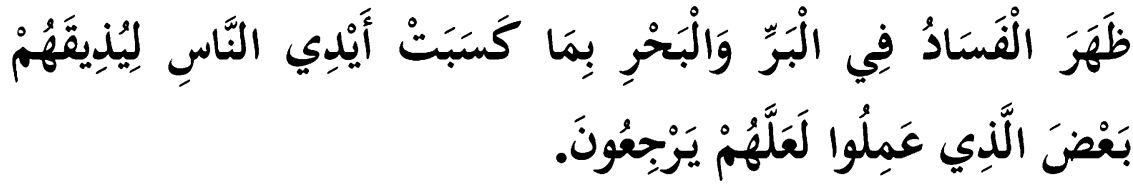

Artinya: "Telah nampak kerusakan di darat dan di laut disebabkan karena perbuatan tangan manusia, supaya Allah merasakan kepada mereka sebahagian dari (akibat) perbuatan mereka, agar mereka kembali (ke jalan yang benar)". (QS.AI-Ruum [30]: 41)

Allah menugaskan manusia sebagai khalifah di bumi untuk merawat dan menjaga bumi supaya dapat dihuni dengan baik. Allah SWT. Menurunkan Al-Qur'an untuk menjadi petunjuk dan pedoman hidup dalam memelihara dan merawat bumi untuk kemaslahatan manusia sebagai ladang badah.

Dalam ayat yang lain Allah SWT. berpesan kepada manusia, dalam surat Al Araf ayat 56:

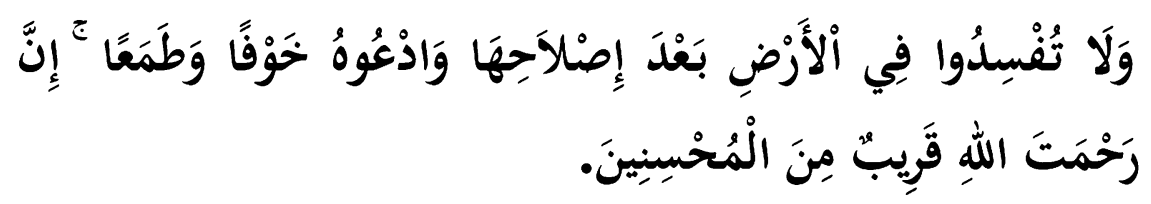

Artinya: "Dan janganlah kamu membuat kerusakan di muka bumi, sesudah (Allah) memperbaikinya dan berdo'alah kepada-Nya dengan rasa takut (tidak akan diterima) dan harapan (akan dikabulkan). Sesungguhnya rahmat Allah amat dekat kepada orang-orang yang berbuat baik". (QS. Al-Araaf [7]: 56) 
Berbagai upaya untuk menjaga dan merawat bumi telah dilakukan, terutama terkait dengan keseimbangan lingkungan. Pemerintah kita, telah menetapkan banyak sekali kawasan lindung diantaranya berupa, hutan lindung, cagar alam, taman hutan raya, suaka margasatwa dan taman nasional.

Keberadaan tersebut, memang sengaja dilakukan guna menjaga keseimbangan alam dan juga tujuan-tujuan perbaikan bagi kawasan-kawasan tersebut. Dengan adanya alam yang seimbang, maka bencana seperti banjir dan tanah longsor menjadi terhindarkan, karena hutan-hutan tersebut dapat menjalankan fungsi alamiahnya, seperti menyerap air, mencegah erosi dan menjadi pengendali keseimbangan iklim.

Nabi Muhammad SAW. memberikan beberapa warisan pengetahuan kepada kita tentang kawasan-kawasan lindung, atau yang disebut juga kawasan-kawan konservasi untuk mempertahankan keseimbangan dalam kehidupan ekosistem.

Diriwayatkan, bahwa Nabi Muhammad SAW. membuat kawasan kawasan lindung yang disebut al-hima'. Adapun pionir al-hima sesungguhnya dicontohkan oleh Nabi dengan melindungi secara khusus dua kota suci (al-haramain, Makkah dan Madinah).

Pada masa penaklukkan Mekkah, Nabi Muhammad SAW. memaklumkan tentang kesucian dua tempat itu: "Suci karena kesucian yang terapkan Allah padanya hingga hari kebangkitan. Belukar pohon-pohonnya tidak boleh ditebang, hewan-hewan tak boleh diganggu ... dan rerumputan yang baru tumbuh tidak boleh dipotong. (HR. Muslim).

Nabi SAW. membangun saluran di antara bukit-bukit untuk lava mengalir mengelilingi Madinah. Beliau bersabda: "Sesungguhnya Ibrahim memaklumkan Mekkah sebagai tempat suci dan sekarang 
aku memaklumkan Madinah, yang terletak antara dua lava mengalir, sebagai tempat suci. Pohon-pohonnya tidak boleh ditebang dan binatang-binatangnya tidak boleh diburu." Lalu Abu Hurairah bertkat: "Bila aku menemukan rusa di tempat antara dua lava mengalir, aku tidak akan mengganggunya; dan beliau [Nabi] menetapkan dua mil sekeliling Madinah sebagai kawasan terlindung [hima]." (H.R. Muslim).

Sidang Jum'at Yang Dimuliakan Allah

Hima merupakan kawasan lindung yang digagas dan diawasi langsung oleh Rasullullah SAW. Kawasan itu diakui oleh Food and Agricultural Organization (FAO) sebagai contoh pengelolaan kawasan lindung tertua di dunia, dan dan tetap bertahan sampai sekarang. Berbeda dengan kawasan lindung sekarang yang umumnya mempunyai luasan yang sangat besar dalam sejarah, hima memiliki ukuran luas yang berbeda-beda, dari beberapa hektar sampai ratusan kilometer persegi. Hima al-Rabadha yang dibangun oleh Khalifah Umar ibn Khatthab ra. dan diperluas oleh Khalifah Usman ibn Affan, adalah salah satu yang terbesar, membentang dari tempat ar-Rabadhah di barat Najd sampai ke dekat kampung Dariyah. Di antara hima tradisional adalah lahan-lahan penggembalaan yang paling baik dikelola di semenanjung Arabia; beberapa di antaranya telah dimanfaatkan secara benar untuk menggembala ternak sejak masa-masa awal Islam dan merupakan contoh pelestarian kawasan penggembalaan yang paling lama bertahan yang pernah dikenal.

Pada tahun 1965 diperkirakan terdapat sekitar 3000 hima di Saudi Arabia, mencakup sebuah kawasan luas di bawah pengelolaan konservasionis dan berkelanjutan. Hampir setiap desa di barat laut pegunungan itu termasuk ke dalam salah satu atau lebih hima, yang terkait juga dengan sebuah perkampungan sebelahnya. Hima-hima itu bervariasi dari 10 sampai 1000 hektar dan rata-rata berukuran sekitar 250 hektar. 
Dengan demikian menjadi jelas bahwa, Nabi SAW. memberikan teladan teladan dalam menggagas dan memprakarsai terciptanya kawasan-kawasan konservasi untuk menangkal terjadinya bencana alam demi kemaslahatan bagi kehidupan manusia dan makhluk lain terutama satwa.

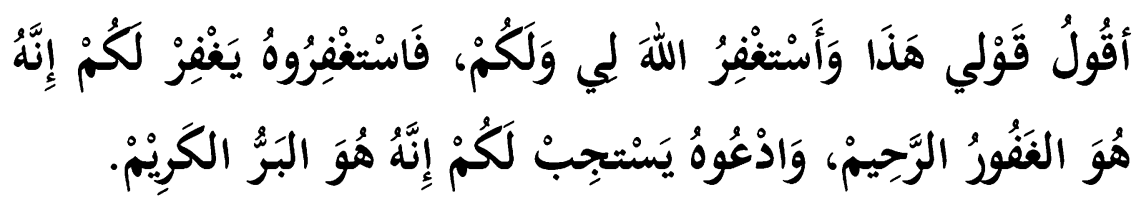




\section{Khuthbah 2}

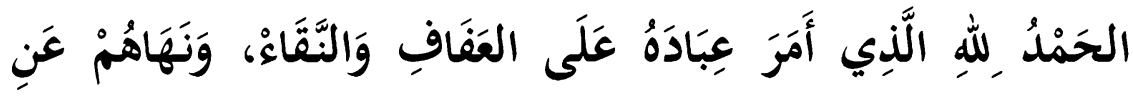

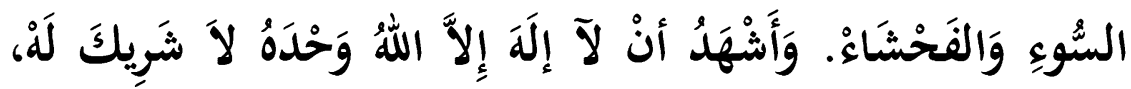

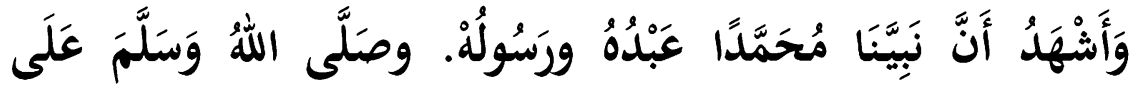

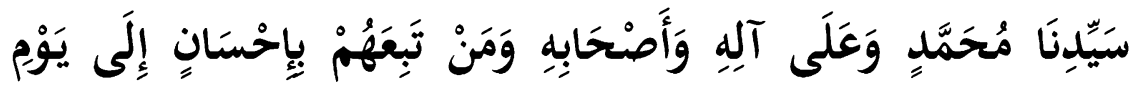
الدِّين.

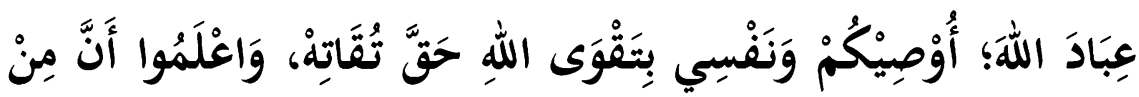

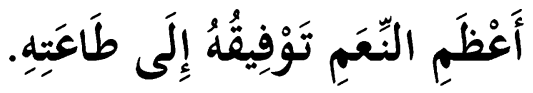

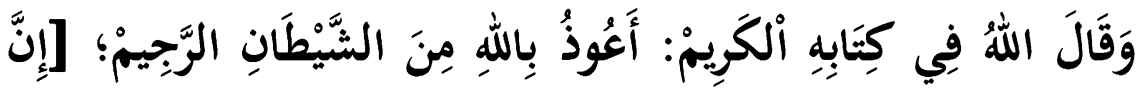

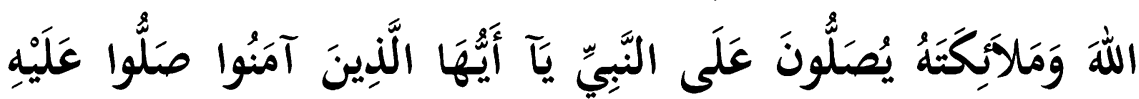

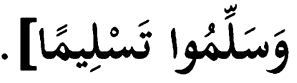

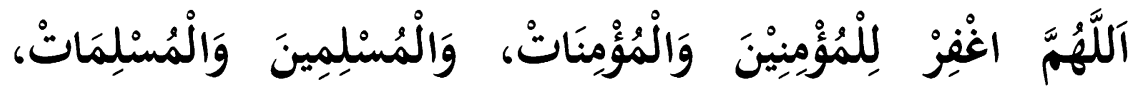

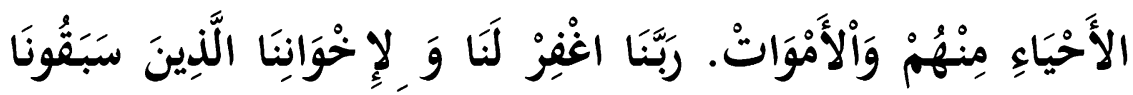

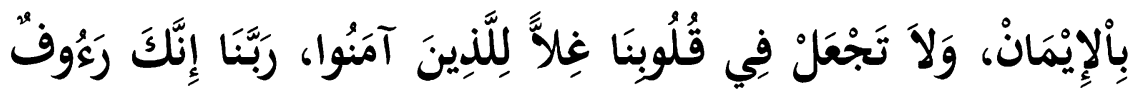




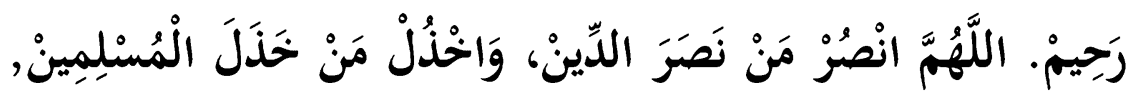

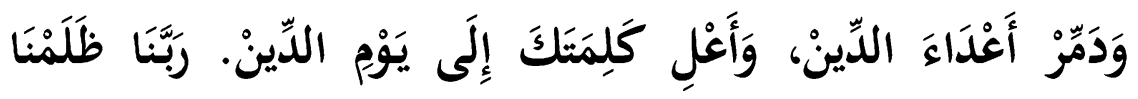

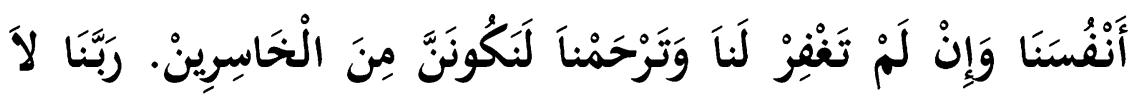

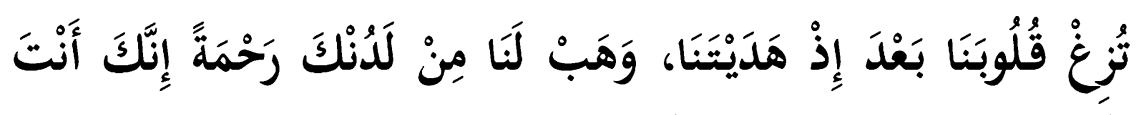

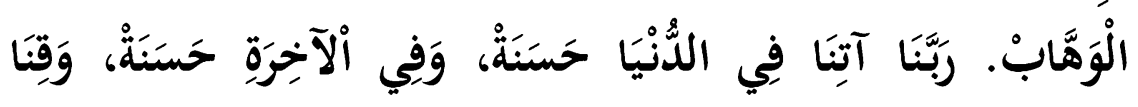

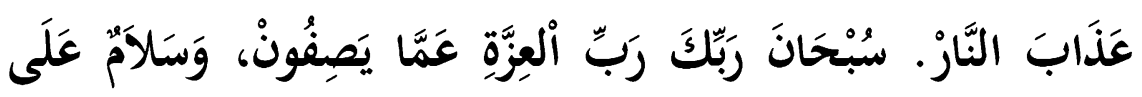

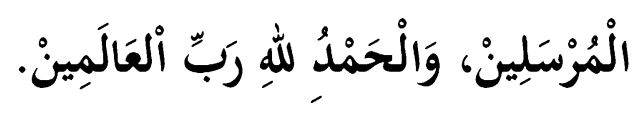




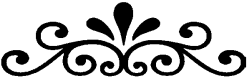 \\ MENGAPA ALLAH MENCIPTAKAN \\ MAKHLUK SELAIN MANUSIA}

\section{Khuthbah 1}

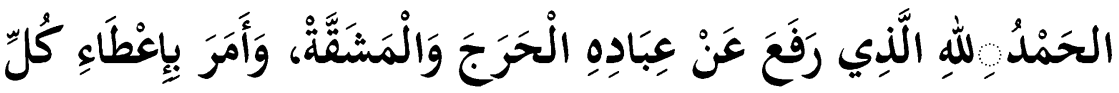

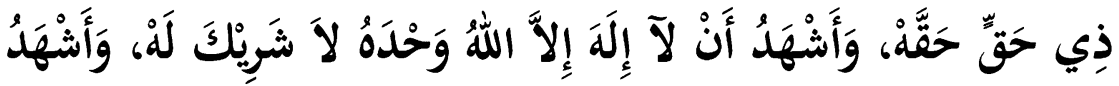

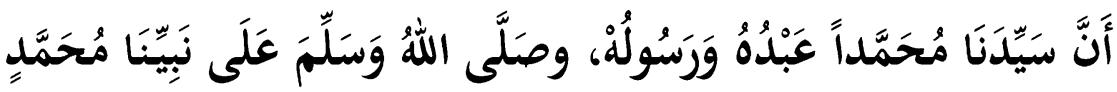

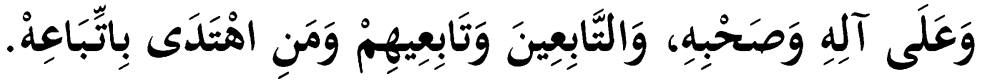

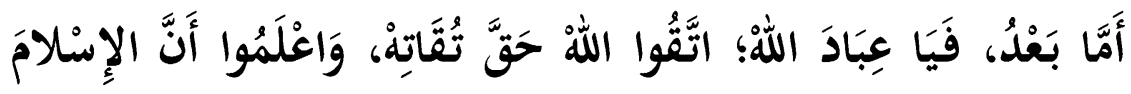

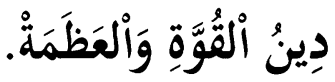

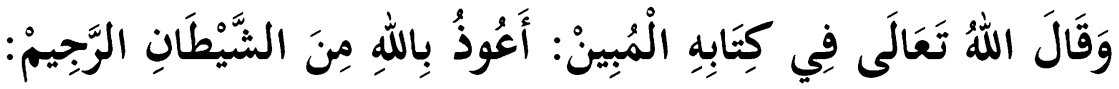

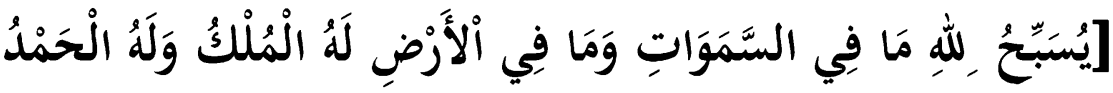

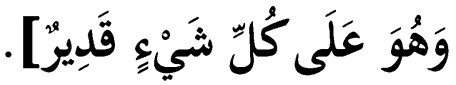

Kaum muslimin sidang jumat yang dirahmati Allah

Tujuan diciptakannya manusia dan jin adalah untuk beribadah kepada Allah SWT. hal tersebut termaktub di dalam firman Allah surat Adz-Dzariyat ayat 56:

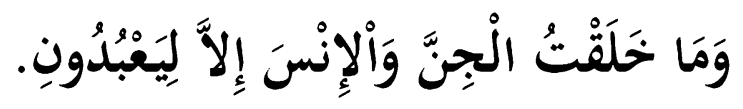


Artinya: "Dan Aku (Allah) tidak menciptakan manusia dan jin kecuali untuk beribadah (kepada Ku)". (QS. Adz-Dzariyat [51]: 56).

Jin dan manusia dijadikan oleh Allah SWT. untuk beribadah kepada-Nya. Tegasnya, Allah menjadikan kedua makhluk itu sebagai makhluk-makhluk yang mau beribadah, diberi akal dan panca indera yang mendorong mereka menyembah Allah, untuk beribadahlah tujuan mereka diciptakan. Dengan demikian, ibadah yang dimaksud di sini lebih luas jangkauannya daripada ibadah dalam bentuk ritual. Setiap perbuatan yang kita niatkan untuk Allah SWT, insyaAllah itu akan dicatat oleh-Nya sebagai amal ibadah kita.

Allah SWT. mengangkat manusia untuk menjadi khalifah di muka bumi ini. Yang dimaksud khalifah ialah penguasa yang mengatur segala sesuatu yang ada di bumi, seperti satwa, tumbuhan, hutan, gunung, air, sungai, laut, ikan. Seyogyanya manusia harus mampu memanfaatkan segala apa yang ada di bumi untuk kemaslahatannya. Jika manusia telah mampu melaksanakannya, maka sunatullah yang menjadikan manusia sebagai khalifah di bumi benar-benar dilaksanakan dengan baik oleh manusia, terutama mereka yang beriman kepada Allah SWT. dan Rasulullah SAW.

Manusia selain sebagai khalifah di muka bumi, juga sebagai hamba Allah SWT. yang diperintah untuk menyembah-Nya. Dalam hal ini, perintah menyembah Allah karena sesungguhnya Allah yang menciptakan semua alam semesta ini.

Selain menciptakan manusia dan jin, Allah SWT. juga menciptakan makhluk lainnya seperti satwa, tumbuhan, daratan, lautan, langit, bintang, matahari, bulan, planet-planet dan benda angkasa lainnya, dan lain sebagainya. Lalu, untuk apakah semua itu diciptakan?

Ma'asyiral muslimin yang berbahagia 
Seluruh ciptaan Allah SWT di langit dan bumi tidaklah sia-sia. Dia ciptakan selain manusia, makhluk-makhluk yang membawa manfaat bagi kehidupan manusia. Setidaknya ada tiga alasan mengapa diciptakan makhluk-makhluk selain manusia.

Pertama, sebagai bahan renungan bagi umat manusia akan keagungan dan kebesaran Allah SWT. Manusia itu hanya seonggok daging yang hidup di hamparan alam jagat raya ini. Hal tersebut sesuai dengan firman Allah dalam surat Ali Imran ayat 190-191:

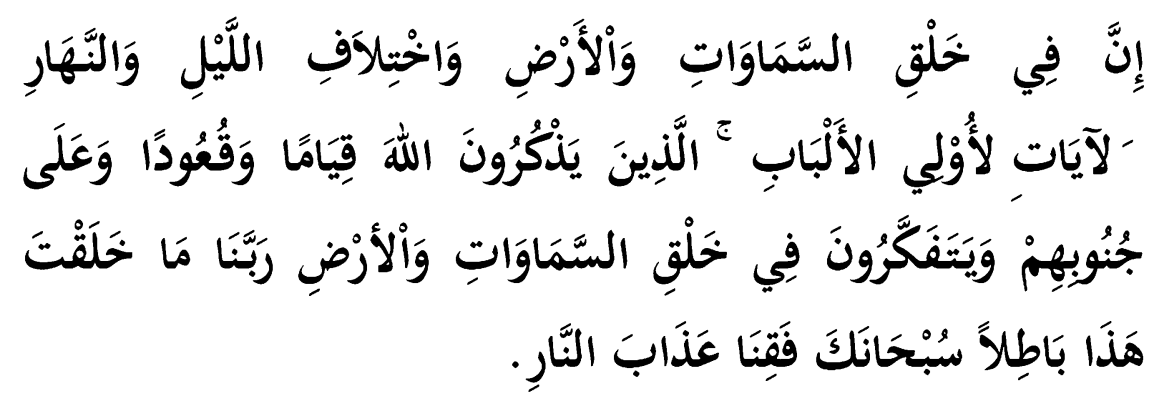

Artinya: "Sesungguhnya dalam penciptaan langit dan bumi, dan pergantian malam dan siang, terdapat tanda-tanda (kebesaran Allah) bagi orang-orang yang berakal. (yaitu) Orang-orang yang mengingat Allah sambil berdiri atau duduk atau dalam keadan berbaring dan mereka memikirkan tentang penciptaan langit dan bumi (seraya berkata): "Ya Tuhan kami, Tiadalah Engkau menciptakan ini dengan sia-sia, Maha suci Engkau, Maka peliharalah kami dari siksa neraka". (QS. Ali Imran [3]: 190-191)

At-Thabari dan Ibnu Abi Hatim meriwayatkan dari Ibnu Abbas ra., bahwa orang-orang Quraisy mendatangi kaum Yahudi dan bertanya tentang kebenaran apakah yang dibawa oleh Musa kepada mereka. Mereka menjawab bahwa tongkatnya dan tangannya yang putih bersinar bagi yang memandangnya. Kemudian orang-orang Quraisy mendatangi kaum Nasrani dan menanyakan, kebenaran yang dibawa oleh Isa. Kemudian dijawab lah bahwa Isa menyembuhkan mata 
yang buta sejak lahir dan penyakit sopak serta menghidupkan orang yang sudah mati. Selanjutnya orang-orang Quraisy tersebut mendatangi Rasulullah SAW. dan berkata, "Mintalah dari Tuhanmu agar bukit safa itu jadi emas untuk kami". Kemudian Nabi SAW. berdoa, dan lalu turunlah ayat tersebut. Nabi mengajak mereka untuk merenungkan kejadian langit dan bumi, dan hal-hal yang menakjubkan di dalamnya, seperti bintang-bintang, bulan dan matahari serta peredaran keduanya, laut, gunung-gunung, pohon-pohon, buah-buahan, dan sebagainya.

Kedua, makhluk-makhluk tersebut juga tunduk dan bertasbih kepada Allah SWT. sebagaimana di dalam surat An-Nur, ayat 41:

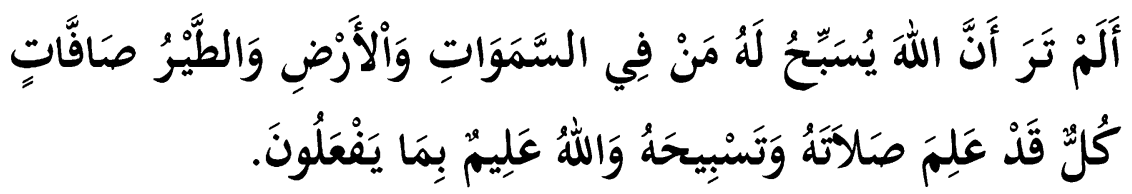

Artinya: "Tidaklah kamu tahu bahwasanya Allah: kepada-Nya bertasbih apa yang di langit dan di bumi dan (juga) burung dengan mengembangkan sayapnya. Masing-masing telah mengetahui (cara) sembahyang dan tasbihnya, dan Allah Maha Mengetahui apa yang mereka kerjakan". (QS. An-Nur [24] : 41)

Matahari, bintang, bulan dan seluruh makhluk yang ada di langit dan bumi bertasbih dan patuh kepada Allah. Bertasbih bagi makhluk selain manusia bukanlah sebagaimana kita bertasbih dan berzikir dengan menyebut nama Allah, tetapi mereka memiliki cara-cara tertentu yang tak dapat kita ketahui. Hanya Allah SWT. Yang Maha Mengetahui bagaimana cara mereka bertasbih. Masing-masing dari makhluk tersebut telah mendapatkan bimbingan dari Allah tentang cara bertasbih.

Pada suatu ketika Nabi Muhammad SAW. pernah mendengar batu kerikil di bawah telapak kakinya bertasbih kepada Allah. Pernah pula 
ketika Nabi Daud meniup serulingnya, Allah memerintahkan kepada gunung-gunung dan burung-burung supaya bertasbih bersama Nabi Daud menyucikan nama-Nya sebagaimana di dalam Al Quran:

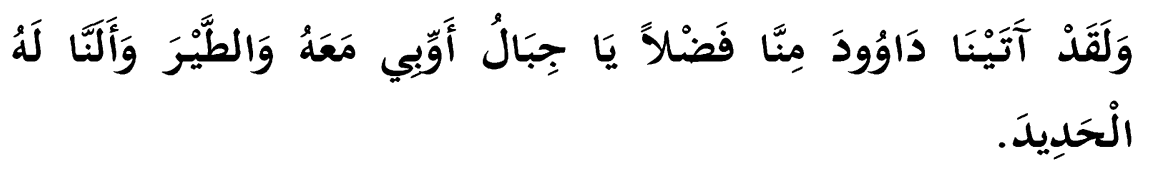

Artinya: "Dan sesungguhnya telah Kami berikan kepada Daud karunia dari Kami (Kami berfirman), "Hai gunung-gunung dan burung-burung bertasbihlah, berulang-ulang bersama Daud", dan Kami telah melunakkan besi untuknya". (Q.S. Saba [34] : 10).

Ketiga, sebagai nikmat untuk manusia sebagaimana firman Allah SWT:

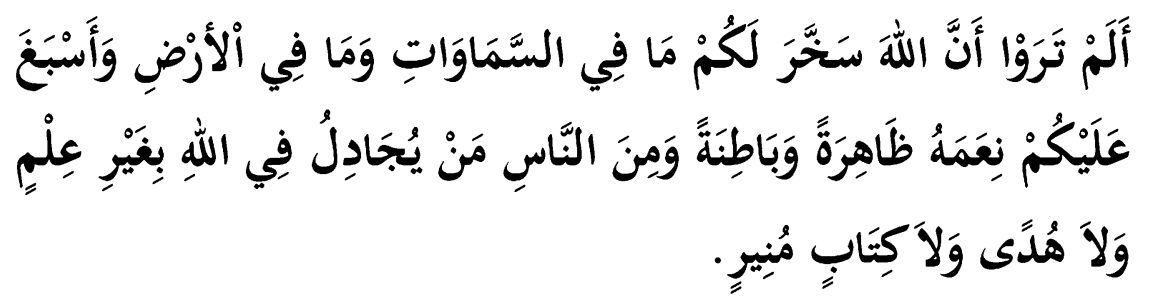

Artinya: "Tidakkah kamu perhatikan sesungguhnya Allah telah menundukkan untuk (kepentingan) mu apa yang di langit dan apa yang di bumi dan menyempurnakan untukmu nikmat-Nya lahir dan batin. Dan di antara manusia ada yang membantah tentang (keesaan) Allah tanpa ilmu pengetahuan atau petunjuk dan tanpa Kitab yang memberi penerangan". (QS. Luqman [31] : 20).

Allah SWT. menciptakan dan menundukan segala sesuatu yang ada di langit dan bumi, lalu manusia diilhami pengetahuan untuk dapat memanfaatkannya sesuai kebutuhan mereka. Sungguh, Allah tidak menciptakan semua itu sia-sia sebagaimana firman Allah SWT.: 


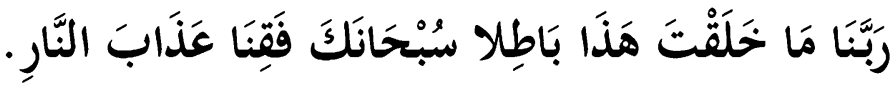

Artinya: "Ya Tuhan Kami, Tiadalah Engkau menciptakan ini dengan sia-sia, Maha suci Engkau, Maka peliharalah Kami dari siksa nera$k a^{\prime \prime}$ (QS. An-NahI[16]: 191).

Demikian khutbah kali ini, semoga bermanfaat dan bisa menjadi bahan renungan bagi kita semua.

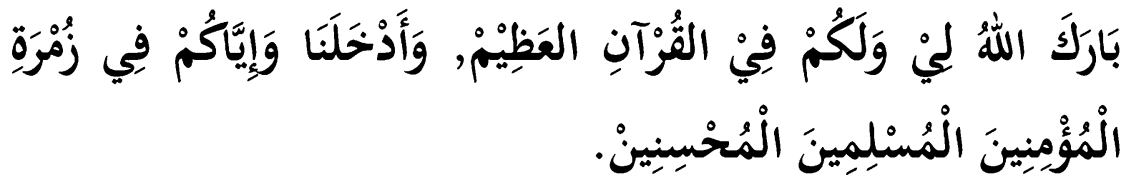




\section{Khuthbah 2}

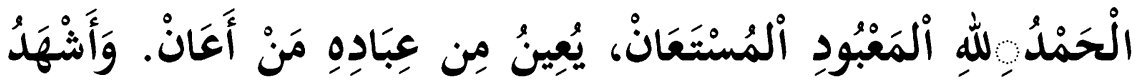

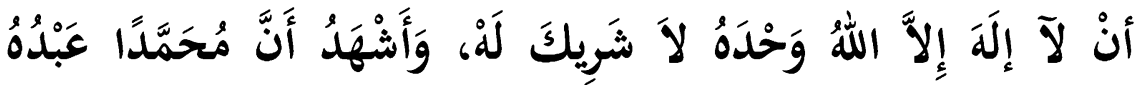

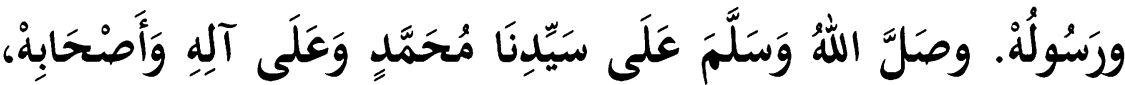

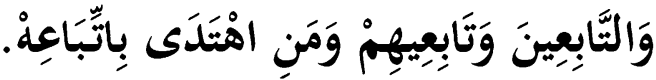

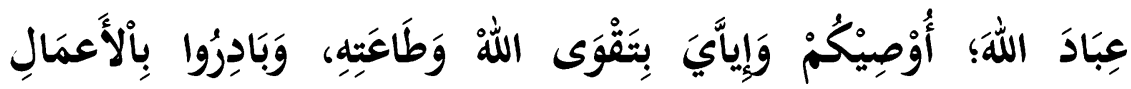

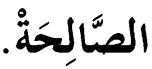

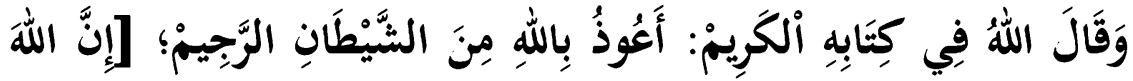

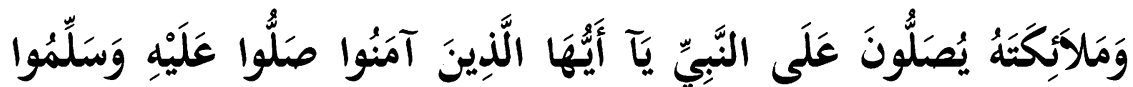

تَسْلِيمًا [.

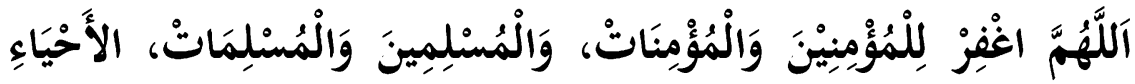

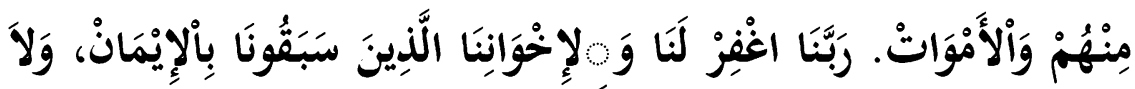

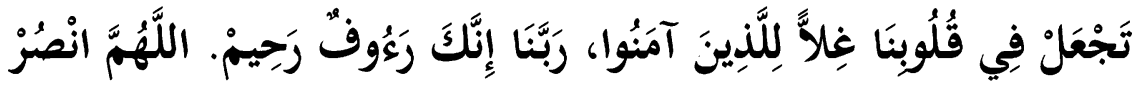

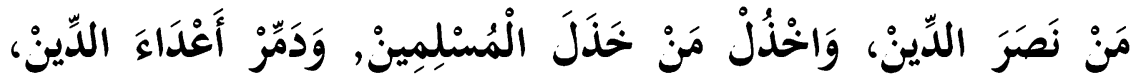

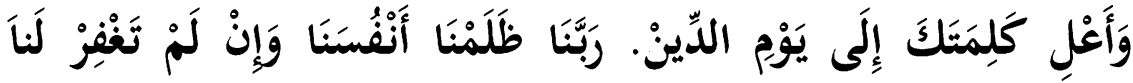




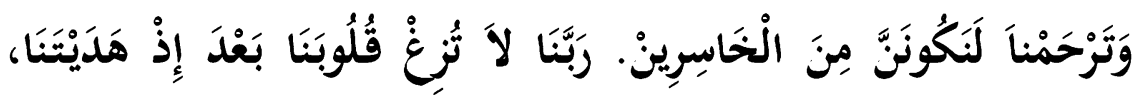

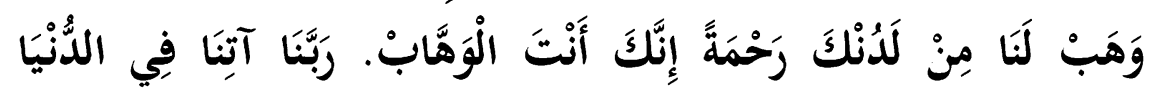

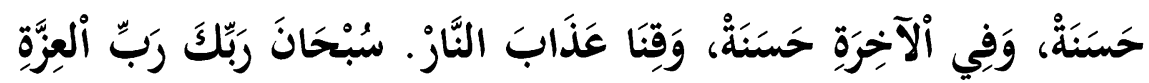

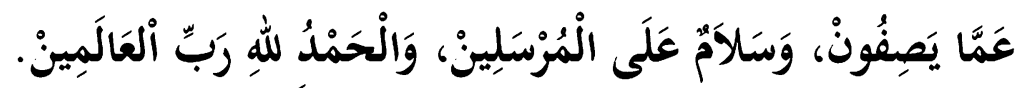

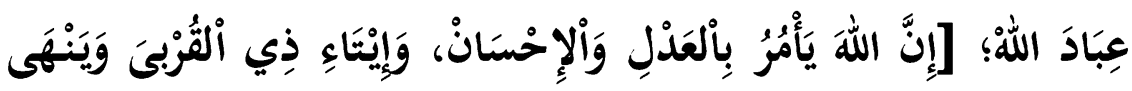

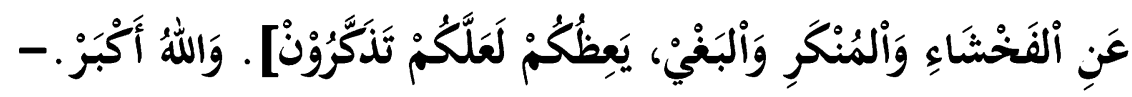




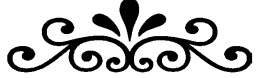 \\ MENSYUKURI DAN MERAWAT ALAM TERMASUK SATWA}

\section{Khuthbah 1}

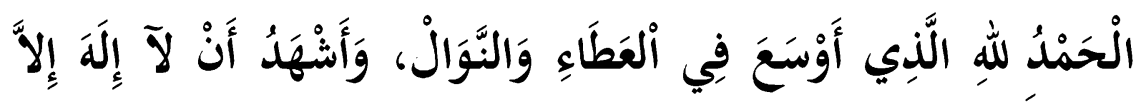

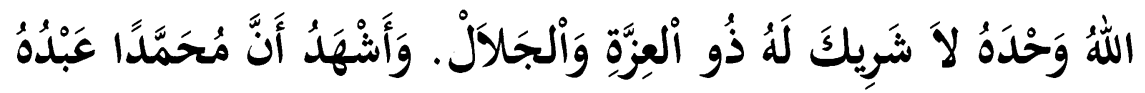

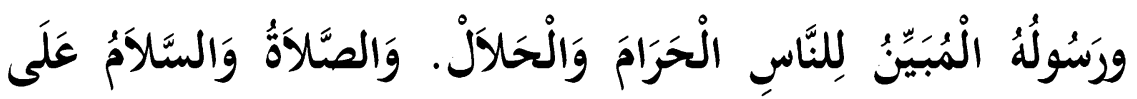

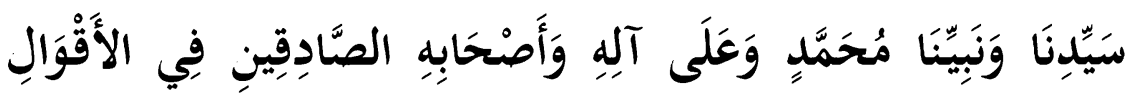

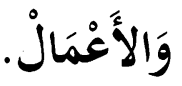

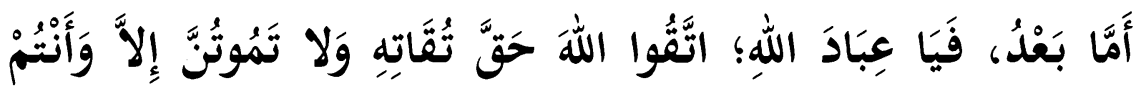

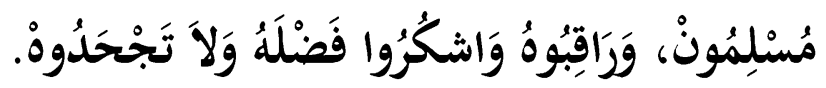

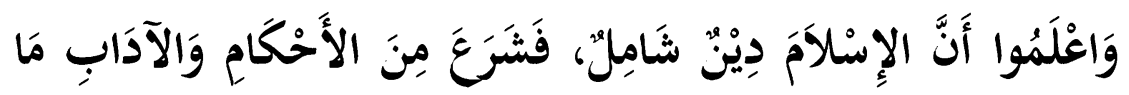

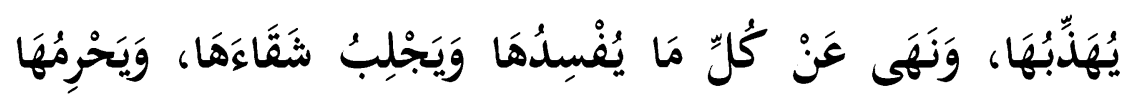

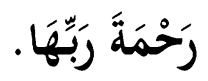

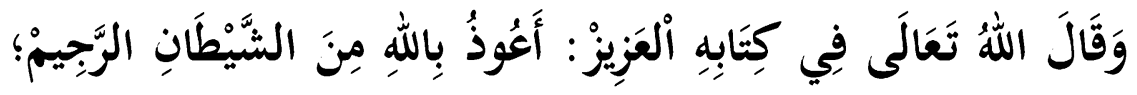

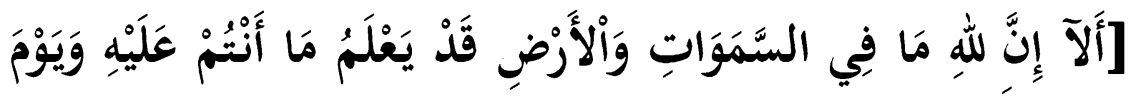

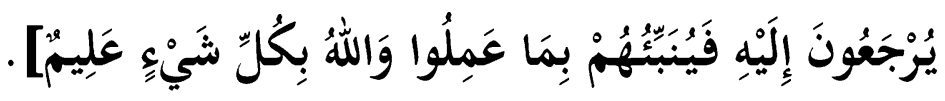


Tanah air kita Indonesia terdiri dari ribuan pulau, ada sekitar 17.504 pulau dan ditakdirkan Allah berada di sekitar garis katulistiwa yang memberikan cuaca wajar. Luas daratan Indonesia sekitar 1.919.440 $\mathrm{km}^{2}$, luas lautannya adalah $3.257 .357 \mathrm{~km}^{2}$, dan luas keseluruhan Indonesia adalah seluas $5.176 .797 \mathrm{~km}^{2}$. Disamping luas dan letak yang cukup strategis itu, Indonesia juga memiliki potensi sumber daya alam, termasuk plasma nutfah yang melimpah, biodiversity darat Indonesia merupakan terbesar nomor dua di dunia, setelah Brasil - sedangkan bila termasuk biodiversity laut maka Indonesia merupakan terbesar di dunia. Adapun kekayaan hutan kita, tidak hanya jenis tanaman, 515 jenis mamalia, 511 jenis reptil, 1.531 jenis burung dan banyak lagi yang tidak terdapat di wilayah atau negara lain.

Sebagai negeri kepulauan yang memiliki garis pantai sepanjang $81.000 \mathrm{~km}^{2}$ atau sekitar $14 \%$ garis pantai dunia, maka laut Indonesia kaya akan sumber daya alam meliputi hutan mangrove, terumbu karang, ikan hias, rumput laut dan perikanan. Sedangkan perikanan laut Indonesia juga kaya akan jenis-jenis ikan yang bersifat ekonomis seperti tongkol, cakalang, relagit kecil, kerang dan udang. Namun pada kenyataan karunia llahi berupa negeri subur yang memperoleh kekayaan yang luar biasa ini masih belum dimanfaatkan dengan baik untuk kepentingan masyarakat dan rakyat kita. Ini ditandai adanya kerusakan lingkungan hidup masih terjadi. Termasuk pembakaran dan penebangan hutan yang merajalela juga eksploitasi pertambangan, baik hutan dan laut yang semena-mena.

Ini semua merupakan adanya gangguan dan kerusakan pada berbagai ekosistem yang menyebabkan komponen-komponen yang menyusun ekosistem, yaitu keanekaragaman varietasi (sub species diversity) keanekaragaman jenis (species diversity) juga ikut terganggu. 
Firman Allah SWT.:
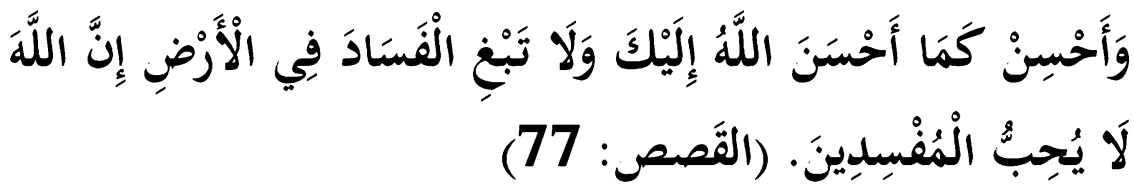

Artinya: "Dan berbuat baiklah (kepada orang lain) sebagaimana Allah telah berbuat baik kepadamu, dan janganlah kamu berbuat kerusakan di (muka) bumi. Sesungguhnya Allah tidak menyukai orang-orang yang berbuat kerusakan".

Sidang Jum'at Yang Dirahmati Allah

Sebagaimana kita ketahui, bahwa sejak tahun 1970 sudah mulai marak adanya penggundulan hutan, dan laju kerusakan hutan diperkirakan mencapai 2,8 juta hektar pertahun, kerusakan hutan di tanah air kita ini disebabkan beberapa faktor antara lain :

a. penebangan liar (illegal logging)

b. kebakaran hutan dan lahan

c. kerusakan pertambangan

d. perubahan fungsi hutan (konservasi) menjadi perkebunan, hutan menjadi hutan industri dan hutan wisata

e. penebangan yang tidak lestari (selain illegal logging)

f. industri pengolahan kayu saat ini membutuhkan sekitar 80 juta meter kubik kayu untuk memenuhi kebutuhan kayu lapis, kertas, pengergajian dll.

Untuk jangka panjang, hal ini sangat membahayakan keberlanjutan dan keseimbangan ekosistem. Disamping itu, rusak dan hilangnya hutan juga akan dirasakan secara langsung terganggu kelestarian sumber ekonomi dan budaya masyarakat desa dan yang berdekatan dengan hutan dan juga terancamnya kehidupan satwa langka seperti banteng, badak, harimau, gajah dll. Padahal dalam kehidupan ini diperlukan adanya keseimbangan kehidupan yang baik dan harmo- 
nis antara manusia dengan Allah SWT yang menciptakan, dan antara manusia dengan sesama manusia dan mkhluk lainnya. Seperti air, tumbuh-tumbuhan, binatang dan lingkungan sekitar.

Manusia sebagai makhluk Allah SWT. yang memiliki kelebihan dari makhluk yang lain, memiliki tanggung jawab untuk memelihara dan menjaga keseimbangan alam tersebut.

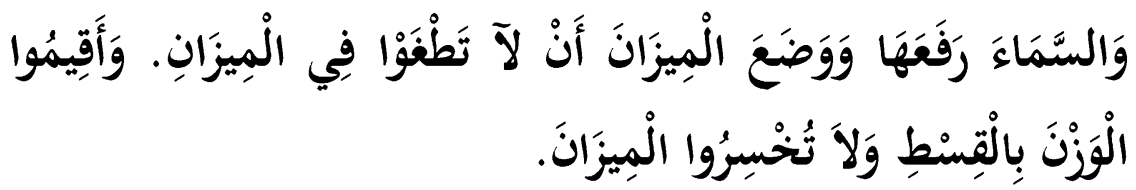

Artinya: "Allah telah meninggikan langit dan Dia meletakkan neraca (keadilan). supaya kamu jangan melampaui batas tentang neraca itu. Dan tegakkanlah timbangan itu dengan adil dan janganlah kamu mengurangi neraca itu. (Q.S Ar-Rahman [55]: 7-9)

Sidang Jum'at Yang Dirahmati Allah

Ada dua hal yang perlu disyukuri oleh bangsa Indonesia. Pertama, kita bersyukur kepada Allah SWT yang telah memberikan atau mengkaruniai kita tanah air Indonesia yang indah permai dan subur makmur serta kekayaan alam yang melimpah. Kedua, kita bersyukur karena Allah SWT yang telah memberikan kemerdekaan kepada bangsa Indonesia pada tanggal 17 Agustus 1945 yang menjadi sebuah negara Republik Indonesia yang bersatu dan berdaulat. Oleh sebab itu sebagai negara dan sebagai bangsa yang hendaknya kita merawat dan memelihara kedua anugerah yang dikaruniakan Allah kepada kita.

Semoga kita termasuk orang-orang yang pandai bersyukur atas nikmat sekarang dan yang akan datang. 


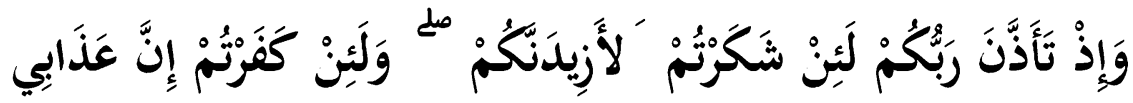 كَثَدِيدُ.}

Artinya: "dan (ingatlah juga), tatkala Tuhanmu memaklumkan: "Sesungguhnya jika kamu bersyukur, pasti Kami akan menambah (nikmat) kepadamu, dan jika kamu mengingkari (nikmat-Ku), maka sesungguhnya azab-Ku sangat pedih". (QS. Ibrahim [14]: 7).

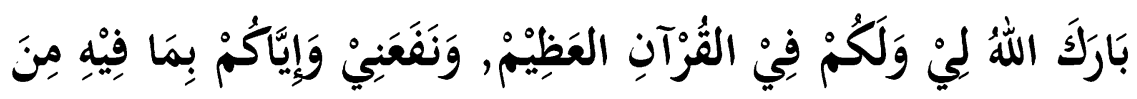

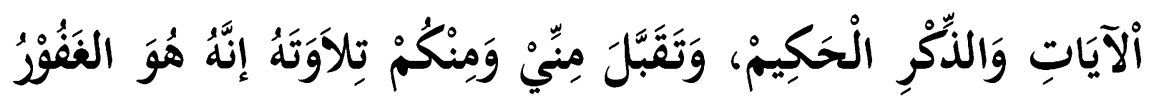

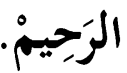




\section{Khuthbah 2}

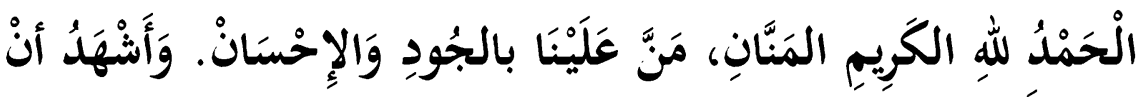

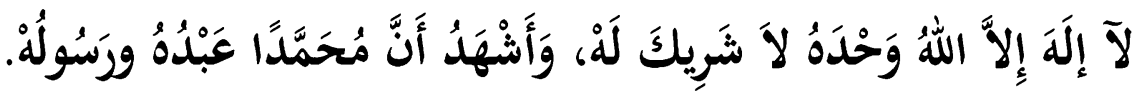

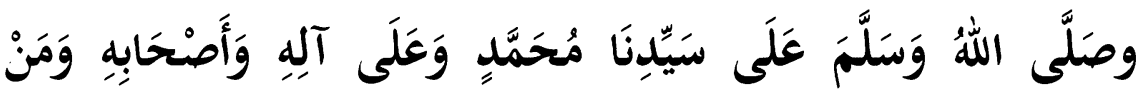

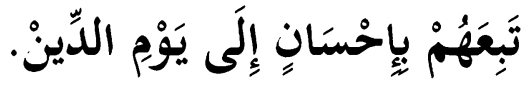

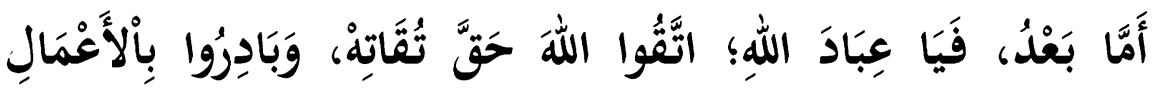

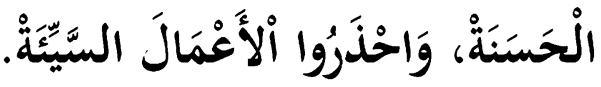

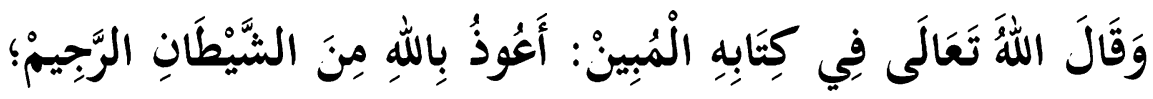

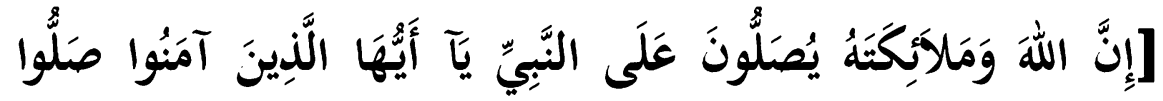

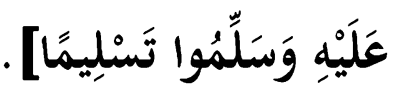

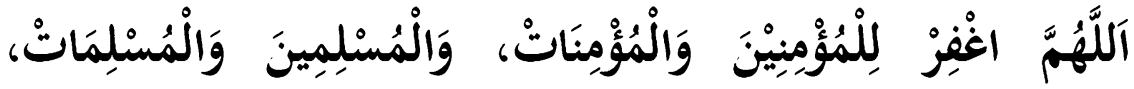

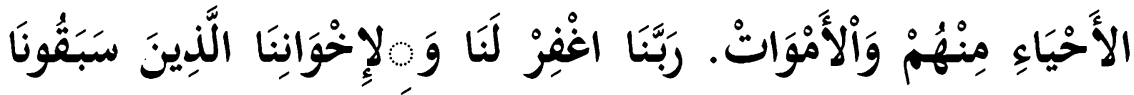

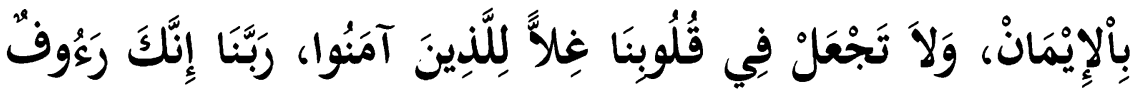

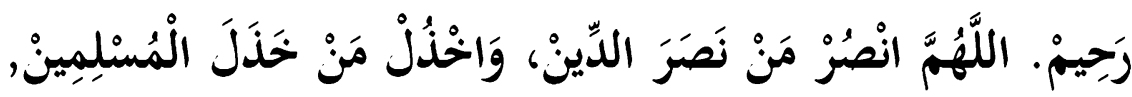

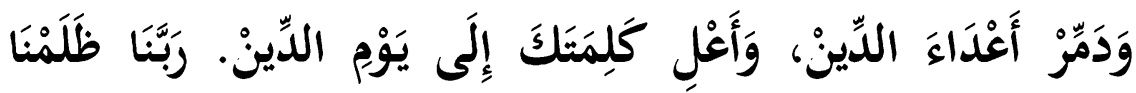




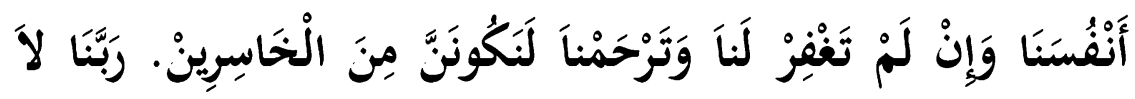

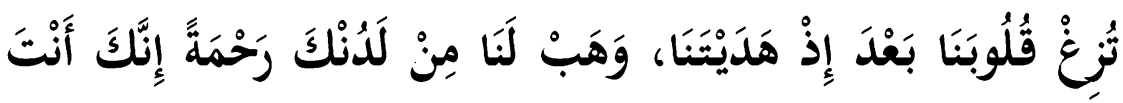

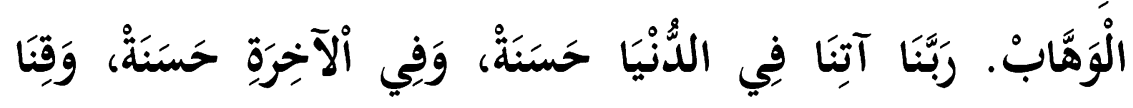

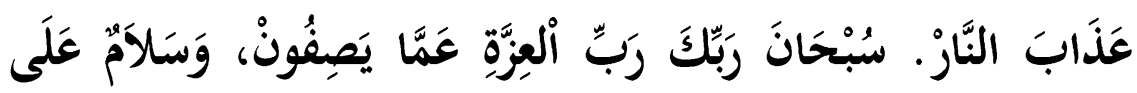

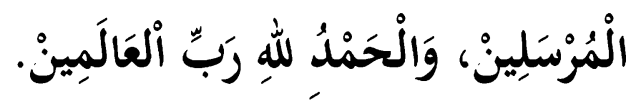

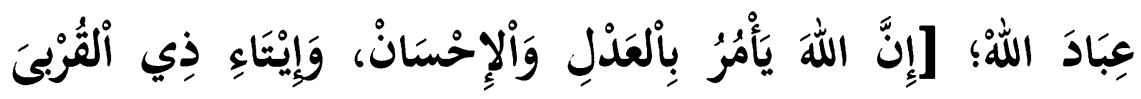

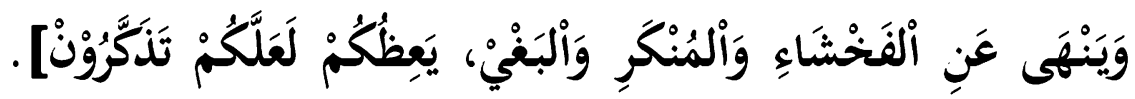

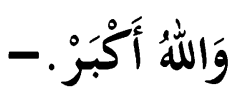




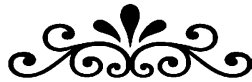 \\ AKHLAK MEMANFAATKAN \\ SUMBER DAYA ALAM \\ TERMASUK SATWA}

\section{Khuthbah 1}

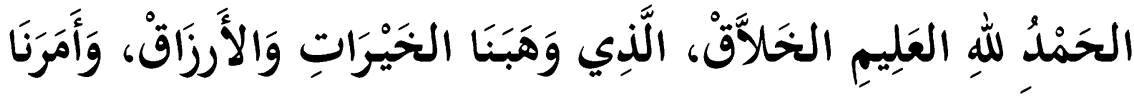

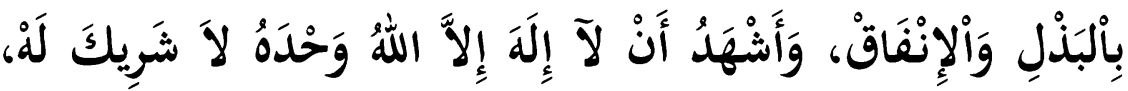

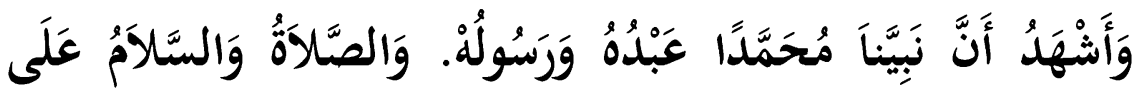

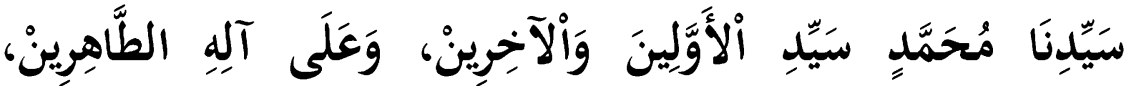

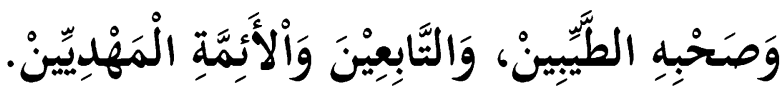

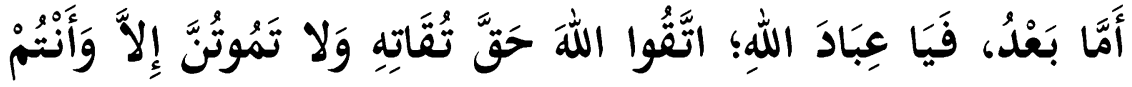

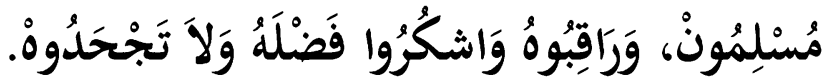

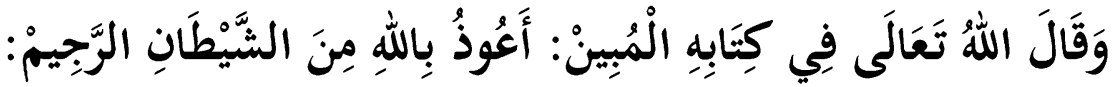

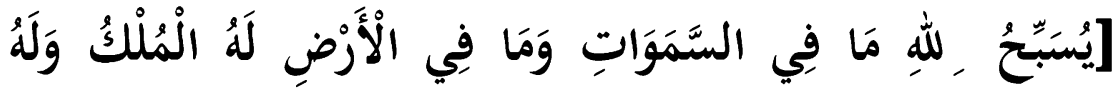

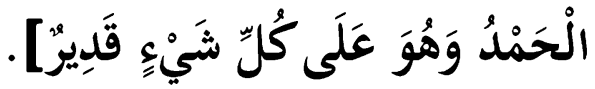


Kaum Muslimin Sidang Jum'at, Rahimakumullah

Indonesia dikenal dengan kekayan sumber daya alam yang berlimpah; air, minyak, gas dan tanah yang subur. Semua itu membuat Indonesia menjadi negara kaya dari sumber daya alamnya. Sumber daya alam yang berlimpah ini Allah SWT. ciptakan semuanya untuk manusia, sebagaimana Allah SWT. berfirman dalan surat An-Nahl, Ayat 14:

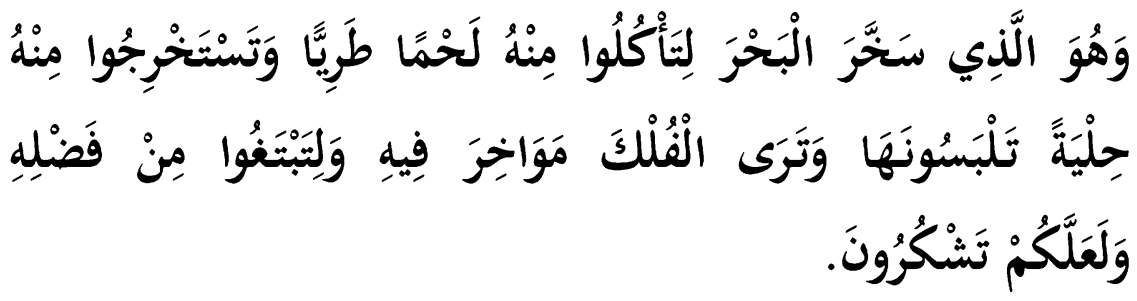

Artinya: "Dia-lah, Allah yang menundukkan lautan (untukmu), agar kamu dapat memakan daripadanya daging yang segar (ikan), dan kamu mengeluarkan dari lautan itu perhiasan yang kamu pakai; dan kamu melihat bahtera berlayar padanya, dan supaya kamu mencari (keuntungan) dari karunia-Nya, dan supaya kamu bersyukur". (QS. An-Nahl [16]: 14).

Sumber daya alam seperti air, udara, lahan, energi, satwa, hutan, dan lain-lain merupakan sumber daya yang esensial bagi kelangsungan hidup manusia. Hilangnya atau berkurangnya ketersedian sumber daya alam seperti tercemarnya air dan rusaknya lahan karena pertambangan akan berdampak besar pada kelangsungan hidup manusia dibumi ini. Pengelolaan sumber daya alam yang benar akan meningkatkan kesejahteraan umat manusia, dan sebaliknya pengelolaan sumber daya alam yang ceroboh akan berdampak buruk bagi lingkungan hidup. Oleh karena itu, persoalan mendasar sehubungan dengan pengelolan sumber daya alam adalah bagaimana mengelola sumber daya alam agar menghasilkan manfaat yang se- 
besar-besarnya bagi manusia, dan tidak mengorbankan lingkungan serta kelestarian sumber daya alam.

Pendayagunaan sumber daya alam yang kurang tepat mengakibatkan berbagai hal yang bisa merugikan manusia dan makhluk lainnya. Kerusakan lingkungan adalah salah satu akibat penyalahgunaan sumber daya alam yang tidak terarah dan tidak terkendalikan oleh manusia. Sumber daya alam yang melimpah membutuhkan pengelolaan dan pemanfaatan yang tidak merusak lingkungan. Caranya adalah dengan mengahlikan diri secara profesional dalam mengelola alam secara baik dengan mempertimbangkan gejala-gejala yang ditimbulkan.

Kaum Muslimin Sidang Jum'at, Rahimakumullah

Allah SWT. menciptakan alam dan isinya untuk manusia supaya bisa mengambil manfaat seluruh ciptaan-Nya karena tidak ada di alam ini yang sia-sia sebagaimana termaktub di dalam Al-Qur'an:

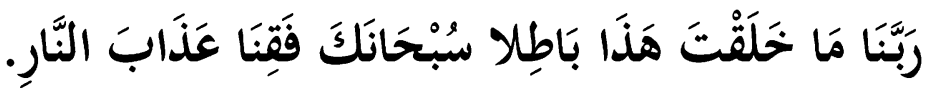

Artinya: "Ya Tuhan Kami, Tiadalah Engkau menciptakan ini dengan sia-sia, Maha suci Engkau, Maka peliharalah Kami dari siksa nera$k a^{\prime \prime}$. (QS. Ali-Imran [3]: 191)

Semua unsur yang ada di alam ini disebut lingkungan. Setiap unsur yang bisa diperoleh manfaat bagi manusia disebut sumber daya alam. Sumber daya alam bisa dimanfaatkan manusia untuk menopang kebutuhan hidup masnusia dan kelangsungannya. Manusia harus mampu mengelola dan menjaga kelestarian alam sesuai predikatnya sebagai khalifah di bumi sebagaimana disebut di dalam Al-Qur'an:

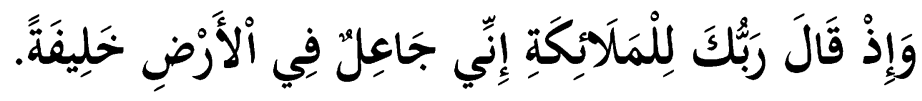


Artinya: "Ingatlah ketika Tuhanmu berfirman kepada para malaikat: "Sesungguhnya Aku hendak menjadikan khalifah di muka bumi". (QS. Al-Baqarah [2]: 30)

Arti khalifah di sini adalah manusia yang diberi kekuasaan dan kewenangan oleh Allah AWT. untuk mengelola. Mereka berkewajiban untuk mengelola alam ini agar membawa banyak manfaat bagi kehidupannya, dan bertanggung jawab atas segala yang terjadi. Pemanfaatan sumber daya alam harus dilakukan secara wajar dan tidak boleh berlebihan yang bisa menyebabkan kerusakan sebagaimana firman Allah SWt. di dalam surat Al-A'raf, Ayat 31:

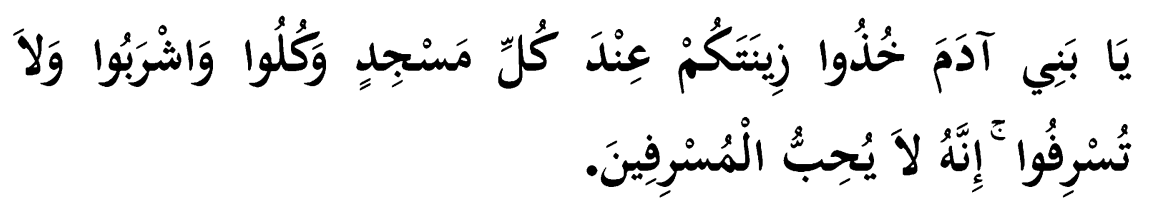

Artinya: "Hai keturunan Adam, pakailah pakaianmu yang indah setiap (memasuki) masjid, makan serta minumlah, dan janganlah berlebih-lebihan. Sesungguhnya Allah tidak menyukai orang-orang yang berlebih-lebihan". (QS. Al-A'raf [7]: 31)

Allah SWT. memerintahkan untuk mengenakan pakaian, makan dan minum, tetapi melarang semua itu dilakukan secara berlebihan. Melakukan sesuatu secara berlebihan berarti melampaui batas kewajaran. Inti ayat di atas adalah melarang memanfaatkan segala sesuatu secara berlebihan, termasuk mengelola dan memanfaatkan sumber daya alam. Dengan demikian menjadi jelas, bahwa pengelolaan dan pemanfaatan sumber daya alam juga dilarang berlebilhan dengan melakukan eksploitasi secara serakah dan tidak terkendali yang berakibat pada kerusakan dan bencana bagi kehidupan manusia.

Tindakan berlebihan dalam segala hal cenderung melanggar aturan yang benar dengan menghalalkan segala cara. Di berbagai belahan 
negeri ini, banyak dilakukan penebangan hutan tanpa disiapkan sebelumnya tanaman pengganti, penangkapan berbagai jenis satwa dengan beragam spesiesnya secara besar-besaran mengakhiri proses populasi, penangkapan ikan dengan bahan peledak membuat seluruh ikan mati, dan banyak contoh lainnya. Pemanfaatan sumber daya alam dengan cara-cara keserakahan itu telah menimbulkan banyak kerusakan tanpa mempertimbangkan kelestarian alam di masa depan untuk generasi mendatang.

Demikian khutbah kali ini, semoga ini bermanfaat dan bisa menjadi bahan renungan bagi kita semua.

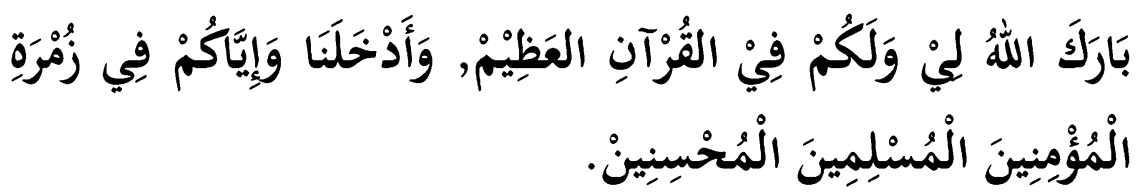




\section{Khuthbah 2}

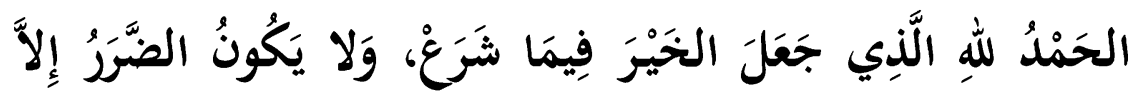

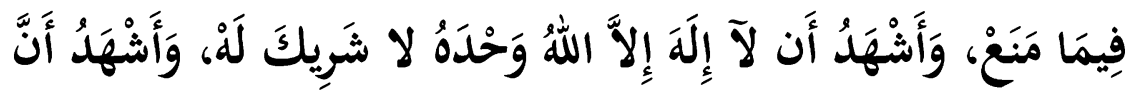

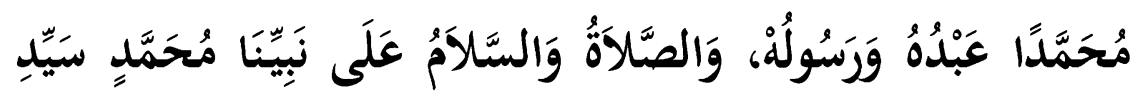

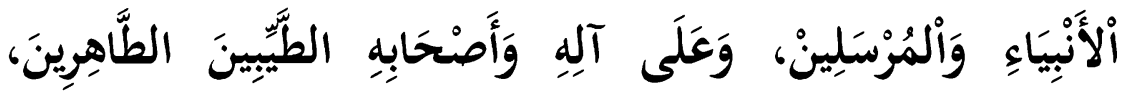

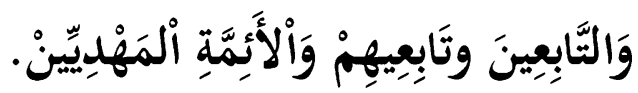

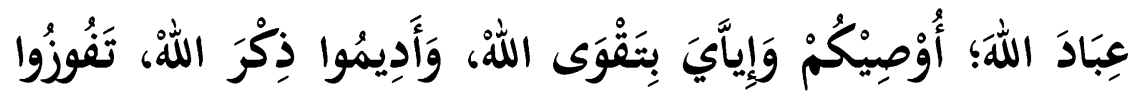

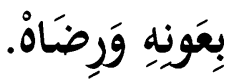

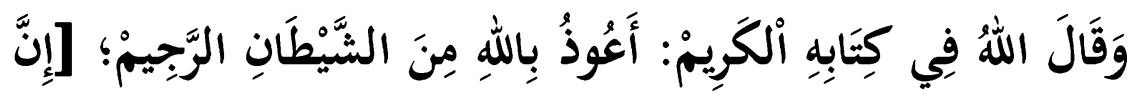

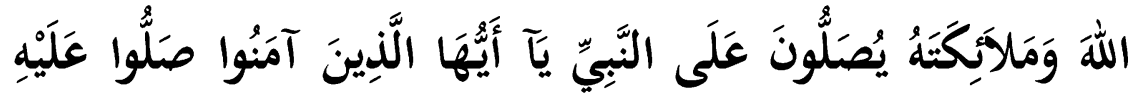

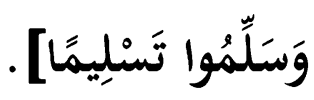

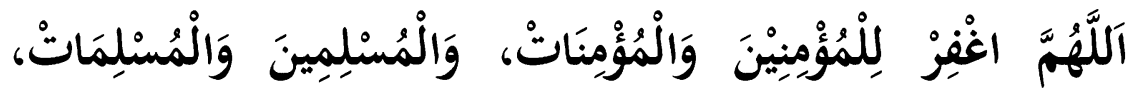

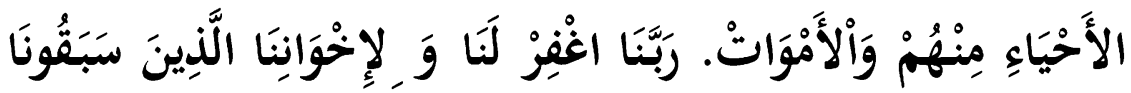

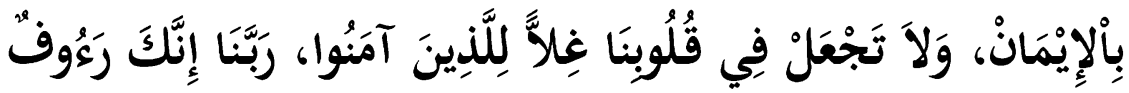

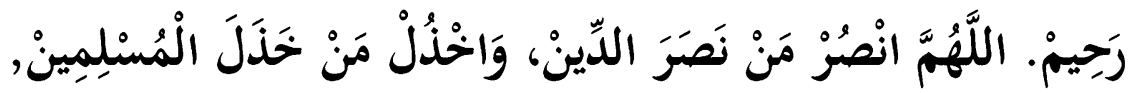

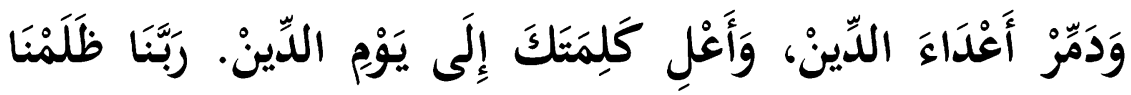




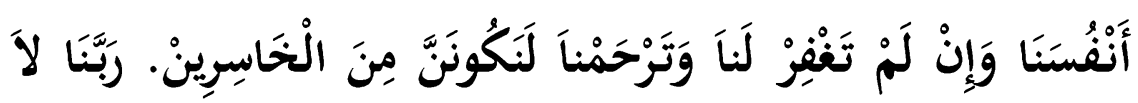

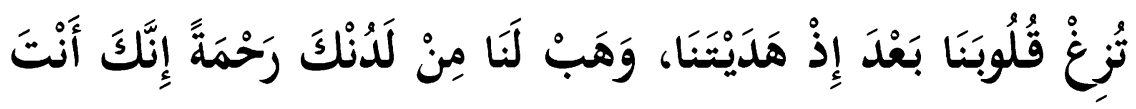

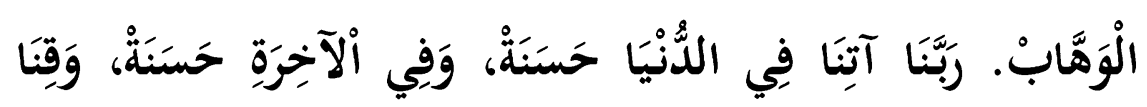

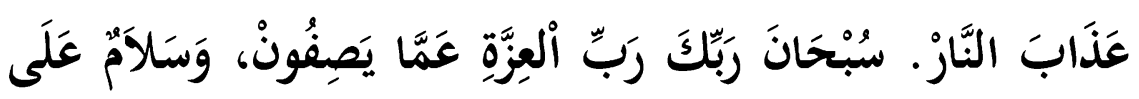

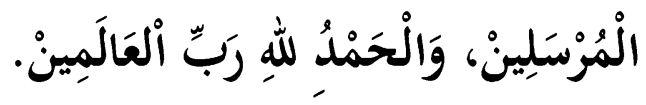

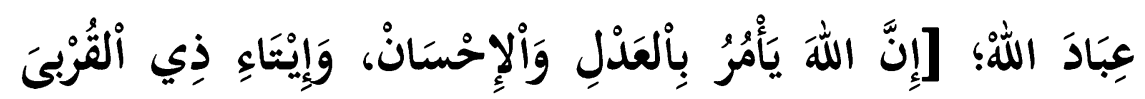

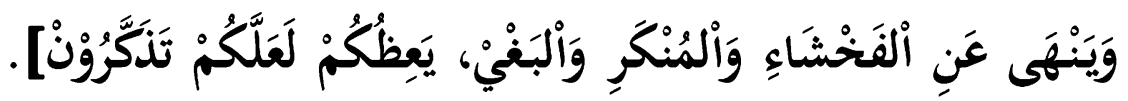

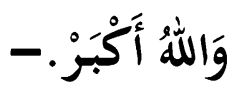






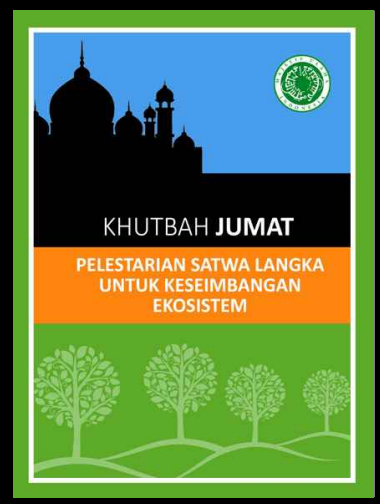

Kumpulan khutbah Jumat Tentang "Pelestarian Satwa Langka untuk Menjaga Keseimbangan Ekosistem" ini memberikan arahan bagaimana dan apa yang seharusnya dilakukan oleh manusia agar eksistensi satwa dapat terjaga untuk seterusnya. Punahnya satwa akan berdampak buruk secara langsung pada kehidupan manusia. Kumpulan khutbah Jumat ini juga memberikan petunjuk bagaimana sesungguhnya keindahan ajaran Islam yang mendorong umat manusia untuk berperilaku baik (al-ihsan) kepada satwa. Kumpulan khutbah Jumat ini layak untuk dibaca dan dijadikan referensi bagi para khathib dalam menyampaikan khutbahnya, dan bagi umat Islam, sehingga tumbuh kesadaran untuk menjaga dan melestarikan satwa.

- KH Dr. Ma'ruf Amin, Ketua Umum Majelis Ulama Indonesia.

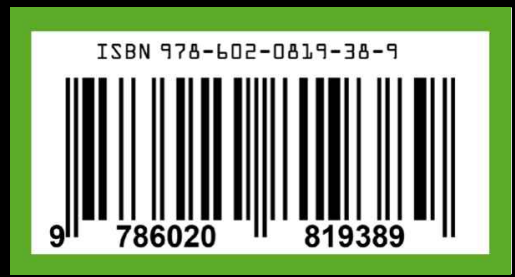

